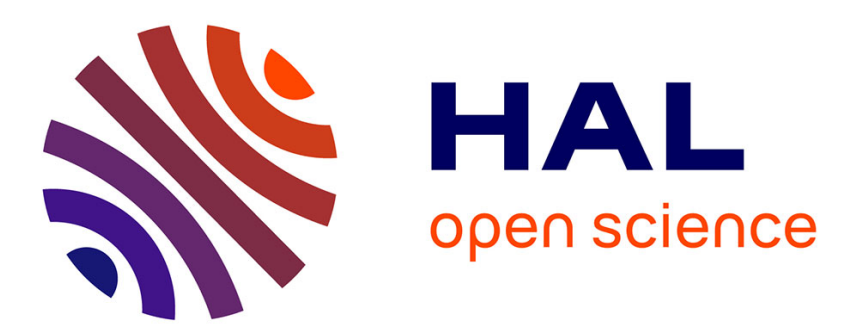

\title{
Global connections between aeolian dust, climate and ocean biogeochemistry at the present day and at the last glacial maximum
}

B A Maher, J M Prospero, D Mackie, D. Gaiero, P P Hesse, Yves Balkanski

\section{- To cite this version:}

B A Maher, J M Prospero, D Mackie, D. Gaiero, P P Hesse, et al.. Global connections between aeolian dust, climate and ocean biogeochemistry at the present day and at the last glacial maximum. Earth-Science Reviews, 2009, 99 (1-2), pp.61-97. 10.1016/j.earscirev.2009.12.001 . hal-02870475

\section{HAL Id: hal-02870475 https://hal.science/hal-02870475}

Submitted on 17 Jun 2020

HAL is a multi-disciplinary open access archive for the deposit and dissemination of scientific research documents, whether they are published or not. The documents may come from teaching and research institutions in France or abroad, or from public or private research centers.
L'archive ouverte pluridisciplinaire HAL, est destinée au dépôt et à la diffusion de documents scientifiques de niveau recherche, publiés ou non, émanant des établissements d'enseignement et de recherche français ou étrangers, des laboratoires publics ou privés. 
Global connections between aeolian dust, climate and ocean biogeochemistry at the present

2 day and at the last glacial maximum.

3

4 B. A. Maher ${ }^{\mathrm{a}^{*}}$, J.M. Prospero ${ }^{\mathrm{b}}$, D. Mackie ${ }^{\mathrm{c}}$, D. Gaiero ${ }^{\mathrm{d}}$, P.P. Hesse ${ }^{\mathrm{e}}$, Y. Balkanski $^{\mathrm{f}}$

5

$6{ }^{a}$ Centre for Environmental Magnetism \& Palaeomagnetism, Lancaster Environment Centre,

7 University of Lancaster, LA1 4YQ, UK

8

9 b Marine and Atmospheric Chemistry \& The Cooperative Institute for Marine and Atmospheric

10 Studies, Rosenstiel School of Marine and Atmospheric Science, University of Miami, 4600

11 Rickenbacker Causeway, Miami FL 33149, USA

c Department of Chemistry, University of Otago, Dunedin, New Zealand

${ }^{\mathrm{d}}$ Centro de Investigaciones Geoquímicas y Procesos de la Superficie, Facultad de Ciencias

16 Exactas Físicas y Naturales, Universidad Nacional de Córdoba, Avda. Vélez Sársfield 1611,

17 X5016CGA - Córdoba, Argentina

18

19 e Department of Environment and Geography, Macquarie University, NSW 2109, Sydney,

20 Australia

21

${ }^{f}$ Laboratoire des Sciences du Climat et de l'Environnement, l'Orme des Merisiers, 91191 Gif

23 sur Yvette Cedex, France.

*Corresponding author b.maher@lancs.ac.uk, tel. +44 1524 510268, fax +44 1524510269 


\section{Abstract}

Palaeo-dust records in sediments and ice cores show that wind-borne mineral aerosol ('dust') is strongly linked with climate state. During glacial climate stages, for example, the world was much dustier, with dust fluxes two to five times greater than in interglacial stages. However, the influence of dust on climate remains a poorly quantified and actively changing element of the Earth's climate system. Dust can influence climate directly, by the scattering and absorption of solar and terrestrial radiation, and indirectly, by modifying cloud properties. Dust transported to the oceans can also affect climate via ocean fertilization in those regions of the world's oceans where macronutrients like nitrate are abundant but primary production and nitrogen fixation are limited by iron scarcity. Dust containing iron, as fine-grained iron oxides/oxyhydroxides and/or within clay minerals, and other essential micronutrients (e.g. silica) may modulate the uptake of carbon in marine ecosystems and, in turn, the atmospheric concentration of $\mathrm{CO}_{2}$. Here, in order to critically examine past fluxes and possible climate impacts of dust in general and iron-bearing dust in particular, we consider present day sources and properties of dust, synthesise available records of dust deposition at the last glacial maximum (LGM); evaluate the evidence for changes in ocean palaeo-productivity associated with, and possibly caused by, changes in aeolian flux to the oceans at the LGM; and consider the radiative forcing effects of increased LGM dust loadings.

Keywords: aerosols, dust, climate change, palaeoclimatology, radiative forcing, iron fertilisation. 


\section{Introduction}

Palaeo-dust records show that wind-borne mineral aerosol (here referred to as 'dust') is strongly linked with climate state. Studies of dust in sediments and ice cores show that dust concentrations and fluxes have changed greatly in association with changes in climate, for example, in the transitions from glacial to interglacial regimes. During glacial climate stages, the world was much dustier, with dust fluxes two to five times greater than in interglacial stages (e.g. Kohfeld and Harrison, 2001). However, the influence of dust on climate remains a poorly quantified and actively changing element of the Earth's climate system. We know from presentday studies that dust can influence climate directly, by changing the radiative properties of the atmosphere through the scattering and absorption of solar and terrestrial radiation, and indirectly, by acting as ice nuclei (Sassen et al., 2003) and modifying cloud properties which, in turn, can impact both the radiative balance of the Earth and the hydrological cycle (Arimoto, 2001). Dust transported to the oceans can also affect climate indirectly, by supplying elements such as $\mathrm{Fe}$, an essential micronutrient in enzymes essential to photosynthesis (Martin et al., 1991); phytoplankton in about $40 \%$ of the world ocean are Fe-limited (Moore et al., 2002). Thus, dust delivery to the ocean can modulate the uptake of carbon in marine ecosystems and, in turn, the atmospheric concentration of $\mathrm{CO}_{2}$.

Dust not only can affect climate, but the generation and transport of dust is itself extremely sensitive to climate. At the present day, the most obvious link is with aridity - the globally dominant sources of dust are all located in arid or semi-arid regions. Global model estimates of present-day dust mobilization rates are poorly constrained, reflecting the scarcity of temporal and spatial data coverage, and range between $\sim 1$ and $3.5 \mathrm{Pg} \mathrm{yr}^{-1}$ (e.g. Tanaka and Chiba, 2006;

Zender et al., 2003; Engelstaedter et al., 2006); optimized multi-model estimates yield a range of 1.5 to $2.6 \mathrm{Pg}$ yr-1(Cakmur et al., 2006). Estimates of deposition to the oceans range from about 0.3 to $2 \mathrm{Pg} \mathrm{yr}^{-1}$ (Zender et al., 2004; Mahowald et al., 2005). Human activities can have an impact on dust mobilization but here too estimates are poorly constrained and range from 0 to 50 $\%$ of global dust emissions (e.g. Tegen et al., 2004; Mahowald et al., 2004; Yoshioka et al., 2005). 
As recorded in sediments and ice cores, there have been large and systematic variations in dust loading in the past. The large changes in dust emissions and transport seen from the palaeo-dust record may reflect a variety of processes: changes in sources and source conditions; changes in vegetative cover; sub-aerial erosion of emergent continental shelves; deflation from periglacial deposits; variations in wind speed and gustiness; changed wind patterns linking sources to deposition areas; changes in deposition along the dust transport path. In order to interpret the palaeo-record and to anticipate future changes in climate, we need to have a better understanding of the factors that affect dust mobilization and its subsequent climatic impacts.

The complex linkages between climate and the dust generation-transport process on glacialinterglacial time scales is illustrated in figure 1 . There are many processes that can affect the dust cycle either directly or indirectly under any specific climate scenario. The relative importance of any specific process can change dramatically when shifting from one climate state to another e.g., during glacial stages, low sea levels expose coastal sediments and glacial action can produce unvegetated, unconsolidated deposits all of which can become major sources of dust. A major driver in the Earth's climate system is atmospheric $\mathrm{CO}_{2}$. Figure 1 shows how dust transport to the oceans could conceivably modify ocean productivity and atmospheric $\mathrm{CO}_{2}$ and the consequent impacts on other climate variables including the dust cycle. One major objective of palaeoclimatology is to use the dust record in ice cores and sediments, coupled with our knowledge of Earth surface processes today, to improve our understanding of these linkages in the current climate state and to use this information to better interpret the Earth's past climate history.

For the future, dust cycle models predict large changes in aeolian transport from the continents to the oceans over coming centuries, in response to anthropogenic climate change (e.g. Mahowald et al., 2006). In order to anticipate the effects of future changes in dust emissions, it is important to identify the impacts of past and present-day dust flux changes in terms of feedbacks with regard to radiative forcing of dust aerosols and any ocean fertilization and resultant productivitydriven changes in atmospheric $\mathrm{CO}_{2}$. 
Here, in order to examine past fluxes and possible climate impacts of dust in general and ironbearing dust in particular, we synthesise available records of dust deposition at the last glacial maximum (LGM); evaluate the evidence for changes in ocean palaeo-productivity associated with, and possibly caused by, changes in aeolian flux to the oceans at the LGM; and consider the radiative forcing effects of increased LGM dust loadings. We begin by presenting an overview of global dust processes and the state of our knowledge about these processes.

\section{Figure 1}

\section{Present-Day Global Dust Processes and Distributions}

\subsection{Dust source processes.}

Dust mobilization is a highly complex process that is a function of many atmospheric, soil, and terrain properties (Goudie, 2008). Consequently the detachment, entrainment and transport of dust are highly variable both spatially and temporally. Dust generation is mostly associated with strong and/or gusty winds with the emitted flux varying as the third or fourth power of wind speed. The necessary wind fields to uplift dust can be generated by a wide range of local meteorological conditions. In particular, surface heat fluxes that induce convective activity can lead to dust generation (Engelstaedter and Washington, 2007) e.g., haboobs (Williams, 2008). Terrain features can strongly modulate emission rates (Washington et al., 2005; Koren et al., 2007). Particle detachment is inhibited by any element which increases surface roughness, e.g. vegetation, snow cover and surface armouring (by pebbles, stones or by salt crusts). Soil moisture plays a critical role by affecting particle cohesion along with cementation by salt content and soil structure. Dust emission thus tends to be favoured in arid or semi-arid areas, with annual rainfall $<\sim 250 \mathrm{~mm}$ p.a. (Prospero et al., 2002; Washington et al., 2003), little or no vegetation cover and strong, long-fetch winds.

Many of the most intense present-day dust sources are associated with deep alluvial deposits laid down in the Pleistocene and Holocene (Prospero et al., 2002). Direct detachment and entrainment by the wind of particles (especially fine particles, $<20 \mu \mathrm{m}, \mathrm{PM}_{20}$ ) appears subordinate to the effects of saltation (fig. 2); the impacts of sand-sized grains and/or aggregates on their downward trajectory cause 'sandblasting' - the emission of finer dust grains from the surface and/or from the original saltating aggregate (e.g. Gillette, 1978; Shao et al., 1993; Sow et
Deleted: ranging from synoptic-scale systems

Deleted: to smaller scale convective processes 
al., 2009). Thus the dust mobilization process and the resulting properties of the deflated dust can be extremely sensitive to a wide range of environmental variables (including, for example, land use change (Tegen et al., 1995)). The complexity of these processes potentially makes dust a good proxy for climate variability but also makes the dust record difficult to interpret.

Figure 2.

\subsection{Global dust sources and transport.}

Much of our knowledge of the large-scale transports of dust is based on remotely sensed data, primarily from satellites. While there is an extensive literature of the directly measured concentrations and physical properties of dust, these are mostly too isolated in time and space to provide a coherent picture of dust transports. However, such measurements, when coupled with remote sensing data, can provide a compelling and informative picture of global dust transport. Satellites have come to play a dominant role in aerosol research (Kaufman et al., 2002). At present there is a large variety of sensors and platforms that provide information on aerosol concentrations and on some aspects of their physical properties - e.g., size, radiative absorption, polarization (Dubovik et al, 2008) - and also on the altitude distribution of these properties (e.g., Liu et al., 2008).

Satellite measurements of aerosol optical depth (AOD) with NOAA Advanced Very High Resolution Radiometer (AVHRR) provide a global picture of aerosol transport over the oceans (Fig. 3a; Husar et al., 1997). Over land, the most active dust source regions are detected with the Total Ozone Mapping Spectrometer (TOMS) absorbing aerosol product (Fig. 3b; Prospero et al., 2002). More recently, Shepanski et al. (2007) identified the regions where dust source is activated using three different infrared channels of the Meteosat Second Generation (MSG) instrument. This analysis is based on the frequency of dust generation but does not allow to retrieve the magnitude of the flux resulting from the episodes. Analyzing dust emission flux or evaluating dust mass requires a careful analysis of dust optical depth retrieved over deserts by the MISR (Multiangle Imaging SpectroRadiometer) instrument, together with information on the vertical distribution of dust retrieved from CALIPSO (Cloud-Aerosol Lidar and Infrared 
the diurnal cycle of dust emissions over Western Africa. Sixty five percents of dust source activation was found to occur in early morning from 0600-0900 UTC, well before the hours when the surface latent heat fluxes become important.

It is clear from Figure 3 that at the present day the northern hemisphere is far more 'dusty' than the southern hemisphere. This statement is based largely on in situ aerosol measurements made in different ocean regions (e.g. Duce et al., 1991; Prospero, 1996a; Prospero et al., 1989) and on satellite products such as shown in Figure 3. Satellite AOD distributions (fig. 3a) show large areas of high AOD over the oceans; the distribution of these plume-like features is clearly linked to continental sources. The largest and most persistent plumes (fig. 3a) emanate from arid regions in North Africa, the Middle East and Asia; the aerosols in these plume regions typically contain high concentrations of dust (e.g., Husar et al., 1997; Duce et al., 1991; Prospero, 1996; Prospero et al., 1989). These plumes can be directly linked to dust sources on the continents using the TOMS satellite (fig. 3b), one of the few sensors that can effectively sense aerosols over land (Herman et al., 1997).

It is notable that the major source regions (Fig. 3a and b; Table 1) are concentrated within a broad 'dust belt' that extends from the west coast of North Africa eastward to the Pacific coast of China. The timing of maximum dust emissions varies across this dust belt. In North Africa, maximum dust transport occurs in boreal summer, with dust transported across the Mediterranean to Europe and the Middle East (Moulin et al., 1998) and across the Atlantic to the Caribbean (Prospero and Lamb, 2003), the southeastern United States (Perry et al., 1997;

Prospero, 1999), and the midlatitude western North Atlantic (Arimoto et al., 1995). There is also considerable transport in the winter with dust carried into South America (Prospero, 1981). In the Middle East, activity peaks in the late spring/summer and is at a minimum in the winter. Over the Indian subcontinent, activity peaks in the spring and decreases in the summer with the onset of the southwest monsoon. In Asia, dust activity peaks strongly in the boreal spring.

Of the major dust sources, North Africa is by far the strongest, contributing 40-60\% of global dust emissions (e.g. Prospero, 1996b; Ginoux, 2001). For example, the so-called Sahara-Sahel 'dust corridor' extends over $\sim 4000 \mathrm{~km}$ from Chad to Mauritania and emits very large volumes 
of dust over the Atlantic Ocean (Moreno et al., 2006). Within this broad 'corridor', specific sources stand out as 'hot spots' of activity. Most notable is the Bodele Depression, Chad, the world's most persistently intense dust source at present day, responsible for an estimated $\sim 15-20$ $\%$ of North African emissions (Washington et al., 2006). While the Bodele stands out as a unique source on a global scale, much of North Africa serves as an effective dust source. Indeed, much of North Africa is frequently covered by a dust pall during much of the year. A large region of intense and frequent dust activity lies in Mali, Mauritania and southern Algeria (Prospero et al., 2002; Goudie and Middleton, 2006). Many of the most active sources are associated with drainage systems from the Ahaggar Mountains. This region is probably more representative generally of arid region dust sources and source processes, with many types of sources contributing to the dust emissions: i.e., old alluvial deposits, playas, dried lakes and wadis. Another area of dust activity lies in Tunisia and Northeast Algeria, greatest activity occurring in association with an extensive system of salt lakes and dry lakes in the lowlands south of the Tell Atlas Mountains. Major dust activity also occurs in the eastern Libyan desert in a region marked with an interconnected a chain of wadis (Wadi al-Farigh, Wadi al Hamim). Other active sites are found in Egypt, Sudan and the flanks of the Ethiopian Highlands.

The other major source regions of the Northern Hemisphere are the Arabian peninsula ( 10-20 $\%$ of global emissions, Table 1) and central and eastern Asia ( 15-20\%). For the Arabian peninsula, two major active areas extend along the eastern side of the peninsula along the Persian Gulf, and along the Oman coastal margins (fig. 3), comprising coastal sabkhas and dissected wadi systems, respectively (Goudie and Middleton, 2006). The lower Tigris-Euphrates basin, from north of Baghdad to the Persian Gulf, also provides a summer peak in dust activity, sourced from an immense alluvial plain. Very high concentrations of dust and pollution-derived species are found over the Arabian Sea early in the year (fig. 3a) carried by the winter monsoon and the action of systems moving from the North (Verma et al., 2007). Dust is carried from sources in the eastern Sahara and in northwest India (including the Thar Desert) and Pakistan.

Concentrations of dust and pollutant species drop sharply across the inter-tropical convergence zone and with the onset of the southwest (summer) monsoon (Savoie et al., 1987; Krishnamurti et al., 1998) and demonstrate the effectiveness of the inter-tropical convergence zone in blocking the transport of aerosols to the southern hemisphere. 
In eastern Asia, dust sources - mostly in China - are extremely active in the boreal spring. Very large quantities of dust (often mixed with high concentrations of pollutants) are carried out of China eastward, across the coastal waters, and over Korea and Japan where the dust is such a persistent phenomenon, noted in many centuries of historical records, that it is given a name, 'kosa' - yellow dust (Kar and Takeuchi, 2004). Asian dust is routinely observed in relatively high concentrations at stations in the central North Pacific (Prospero et al., 1989). The strong seasonal dust cycle and the trans-Pacific extent of the transport can be seen in figure $3 \mathrm{a}$. Although there are many active dust sources in China (Prospero et al., 2002; Goudie and Middleton, 2006; Wang et al., 2004), several stand out in satellite images: the Tarim Pendi basin (containing the Taklimakan Desert; central Inner Mongolia Plateau and the Gobi Desert); the Hexi Corridor and the Loess Plateau; and western Inner Mongolian Plateau. The Tarim Pendi basin, which receives very little rainfall (50-100 $\mathrm{mm}$ a year along its periphery and $\sim 10 \mathrm{~mm}$ in the central regions), is most active from February through May. The Gobi desert, located east of the Tarim Basin on the Mongolian Plateau, is a major dust source at present. Every spring, spectacular dust storms can be seen generated over the Gobi; similar to many dust events in North Africa, the most active sources cover a relatively small area of the surface in effect acting as 'point' sources. Gobi dust outbreaks can be followed $\mathrm{n}$ satellite imagery as they move across the Pacific to North America (Husar et al., 2001). The Loess Plateau extends over $\sim 440,000 \mathrm{~km}^{2}$ and is covered with loess with depths ranging from typically $\sim 100 \mathrm{~m}$ to as much as $350 \mathrm{~m}$ (Maher et al., 2008). The Loess Plateau is unique in the global dust picture in that it is the only loess region that serves as a highly active dust source at the present day. These loessic soils are now susceptible to enhanced deflation because of the intense agricultural activity in this region (Wang et al., 2004). While various estimates exist as to the quantitative effects of human activities in dust mobilization (see Section 1), it is clear that of all the major dust sources, the Asian sources are those where humans could be having a major effect on emissions, although this is still a matter of considerable debate (Wang et al., 2006). 
For the southern hemisphere, contemporary dust sources have been mapped by Prospero et al. (2002) using TOMS data. Australia, South America and southern Africa each have localized areas of dust emissions. However, there is little evidence of major and sustained dust activity in these regions. Although there are few measurements of aerosols over the southern oceans, these show much lower concentrations than over the northern oceans (e.g., Prospero et al., 1989; Baker et al., 2006; Wagener et al., 2008). Measurements of AOD (e.g. Fig. 3a) made by a wide variety of satellite systems (Zhu et al., 2007) fail to detect substantial aerosol plume effects that can be attributed to dust sources. This may partly reflect some under-estimation by TOMS due to difficulties of dust detection in cloudy conditions (e.g. Gassó and Stein, 2007). However, compilations of satellite aerosol event imagery contain many hundreds of examples of dust plumes, the overwhelming majority of which are linked to Northern Hemisphere sources (see, for example: http://visibleearth.nasa.gov/; http://rapidfire.sci.gsfc.nasa.gov/gallery/). In stark contrast, model results (IPCC, 2001a; Li et al., 2008) often identify emission of large dust plumes from Australia (comparable to those sourced from NW Africa). Ground-truthing of either the remotely sensed or modelled data is severely constrained by the lack of modern dust data. For example, while the ModelE dust component of the GISS Global Circulation Model (Cakmur et al., 2006) is constrained by data from 96 individual sites, only 18 of those are in the southern hemisphere (and of these, 13 were measured during a historic low for dust emissions from Australia (Mackie et al., 2008). The main Australian source is the Lake Eyre basin (Bullard et al., 2008), followed by the Murray-Darling basin, both comprising extensive river systems, floodplains and dunefields (Bullard and McTainsh, 2003). There are two main dust transport paths, one to the northwest and one to the southeast (Bowler, 1976). Although the southeast path is often described as crossing the Tasman Sea (and Australian dust is often reported in New Zealand, e.g. Marx et al., 2005), individual events are variable and can contribute sediment further south, to the Southern Ocean and southwest Pacific (McGowan et al., 2000; McTainsh et al., 2005; Shao et al., 2007). Iron is a conspicuous component of Australian soils and dust storms (Taylor et al., 1983; McTainsh, 1989; Mackie et al., 2008) but the concentrations and mineralogy of Antipodean long range transport (LRT) dusts are poorly known. From magnetic measurements, modern dusts from eastern Australia and the palaeo-dust contained within Tasman Sea sediments contain fine-grained haematite/goethite, which varies directly with the concentration of the mineral dust fraction (Hesse, 1997). New Zealand appears to be an 
insignificant source of dust at the present day (Prospero et al, 2002), unsurprising as prevailing trans-Tasman winds are to the east (McGowan et al., 2000).

Although southern Africa has some significant dust sources (notably the Etosha, Namibia and Magkadikgadi, NE Botswana, pans; Prospero et al., 1992; Washington et al. 2003), it is not a major exporter of dust. Iron-rich South African dust that enters the ocean is largely ( $>90 \%)$ deposited in the S. Indian Ocean (e.g. Piketh et al., 2000) along latitude $\sim 35^{\circ} \mathrm{E}$ with only $\sim 4 \%$ entering the S. Atlantic (Garstang et al., 1996) Some work (Stuut et al. 2005) points to deflation of silt-rich $(>20 \mu \mathrm{m})$ dust to the southwest into the South Atlantic, but it is unknown if this is then transported into the higher latitudes.

For South America, the southern region is spanned by a continuous band of arid or semi-arid terrains extending from the Peruvian to the Patagonian coast (the 'Diagonal àrida'/arid diagonal). Based on TOMS data, Prospero et al. (2002) identified three main dust sources in southern S. America which overlap most of this arid diagonal: the Puna $\left(22-26^{\circ} \mathrm{S}\right) /$ Altiplano $\left(15-22^{\circ} \mathrm{S}\right)$ Plateau, central-west Argentina (27-35 $\left.{ }^{\circ} \mathrm{S}\right)$ and Patagonia $\left(39-52{ }^{\circ} \mathrm{S}\right)$. Preferential emission sources appear linked to large dry lakes (Puna/Altiplano), thousands of small enclosed basins (Patagonia) and extensive alluvial fans (central-west Argentina). Patagonia is strongly influenced by the southern hemisphere westerlies. Patagonian-sourced dust is estimated to supply $\sim 90 \%\left(\sim 30 \mathrm{~g} \mathrm{~m}^{-2} \mathrm{a}^{-1}\right)$ of the present day sediment flux to the SW Atlantic from S. America (Gaiero et al. 2003). In the high arid plateau (Puna/Altiplano) of the central Andes, the climate is mostly governed by the subtropical jet stream and dust emitted from this area can be directly injected into the tropospheric winds. Both wind systems can produce eastward dust transport and deposition to proximal areas like the Pampas and the nearby Atlantic Ocean or, distally, to the Southern Ocean or the East Antarctic Plateau. The characteristics of present day Patagonian dust are relatively well known (Gaiero et al., 2003; Gaiero et al., 2004; Gaiero et al., 2007). Clay-size fractions are dominated by the clay mineral, smectite. The chemical/isotopic composition of dust reflects the contribution of Jurassic and Quaternary explosive volcanism (Gaiero et al., 2007). Dust deposition rates vary from $\sim 5 \mathrm{~g} \mathrm{~m}^{-2} \mathrm{a}^{-1}$ at the Patagonian coast, $\sim 28 \mathrm{~g} \mathrm{~m}^{-2} \mathrm{a}^{-1}$ (Gaiero et al., in prep.) at the Central Pampa $\left(33^{\circ} \mathrm{S}\right)$; and $\sim 26 \mathrm{~g} \mathrm{~m}^{-2} \mathrm{a}^{-1}$ for the southern Pampa $\left(39^{\circ} \mathrm{S}\right)$ regions (Ramsperberger et al., 1998; Gaiero et al., 2003). 
Major dust sources require not only the operation of efficient dust deflation and transport processes but also a replenishment of dust supply, through active weathering and comminution of parent materials. TOMS (fig. 3b) shows a clear association of dust sources with specific types of terrains and environments. All major sources in figure $2 \mathrm{~b}$ are located in arid regions (annual rainfall $<\sim 200-250 \mathrm{~mm}$ ) and centered over topographical lows or on lands adjacent to strong topographical highs. Although the source regions themselves are arid or hyper-arid, fluvial action is evident everywhere by the presence of ephemeral rivers and streams, alluvial fans, playas, and saline lakes. Furthermore, even presently arid source areas have had a relatively recent pluvial history. The association of dust sources with water features is consistent with our understanding of the processes involved in the production of fine particles through weathering (Pye, 1989; Smalley et al., 2005). Fluvial and chemical weathering processes appear much more efficient in the production of small particles (i.e., particles $<\sim 10 \mu \mathrm{m}$ diameter) than are aeolian processes (i.e. grinding and impaction). Subsequently, through fluvial action, small particles are carried to depositional basins or alluvial plains where, after drying, they are subject to deflation by wind. Thus, precipitation totals and timing are important both in the (low-lying) area of emission and in any adjacent, dust-supplying highlands. TOMS shows a remarkably consistent association of dust sources with playas and associated terrain environments [Prospero et al., 2002], such as the alluvial fans that ring the basins in which the playas are found (Reheis et al., 1995). The playa is the ultimate receptacle of almost all the fine-grained sediments eroded within a basin over a geological time period, thus they are storehouses of fine, dry, unconsolidated (and thus winderodible) sediments often in amounts far in excess of production rates in the present climate. An important characteristic of other major dust sources is the presence of deep and extensive alluvial deposits. During pluvial phases, these basins were flooded and thick layers of sediment were deposited which are now exposed. Many of the most active TOMS sources were flooded during the Pleistocene - Holocene. The prime example is the Bodele Depression in Chad, the largest source of long-range dust in the world (Warren et al., 2007).

Thus, the most productive dust-source environments at the present day are the result of the complex interplay between climate, terrain and geological history. In order to understand the linkages between climate, dust production, and transport, we must understand in detail how these features interact. 
Over the past decade, global circulation models and chemical transport models have come to play an important role in understanding dust-climate relationships. At present, there are over a dozen models that simulate the dust cycle, represent its optical properties and predict dry and wet deposition over the global domain (Textor et al., 2006). However, the accuracy of global aerosol models is limited by uncertainties in aerosol emission source characteristics, in our knowledge of atmospheric transport and removal processes and also errors in the meteorological data assimilated into the model computations. Thus there can be large differences among the outputs of the various models and, in the absence of aerosol measurements over large areas of the Earth, it is difficult to select the "best" model. Regardless of these shortcomings, most of the currently reported dust budget values are based on transport models (e.g. Werner et al., 2002; Luo et al., 2003; Zender et al., 2003 and 2004; Ginoux et al., 2004; Mahowald et al., 2005; Cakmur et al., 2006; Miller et al., 2006; Tanaka and Chiba, 2006; Li et al., 2008).

\section{Dust impacts on climate.}

\subsection{Dust as a source of bioavailable iron}

Dust may play a critical, indirect role in climate change, through biogeochemical interactions (e.g. via iron or other essential element fertilization of ocean and/or terrestrial ecosystems) and chemical interactions with ozone and sulphur cycles (Cwiertny et al., 2008; Chin et al., 2000). In the case of ocean fertilization, dust containing iron, as fine-grained iron oxides/oxyhydroxides and/or within clay minerals, and other essential micronutrients (e.g. silica) may play a significant role for those regions of the world's oceans where macronutrients like nitrate are abundant but primary production and nitrogen fixation is limited by iron scarcity. Hence, as formalised by Martin et al. (1990, 1991), the efficiency of the 'biological pump' is low and there is significant potential for enhanced export production and drawdown of atmospheric $\mathrm{CO}_{2}$. The Southern Ocean and the equatorial and northwestern subarctic Pacific are the major high nitrate, low chlorophyll (HNLC) areas, totalling some 30-50 \% of the world ocean (Moore et al., 2004; Aumont et al., 2003). Diatoms are the key phytoplankton group for formation of algal blooms in such areas and are strongly iron-limited. Additionally, in tropical and subtropical regions, iron deficiency may also limit phytoplankton growth in subtropical gyres (Johnson et al., 1997; Sedwick et al., 2005) and nitrogen fixation by the diazotrophs (Falkowski, 1997; Moore et al., 2006). Supply of iron-bearing dust may thus directly and indirectly limit primary productivity for 
large portions of the world ocean (Moore and Doney, 2007), affecting biological carbon export at the global scale (Moore and Braucher, 2008).

Consistently higher dissolved iron concentrations ( $>1 \mathrm{nM})$ are observed for ocean areas below major dust plumes (Sarthou et al., 2003). The 'iron hypothesis' (Martin, 1990) suggests that past increases in aeolian, iron-bearing dust supply to the surface of HNLC ocean waters during glacial stages relieved iron limitation on primary productivity. The resultant increase in the export of biogenic carbon from surface to deep ocean waters (the 'biological pump') caused a decrease in surface ocean $p \mathrm{CO}_{2}$ that was balanced by an increased drawdown of $\mathrm{CO}_{2}$ from the atmosphere. The details of this process, and the possible magnitude of its effects on the global carbon cycle, are the subject of much international debate (e.g. Honda et al., 2006; Maher and Dennis, 2001; Moore and Doney, 2007).

The sensitivity of HNLC regions to increased iron supply has been demonstrated by a series of artificial mesoscale iron fertilization experiments in the HNLC regions (e.g. Boyd et al., 2007; Coale et al., 2004; Coale et al., 1996). The common outcomes to these experiments were the expansion of phytoplankton standing stocks, with distinct population shifts to large diatom species, and resultant drawdown in atmospheric $\mathrm{CO}_{2}$ (deBaar et al., 2008; Tsuda et al., 2003). It has been difficult to quantify export production via subsurface storage of carbon (rather than subsequent re-release from the ocean mixed layer). For the NW Pacific SEEDS experiment, drawdown of atmospheric carbon was estimated at $\sim 150-1500 \mathrm{C}$ atoms per iron atom added (Tsuda et al., 2003). The most recent experiment was also the largest (Lohafex, 2009), with 6 tonnes of dissolved iron added to a $300 \mathrm{~km}^{2}$ ocean patch in the southwest Atlantic sector of the Southern Ocean. However, whilst there was a doubling of (non-diatom) phytoplankton biomass within the first two weeks, increased grazing pressure of zooplankton prevented further development of the algal bloom, with only minor amounts of carbon being removed from the ocean surface layer as a result.

Based on these magnitudes of export production, and taking into account the rather low fractions of iron estimated to be bioavailable from mineral dust (e.g. Baker et al., 2006a), modelled glacial-stage changes in atmospheric $\mathrm{CO}_{2}$ resulting from dust-driven iron fertilisation range from 
$\sim 20 \%$ (Bopp et al., 2003) to $>50 \%$ (Watson et al., 2000) of the total interglacial-glacial change of $\sim 100 \mathrm{ppmv}$. However, extrapolation of the artificial iron enrichment experiments to estimate past carbon sequestration may be unrealistic given their short duration and use of unfeasibly large and rapid iron additions, which lead to loss of most (80-95\%) of the iron added during the enrichment experiments (Bowie et al., 2001). More realistic estimates of carbon sequestration may be derived from analysis of a recent (Nov. 2004 - Feb. 2005), natural phytoplankton bloom in the Southern Ocean (Blain et al., 2007). This natural event was driven by indirect iron supply from upwelling of bottom waters (Lefevre and Watson, 1999; Maher and Dennis, 2001), rather than direct aeolian iron supply. $p \mathrm{CO}_{2}$ measurements of the surface waters showed that the bloom was an important $\mathrm{CO}_{2}$ sink, with mean $p \mathrm{CO}_{2}$ drawdown 2-3 x higher than that observed for the artificial Southern Ocean iron experiments, probably reflecting the longer duration of the natural bloom. Carbon sequestration efficiency was estimated to be at least 10 times higher than that estimated from the artificial experiments. The higher sequestration efficiency of the natural bloom has been attributed to its more complete and longer-lasting development, aided by slow and continuous natural additions of iron (and eventually other required macro-nutrients), from adjacent deep water supply (Blain et al., 2007). These results indicate first that aeolian supply of iron to the oceans, both directly and indirectly (i.e. deposited elsewhere and subsequently dissolved and transported), may have been significant in palaeo-ocean and atmospheric $\mathrm{CO}_{2}$ changes. Second, the HNLC oceans may presently be, and previously have been, more sensitive to aeolian iron supply than has been indicated to date by the artificial experiments. However, the SOIREE experiment (Boyd and Abraham, 2001) showed that the photosynthetic competency of iron-limited Southern Ocean phytoplankton increased only when the concentration of dissolved iron exceeded a threshold value of $\sim 0.2 \mathrm{nM}$, i.e. $\sim 2 \mathrm{x}$ twice the ambient $[\mathrm{Fe}]_{\text {dissolved }}$ value. Deposition of dust can thus increase the iron inventory of surface waters without stimulating a phytoplankton bloom (Boyd et al., 2009). Previous reports of correlation between dust events and remotely observed increases in surface water chlorophyll (e.g. Gabric et al., 2002; Shaw et al., 2008) need to be evaluated with respect to a physiologically realistic lag time between the increase in dust/iron supply and phytoplankton response (Boyd et al., 2004). For example, whilst Shaw et al. (2008) attributed a bloom in waters of the Great Barrier Reef Lagoon ( $<50 \mathrm{~km}$ from mainland) coastal to a large dust storm (the largest in over 40 years), Mackie (2009) pointed out that the time ( $<<1$ day) between dust deposition and observations of 
chlorophyll increase precluded dust as a causal agent. In response, Shaw et al. (2009) suggested that smaller dust events before the large dust storm were responsible. However, in waters so close to the coast, subject to numerous such small dust events, it is unlikely that iron limitation would develop in any case.

An assumption of many of the dust-cycle and iron supply models is that atmospheric input of bioavailable iron to the surface ocean varies linearly with dust loading. Present day field collection and dust leaching studies (Sedwick et al., 2007; Baker \& Jickells, 2006; Jickells et al., 2005 ) indicate that it is critical to identify the nature (mineralogy), source (e.g. size distribution) and transport history of the dust, in order to evaluate the possible proportion of bioavailable iron carried within the terrigenous dust loading (Baker and Jickells, 2006; Baker and Croot, 2009). A diverse range of dissolution experiments has been reported for a range of iron-bearing aluminosilicates and iron oxides (e.g. Journet et al., 2008), potential source soils (e.g. Visser et al., 2003) and increasing numbers of natural dust samples (e.g. Spokes et al., 1994; Baker et al., 2006b; Desboeufs et al., 2005; Mackie et al., 2005). Generally low but spatially variable iron solubilities appear the norm, i.e. $<0.6 \%$ (e.g. Baker et al., 2006b; Journet et al., 2008). At or close to source areas, soil mineralogy appears to be the key influence on iron solubility. For example, for some African sources, higher solubilities ( $0.3 \%)$ were displayed by iron-bearing, smectite-rich dust from the central Sahara and lower values $(0.1 \%)$ by illite/haematite/goethiterich dust from the western Sahara and the Sahel (Journet et al., 2008). Conversely, at areas remote from major dust sources, and associated with decreased dust concentrations, increased levels of iron solubility have been reported, and ascribed to progressive particle fining with long range transport (e.g. Baker and Croot, 2009). However, as discussed below, the particle size of LRT dust appears to stabilise rather than become progressively finer. Other factors of likely significance for iron solubility include enhancement of fine particle reactivity during the transport process, especially related to ligand formation and surface adsorption and/or desorption processes. Depending on ambient $\mathrm{pH}$, iron-hydroxyl groups at iron oxide surfaces can achieve negative surface charge by dissociation $\left(\mathrm{Fe}-\mathrm{OH} \rightarrow \mathrm{FeO}^{-}+\mathrm{H}^{+}\right)$or association $\left(\mathrm{FeOH}+\mathrm{H}^{+} \rightarrow\right.$ $\mathrm{FeOH}^{2+}$ ) of protons (e.g. Cornell and Schwertmann, 2003; Taylor et al., 1983). For the iron oxides/ hydroxides, the zero point of charge (zpc, i.e. where there are equal concentrations of surface $\mathrm{FeO}^{-}$and $\mathrm{FeOH}^{2+}$ ) varies between $\sim \mathrm{pH} 5$ - 8. Similar $\mathrm{pH}$-dependence of surface and 
inter-layer charge is displayed by the clay minerals, but with much lower zpc values, from $<\mathrm{pH}$ 2-3 for smectite to $\mathrm{pH} 2-4.5$ for kaolinite. Below the zpc, negatively-charged adsorbates, such as natural organic matter, can subsequently be retained at or near the mineral surface. Such adsorption may play a key role both in reducing particle scavenging and increasing iron solubility in the marine environment. Iron reduction can result from photolysis of $\mathrm{Fe}^{3+}$ complexed with bacterially-produced siderophores (Barbeau et al., 2001) complexes. The solubilised $\mathrm{Fe}^{2+}$ could then undergo direct biological uptake, be re-oxidised to $\mathrm{Fe}^{3+}$ and/or subjected to subsequent complexation. Recent reports suggest that Fe-reducing compounds, such as dimethyl sulphide, might interactively be released from iron-deficient phytoplankton (Johansen and Key, 2006), although the iron compound modelled in this study was ferrihydrite, the most microcrystalline and reactive of the soil oxyhydroxides. It is clear that large uncertainties presently remain regarding the biogeochemistry of iron complexation, release, uptake and scavenging in the marine environment (Baker and Croot, 2009).

The interpretation of Fe solubility in aerosol samples is complicated at the present day by the possible presence of Fe derived from anthropogenic sources, in particular, combustion processes, both industrial and biomass burning. Measurements on Bermuda (Sedwick et al., 2007) show that air masses from North American air typically contain relatively low concentration of aerosol iron $\left(0.5 \mathrm{nmol} \mathrm{Fe} \mathrm{m}^{-3}\right)$ but the fractional solubility is very high, $19 \%$. In contrast dust-laden African air masses contained relatively high concentrations of aerosol iron $\left(27.8 \mathrm{nmol} \mathrm{Fe} \mathrm{m}^{-3}\right)$ but the fractional solubility was low, only $0.44 \%$. The net result is that the quantity of soluble $\mathrm{Fe}$ derived from the aerosols was the same in both cases. The finest particle size fraction yielded the highest solubility for both aerosol types. Model results (Luo et al., 2008) suggest that combustion-derived iron can account for as much as $50 \%$ of the total iron deposited in some regions. However, over the open ocean it is usually less than $5 \%$ of the total iron although close to the East Asian continent in the North Pacific values can be as high as $30 \%$.

The observation of increased iron solubility associated with low dust concentrations would imply proportionally enhanced supply of bioavailable iron to ocean areas distal from dust sources (notably, the Southern Ocean) and less to high dust flux areas (Baker and Croot, 2009). The nature of the causal link between dust concentration and solubility requires further evaluation, in 
order for robust incorporation of varying values of iron solubility of dust into global models of iron flux (e.g. Fung et al., 2000; Bopp et al., 2003). Most models for dust-iron processes use a single uniform value for iron solubility from dust but a recent report of 2-3\% solubility of iron from glacial flour compared to $<1 \%$ for arid soils (Schroth et al., 2009) provides a new variable for models to incorporate. The impacts of ocean acidification, likely to modify aerosol and iron solubilisation processes, also require evaluation (Breitbarth et al., 2009).

\subsection{Dust impacts on climate: radiative effects.}

\subsubsection{Dust particle size}

Dust size distributions in ocean sediments and ice cores are often used as a measure of dust generation and transport dynamics. The size distributions of dust particles also have a critical influence on the direct and indirect climate impact of dust (see below) and they are also a major uncertainty in dust modelling. Most of the long-traveled dust mass is located in the size range under about $20 \mu \mathrm{m}$ diameter (e.g. Arimoto et al., 1997), with a mass median diameter of $\sim 1.5-$ $3 \mu \mathrm{m}$ (Balkanski et al., 1995; Reid et al., 2003). Particles in this size range can remain suspended in the troposphere for days to weeks, and be carried over great distances ( $>1000 \mathrm{~km})$ before being removed from the atmosphere by deposition processes. Asian dust, for example, has been shown to contribute to dust samples spanning western to eastern China (Gao et al., 1992), the Yellow Sea (Gao et al., 1997), Japan and Korea (e.g. Park et al., 2005), the Pacific Ocean (e.g. Duce et al., 1980; Rea et al., 1985; Uematsu et al., 1985). More distally, it has a significant impact on air quality in the western United States (VanCurren and Cahill, 2002); and is a major source of dust in Greenland ice cores (Bory et al., 2003). North African dust is carried in great quantities to the Amazon basin (Swap et al., 1992), into the Caribbean (Prospero and Lamb, 2003) and the southeastern (Prospero, 1999), eastern and northeastern US (Perry et al., 1997). The first challenge for improving data on dust particle size distributions, whether at present day or for the palaeo-record, is the need for expanded geographic and temporal coverage. The second requires instrumental convergence. Across the modern and palaeo-data aerosol communities, particle size tends to be measured using different instruments. For ice and sediment cores, for example, particle size analyses are most frequently derived from instruments using the Coulter Principle (such as the Coulter Multisizer). In contrast, the atmospheric community uses a wide range of instruments that are based on different physical principles, i.e., the mobility of aerosols 
in electric fields, the optical properties of aerosols, aerosol aerodynamic properties. These instruments yield widely disparate results even when making measurements on identical dust aerosol populations, including African dust (e.g. Reid et al., 2003).

Notwithstanding this instrumental caveat, modern aerosol size data suggest evolution of the modal diameters for long range transport (LRT, i.e. $>1000 \mathrm{~km}$ ) dust to a rather invariant range of $\sim 3$ to $3.5 \mu \mathrm{m}$ diameter, in contrast to values obtained in or near source regions, which tend to cluster at $\sim 5 \mu \mathrm{m}$ diameter (Sviridenkov et al., 1993; Arimoto et al., 1997, Moore et al., 2004; Maring et al., 2003). For example, dust measured on the Canary Islands (300 km from the N. African coast) and in Puerto Rico (5000 km to the west) shows very similar particle size distributions for the $<7 \mu \mathrm{m}$ size range (fig. $4 \mathrm{a}$ ). Larger particles ( $>\sim 7-8 \mu \mathrm{m}$ diameter) do display between-event differences, due to their preferential removal during atmospheric transport.

Similarly, in surface sediments along a $3600 \mathrm{~km}$-long, west-east transect of the North Pacific, a transect lying $\sim 4000-8000 \mathrm{~km}$ downwind from the E. Asian source areas (i.e. distal from any possible non-aeolian terrigenous sources), the median dust grain size barely changes, at $\sim 2.8 \mu \mathrm{m}$ to $2.4 \mu \mathrm{m}$ (Janecek, 1985). More recent atmospheric sampling campaigns also suggest a size range of $\sim 1-3 \mu \mathrm{m}$ for LRT particles in this region (e.g. Zhao et al., 2003). A simple empirical model, which sets the vertical velocity of dust particles equal to the Stokes gravitational settling velocity minus an upward velocity of $\sim 0.33 \mathrm{~cm} \mathrm{~s}^{-1}$, accurately predicts changes in dust size distribution during atmospheric transport (Maring et al., 2003). Thus it appears that some atmospheric process or processes partially counteract gravitational settling along long transport pathways. It should also be noted that the transport of giant, $>75 \mu \mathrm{m}$, grains of dust for up to 10,000 km has been reported (e.g. Pitty, 1968; Betzer et al., 1988, Middleton et al., 2001) and can not be explained in terms of simple Stokes type settling. The presence of long-lived, longtravelled dust concentrations within the atmosphere remains an unresolved challenge to our understanding of LRT processes.

Such relative observed invariance of dust size also suggests some degree of constancy in dust mineralogy, morphology and size at the regional scale (e.g. fig. 4a), in turn indicating that source 
soils or sediments are a factor in controlling dust particle size, in addition to wind speed and/or in-transport processing (Grini and Zender, 2004). In this scenario, dust properties remain consistent when the sources also remain constant, but can be expected to change if and when the source areas change. Wang et al. (2007) report similar conclusions for modern dusts sourced from NW China. The dust grain size distributions vary from source to source but are generally trimodal, with the first peak for particles $>11 \mu \mathrm{m}$, the second for particles $4.7-7 \mu \mathrm{m}$, the third for sub-micrometre particles $(<0.43 \mu \mathrm{m})$. These distributions remain essentially the same for any one source whether under dust storm or non-dust storm conditions. As noted by Wake and Mayewski (1994), distinctive variations have been observed in the particle number- and masssize distributions of dusts collected from different geographic regions, including Europe (e.g. Junge, 1963), the Sahara (Schutz and Jaenicke, 1974), the Swiss Alps (Wagenbach and Geis, 1987), Colorado and Texas (Patterson and Gillette, 1976), Tajikistan (Gomes and Gillette, 1993) and Greenland (Steffensen, 1985, 1997).

These observational data do not support the wind speed dependence of LRT dust particle size (fig. 4b) reported experimentally by Alfaro et al. (1998) and by observation by Sow et al. (2009). These studies indicate enhancement of very fine $(<2 \mu \mathrm{m})$ particles with increased wind speeds and surface shear velocity $\left(\mathrm{u}^{*}\right)$, as a result of 'sandblasting' by saltating grains. Within an erosional event, however, the dust size distribution appears relatively insensitive to measured changes of $\mathrm{u}^{*}$. This apparent conflict may reflect a dissonance between the typically long $\mathrm{u}^{*}$ averaging time (15 mins) and significantly shorter response times of the dust emission processes (Sow et al., 2009). Engelstaedter et al. (2007), in contrast, use AERONET data to support the conventional view that larger particle sizes reflect stronger, or possibly gustier, winds.

Figure 4.

\subsubsection{Dust radiative properties: effective particle size and mineralogy.}

In terms of radiative effects (RE), atmospheric dust can both scatter and absorb incoming solar and outgoing long-wave radiation (direct RE), which alters the energy balance of the atmosphere (IPCC 2001b; IPCC 2007), and can in turn produce changes in atmospheric circulation (Miller and Tegen, 1998) and cloud cover (Perlwitz and Miller, 2009). The effect of dust absorptivity is to produce warming of the atmosphere, locally or regionally, and cooling of the surface. The 
effect of scattering is to produce more widespread cooling, the result of increased upwards radiance. Dust also plays an important role in cloud microphysics, particularly with regard to numbers of cloud condensation and ice nuclei, thus influencing the formation and lifetime of clouds (indirect RE), which in turn influences the planetary albedo (e.g. Spracklen et al., 2008). Estimates from dust-cycle models of the net top of atmosphere direct RE currently span both negative and positive values, ranging from -0.6 to $+0.4 \mathrm{Wm}^{-2}$ (IPCC 2007). This uncertainty in both sign and amplitude of dust radiative forcing at the present day reflects both the complexity of dust distribution (including its vertical distribution, interaction with clouds, the albedo of the underlying surface) and poor understanding of the scattering/absorptivity of dust particles, in turn related to poorly known dust concentrations, mineralogy, particle size, and shape (e.g. Nousiainen, 2009). These latter properties vary regionally, depending on the source materials (soils, dry lake beds, ephemeral channels etc); and for any population of grains within a parcel of entrained dust, they also vary interdependently. Mineral dusts typically consist of an internal mixture of mineral species (and particle morphologies), often including quartz, clay minerals, iron oxides and calcium carbonate (Claquin et al., 1999), each with their own optical properties (Sokolik and Toon, 1999). Platy clay mineral particles, for example have different optical properties than equidimensional silicates (Nousiainen et al., 2009). Recent estimates in radiative forcing computations indicate that assuming that dust particles are homogenous spheres causes roughly as large an error as that associated with the uncertainties in refractive index (Kahnert et al., 2007). The latter has previously been considered the dominant source of uncertainty in dust optical properties. The radiative behaviour of dust particles also depends on their effective particle size, i.e. in relation to the wavelength under consideration. Thus, particles with diameters of around $0.5-1 \mu \mathrm{m}$ are effective in scattering solar radiation (fig. 5), relatively unaffected by particle shape or surface roughness effects. Such effects become increasingly important for wavelength-scale and larger particles (Nousiainen, 2009), including therefore those within the 1.5 - $3 \mu \mathrm{m}$ size range (i.e. the reported mass median diameter for LRT dust, as above).

\section{Figure 5}

Another poorly quantified potential control on dust absorptivity is the presence of iron oxides/ oxyhydroxides, as so-called 'free iron', i.e. often as discrete, sub-micrometre particles (figure 6), or as surface coatings on quartz grains, and, more rarely, iron oxide-clay aggregates (Sokolik and 
Toon, 1999). Only where soil $\mathrm{pH}$ is low will iron oxide grains carry sufficient positive charge, and/or the clay particles carry sufficient negative charge, to interact with each other (Cornell and Schwertmann, 2003).

Figure 6.

Haematite and goethite occur as minor soil components ( $<\sim 5 \%$ by mass) on a global scale, reflecting the near-surface weathering of $\mathrm{Fe}^{2+}$-containing primary (lithogenic) minerals by hydrolysis and oxidation. Given that they occur in minor concentrations, both these minerals have a disproportionate radiative impact, displaying large absorbing potential at shorter wavelengths (Alfaro et al., 2004; Sokolik and Toon, 1999; Balkanski et al., 1997). The mineralogy and concentration of iron oxides in dusts is dominantly controlled by the source soil hydrology and mineralogy (Schwertmann and Taylor, 1977), subsequently by any erosional processes of grain aggregation and/or disaggregation, and finally, by any particle size changes during transport (e.g. Zhang et al., 2005). Establishing mineralogical linkages between potential sources and airborne dust is likely to be most robust when based on particle size-specific comparisons between the clay and fine silt fractions of source soils/ sediments and the fine and coarse mode of sampled dust (Maher et al., 2009; Sokolik and Toon, 1999). Compared with its 'parent' soil, dust is likely to be biased towards smaller, less dense, and flatter (large surfacearea-to-volume ratio) particles (Nousiainen, 2009). Haematite and goethite tend to be associated with fine $(<<10 \mu \mathrm{m}$, i.e. fine silt and clay-sized) particles, with long residence times (i.e. days) in the atmosphere and thus potentially long transport paths.

Haematite has been identified as a significant absorber in terms of dust radiative properties (especially when present as sub-micrometre grains, fig. $6 \mathrm{~b}$ and c). It is very stable, is the end product of the dehydroxylation of all iron oxyhydroxides and is thus prevalent in warmer and drier regions and increasingly limited in occurrence pole-wards of latitudes $\sim 40^{\circ} \mathrm{N}$ and $\mathrm{S}$ (Cornell and Scherwtmann, 2003). For modern dusts from arid and semi-arid regions (Claquin et al., 1999), haematite content varies between 0.6 to $3.4 \%$ (by volume). The iron oxyhydroxide, goethite, is less restricted in its distribution. Although the red coloration of many soils and dusts often reflects the presence of haematite (highly pigmenting when it occurs as sub-micrometre grains), goethite is often volumetrically the more important. In the loess and palaeosols of the 
Chinese Loess Plateau, for example, the wt \% of goethite is $2-3 \mathrm{x}$ higher that of haematite (Balsam at al., 2007; Ji et al., 2004). Similar dominance of goethite has been reported for a limited number of dust source samples from the Sahara and the Sahel (Lafon et al., 2006). The presence of goethite can lead to large differences in the wavelength dependence of the single scattering albedo (Sokolik and Toon, 1999). The evenness of distribution of goethite in the soil matrix and resultant dusts is also likely to maximize its absorptivity. Inclusion of goethite in dust modelling thus seems essential, given its near-ubiquity in source soils.

Direct RE forcing by dust appears to result in cooling over much of the Earth's surface (fig. 7, and e.g. Perlwitz et al., 2001; Zhu et al., 2007). Conversely, over bright surfaces (such as deserts), dust can exert significant warming effects. For example, discrepancies between measured and modelled outgoing radiation over cloud-free, desert areas of north Africa indicate that dust may exert a long wave radiation forcing as great as $50 \mathrm{Wm}^{-2}$ in the monthly mean at 1200 U TC (Haywood et al., 2005). Similarly, for the 'great Indian desert' (Thar) area, warming of the lower atmosphere from dust absorptivity (greatest during the winter season) has been estimated at $0.7-1.2 \mathrm{~K} \mathrm{day}^{-1}$ (Moorthy et al., 2007). Due to direct and indirect RE, dust can regulate and interact with the heat sources and sinks of monsoonal regions, altering the monsoonal water budget (Lau and Kim, 2006). A further complication arises from increased emissions of anthropogenic, carbonaceous aerosols, which have reduced the global annual average single scattering albedo; aerosol at present day is estimated to be approximately twice as absorbing as that in preindustrial conditions (Myhre, 2009).

Given the potential impacts of effective particle size and iron mineralogy, improved modelling of dust optical properties at solar wavelengths can only be achieved with improved data on present and past regional variations in aerosol size and shape distributions, and in iron oxide concentrations, mineralogies and mixing state. Given that haematite and goethite occur mostly in minor concentrations, their quantification in dusts and sediments requires from any method of analysis the capacity to analyse to low concentrations (i.e. below the detection levels of $\mathrm{x}$ ray diffraction, for example). Diffuse reflectance spectrometry and environmental magnetic methods offer potential in this regard, these measurements responding selectively to the iron oxide- 
specific signals of colour and magnetic properties, respectively (Arimoto et al., 2002; Balsam et al., 2007; Maher et al., 2007; Watkins et al., 2007).

Figure 7.

\section{The palaeo-dust record for the last glacial maximum.}

4.1 Dust fluxes, size distributions, mineralogy.

Glacial/interglacial changes in the flux and particle size of dust have been recorded in ice cores and sediment records, both continental (windblown loess, lake sediment and peat records) and marine. Spanning the entire transect from pole to equator to pole, these dust records have shown that dust flux was higher in both hemispheres during past glacial stages (fig. 8). In light of the ongoing debates regarding modern dust supply and transport outlined above, what does the palaeo-dust record represent? Flux changes may record information on changes in the dust supply, reflecting changes at and/or of source area(s). Source areas may have expanded, through glacigenic action (Mahowald and Muhs, 2006), emergence of continental shelves into the subaerial zone (Bigler et al., 2006), and (seasonally-extended) expansion of arid and semi-arid areas (Werner et al., 2002; Tegen et al., 2002). Particle size changes may reflect changes in transport and/or source. Many palaeoclimate studies have used dust size as an indicator of wind strength in source regions (i.e. larger particles indicate stronger palaeo-winds, e.g. Rea 1995) or changes in the transport pathway (smaller particles indicate longer transport pathways, e.g. Lambert et al., 2008). Clearly, these arguments only hold if there is no change in the source size distributions, and no change in the source-sink distance. However, transporting winds may have altered in their trajectory and/or speed or gustiness (see section 3.2.1). Transport paths may have been effectively extended or shortened by changes in the degree of rain-out en route (Yung et al., 1996; Ruth et al., 2005; Lambert et al., 2008). Deposition rates on land may have varied in response to changes in vegetation and resultant trapping of dust by increased surface roughness (Marticorena and Bergametti, 1995; Marticorena et al., 1997).

Rates of dust deposition in sediment records are most often reported (e.g. Kohfeld and Harrison, 2001) as aeolian mass accumulation rates (MARs), calculated as: 
$\operatorname{MAR}\left(\mathrm{g} \mathrm{m}^{-2} \mathrm{a}^{-1}\right)=\operatorname{LSR} \times \operatorname{DBD} \times f$

where LSR = the linear sedimentation rate (calculated as the thickness of the sediment section (m)/ the time taken for the sediment to accumulate (yrs), DBD is the dry bulk density of the sediment $\left(\mathrm{g} \mathrm{m}^{-3}\right)$, and $f$ is the fraction of the sediment that is of aeolian origin. Figures 9a and 10a show aeolian MARs for the present day and the LGM, respectively, as collated in our updated version ('DIRTMAP3') of the original 'Dust indicators and records of terrestrial and marine palaeo-environments, DIRTMAP' database (Kohfeld and Harrison, 2001). For comparison, figures $9 \mathrm{~b}$ and $10 \mathrm{~b}$ show modelled present day and LGM dust fluxes (Mahowald et al., 2006). Here, we discuss LGM deposition rates (as archived in DIRTMAP3); comparisons between these palaeo-data and the model simulations are discussed in section 6.2.

Figure 9.

Figure 10.

\subsection{The continental loess record.}

For the terrestrial environment, sequences of loess sediments provide key aeolian archives on every continent. High-resolution loess/palaeosol sequences can provide new understanding of the relation between aerosols and climate (e.g. Maher, 2007): they provide a record of dust accumulation over large continental areas (Kukla, 1987; Thompson and Maher, 1995); they can be dated directly (Roberts, 2008; Roberts and Duller, 2003), to obtain dust flux changes through time; and they provide mineralogical, physical and chemical information on transported dust (e.g. Prins et al., 2008; Sun et al., 2008), which in turn may affect biogeochemical cycles in the ocean. Loess sequences can act both as a sink and a source for aeolian sediments. For example, the Chinese Loess Plateau, the largest Quaternary accumulation of windblown sediment in the world, has been identified by elemental and isotopic characterization as a major dust source for the sedimentary record of the northwest and equatorial Pacific (Rea et al., 1994; Shigemetsu et 
al., 2007; Ziegler et al., 2008). In turn, the glacial stage units of the Chinese Loess Plateau comprise extremely well-mixed dust sourced most likely by westerly transport from the western Taklimakan Desert and the northern margins of Tibet (e.g. Maher et al., 2009). The controversy over the extent of Tibetan glaciations during past glacial stages, and hence the extent of glaciogenic supply of loess, remains unresolved at present (e.g. Lehmkuhl and Owen, 2005).

Reflecting the proximal nature of many loess deposits to their sources, loess MARs at the LGM are the highest of any recorded aeolian fluxes (fig. 10a). For North America, for example, last glacial MARs in excess of $6,700 \mathrm{~g} \mathrm{~m}^{-2} \mathrm{a}^{-1}$ have been recorded from loess sections in central Nebraska (Roberts et al., 2003). Provenance information indicates that these extremely high deposition rates reflect increased sediment supply resulting from desiccation and expansion of areas of the Great Plains, rather than from glacial production of silt-sized particles (Aleinikoff et al., 2008). In light of MARS typically ranging from $\sim 100 \mathrm{~s}$ to $1000 \mathrm{~s} \mathrm{~m}^{-2} \mathrm{a}^{-1}$, and notwithstanding their proximal and thus coarser-grained nature, loess transport on such a scale inevitably incurred deflation and entrainment of large volumes of finer particles $(<10 \mu \mathrm{m})$, of potentially significant radiative impact. For the central Nebraskan region, for example, $\mathrm{PM}_{10}$ MARs range from $\sim 500$ to $>900 \mathrm{~g} \mathrm{~m}^{-2} \mathrm{a}^{-1}$; such high rates of fine particle flux suggested to have caused prolonged post-LGM cooling in the central N. American region (Roberts et al., 2003). Elsewhere in N. America, loess was supplied from glacial sediment sources, downwind from the Rocky Mountains, and close to rivers issuing from the southern margins of the Late Wisconsin ice sheet. Significant loess accumulations span areas of Iowa, Illinois and Kansas; further north and west, parts of Idaho, Wyoming, Alaska and the Yukon peninsula (fig. 10a).

For the Eurasian region of the northern hemisphere, a swathe of loess girdles Eurasia from west to east (fig. 10a), reflecting dust supply both from expanded glacigenic and arid/semi-arid sources. For the European zone, loess MARs typically range from $\sim 200$ to $600 \mathrm{~g} \mathrm{~m}^{-2} \mathrm{a}^{-1}$ for the last glacial stage, with some 'hotspots' of deposition reported, e.g. for the Nussloch site, Germany ( $>2000 \mathrm{~g} \mathrm{~m}^{-2} \mathrm{a}^{-1}$, Rousseau et al., 2002) and Paks in Hungary ( $>1000 \mathrm{~g} \mathrm{~m}^{-2} \mathrm{a}^{-1}$, Frechen et al., 1997). Extending eastwards over the Russian steppe, loess MARs have a similar range $\left(\sim 200-700 \mathrm{~g} \mathrm{~m}^{-2} \mathrm{a}^{-1}\right)$, rates then increase towards Tajikistan $\left(\sim 1700 \mathrm{~g} \mathrm{~m}^{-2} \mathrm{a}^{-1}\right.$, Frechen and Dodonov, 1998) and into the loess sequences of China. Across the Chinese Loess Plateau, 
the increase in MARs during the last glacial stage, as estimated from median MARs across the region, is of the order of up to $\mathrm{x}$ 5, i.e. $\sim 300 \mathrm{~g} \mathrm{~m}^{-2} \mathrm{a}^{-1}$ compared to an estimated $65 \mathrm{~g} \mathrm{~m}^{-2} \mathrm{a}^{-1}$ for the last interglacial stage ( $125 \mathrm{ka}$, MIS5e) (Kohfeld and Harrison, 2003). However, the range of LGM MARs estimated for the Loess Plateau spans $<100$ to $>1000 \mathrm{~g} \mathrm{~m}^{-2} \mathrm{a}^{-1}$. In common with most of the world's loess sequences, major spatial and temporal (sub-millennial) variability of these glacial-stage increases in dust flux have been reported (e.g. Zhang et al., 2002). In terms of mineralogy, quartz ( $35 \%)$, feldspars $(\sim 20 \%)$, clay minerals ( $25 \%$, illite and illite-smectite) and calcite (12\%) make up the very well-mixed loess (Jeong et al., 2008). Magnetic analyses additionally quantify the presence of minor amounts of haematite and goethite $(\sim 1 \%)$; the grain size of the haematite in the interbedded palaeosols is distinctively sub-micrometre, and confers the reddish hues to these soils (Maher, 2007).

Figure 11

A characteristic feature of many loesses is their trimodal particle size distribution, with overlapping coarse and fine size modes (fig. 11, and e.g. Wang et al., 2006; Machalett et al., 2008; Lim and Matsumoto, 2008). For the Chinese Loess Plateau, particle size end members have been identified (Prins et al., 2007) comprising a 'sandy loess' component (modal size 63 $\mu \mathrm{m}$ ), a 'silty loess' (modal size $37 \mu \mathrm{m}$ ), and a 'clayey loess' (modal size $22 \mu \mathrm{m}$ ). The two coarser end members are thought to reflect saltation and suspension of 'local' coarse dust during dust storms in spring; the finer end member inferred to represent higher level transport by background and dust storm supply. For these sequences, increases in the proportion of coarse particles has been interpreted as an increase in wind speed and thus of more intense winter monsoon circulation (e.g. Xiao et al., 1995; Maher and Hu, 2006). The increased glacial-stage MARs are also associated with increased particle size. At Luochuan, central Loess Plateau, for example, the median diameter of aeolian quartz particles is $\sim 15 \mu \mathrm{m}$ for the last glacial stage sediments compared with $\sim 6-9 \mu \mathrm{m}$ for the Holocene (fig. 12; Xiao et al., 1992). These paired increases in fluxes and particle size may indicate both expanded source areas and increased wind speeds, possibly coupled with a shortened transport path. Asian dust is and has been a major component of the sedimentary record of the Pacific Ocean (see section 4.3). Downwind of the Loess Plateau, present day estimates of dust flux range from $\sim 6$ to $12 \times 10^{6}$ tons of Asian dust 
transported annually to the central North Pacific. Larger quantities are probably deposited over the western North Pacific, closer to the Asian sources (Uematsu et al., 1983).

\section{Figure 12}

For the southern hemisphere, significant loess accumulations exist in South America and New Zealand (fig. 10a). For the South American continent, the loess sequences of the Argentinian pampas (the central Argentinian plains) cover $\sim 1.0 \times 10^{6} \mathrm{~km}^{2}$, with an average thickness of $\sim 30$ $40 \mathrm{~m}$, thus comprising the largest loess accumulation in the southern hemisphere. Many of these sequences have yet to be analysed in detail; age control is limited for the Tezanos Pinto Formation, traditionally considered to represent the last glacial stage but possibly extending to $145 \mathrm{ka}$ (Kemp et al., 2004). Estimated/adjusted MARs for the Pampas for the LGM are thus scarce but range from 45-145 $\mathrm{g} \mathrm{m}^{-2} \mathrm{a}^{-1}$ (Krohling and Iriondo, 1999, cited in Mahowald et al., 2006). Primary sources of these aeolian sediments are linked directly or indirectly to the Andean region and the arid diagonal located to the west. In general, the composition of the Argentine loess mirrors the mineralogical and chemical composition of Andean rocks (Gaiero, 2007). Reflecting a dominant Patagonian dust source, the southern loess deposits ( $\left.236-38^{\circ} \mathrm{S}\right)$ have similar chemical and isotopic composition and a dominance of smectite, with illite present in smaller amounts (Gaiero et al., 2004). This contrasts with the clay mineralogy of northern loess deposits ( $\left.26-28^{\circ} \mathrm{S}\right)$, dominated (Schellenberger and Veit, 2006) by illite (70-85\%), followed by smectite (10-25\%). Between the northern and southern loesses, illite slightly dominates the mineralogical composition of loess, while the coastal plains (Buenos Aires province) exhibit an approximately equal mixture of smectite, illite and kaolinite (Zarate, 2003). The loess deposits are coarse-textured. In the southern Pampas, the average sand-silt-clay content is $44 \%, 26 \%$ and $24 \%$, respectively, the maximum sand content (mostly very fine sand) being $\sim 80 \%$ (Bidart, 1996). Magnetic properties of loess from this area indicate the presence of detrital magnetite and titanomagnetite as the main ferromagnesian minerals (Orgeira et al., 2009). Northern loess deposits show fairly uniform particle size (silt loam) averaging $14 \%$ sand, $74 \%$ silt, and 12 $\%$ clay. $80 \%$ of the iron in the sediment is in paramagnetic minerals; $\sim 20 \%$ of the iron is in hematite $(\sim 1.6 \%$ of the sediment's mass), and $<<1 \%$ of the total iron is present as magnetite/maghemite ( $\sim 0.1 \%$ of the sediment's total mass) (Carter-Stiglitz et al., 2006). 
Elsewhere in the southern hemisphere, loess occurs most extensively in New Zealand, notably in the lowlands surrounding formerly glaciated areas of the South Island (Eden and Hammond, 2003). Glacial and floodplain sources have dominated dust production in New Zealand; its loess deposits are thicker (or possibly better documented) than in the S. American Pampean region, for example. Locally, Holocene loess has accumulated up to several metres thickness and very thick ( $>10 \mathrm{~s} \mathrm{~m}$ ) LGM accumulations have been documented (Berger et al. 2002). MARs for the LGM range between 70 to $150 \mathrm{~g} \mathrm{~m}^{-2} \mathrm{a}^{-1}$ (Eden and Hammond, 2003). Most of the New Zealand loess is quartz- and feldspar-rich. Glacially-derived loess deposits are strongly weathered (Marx et al., 2005), being clay-poor but mica-rich and relatively coarse-grained compared to dust derived from arid lands (McGowan et al., 2005). Loessic sediments occur to more limited extents in other southern hemisphere countries. The 'parna' of southeastern Australia, for example, is characterised by low supply and deposition rates; it dominantly comprises illite and kaolinite, carbonate and silt-sized quartz particles (e.g. Summerell et al., 2000). Accumulation rates measured at a $3 \mathrm{~m}$ loess section in the highlands west of Sydney were relatively unchanged from 50-10 ka, at between $28-45 \mathrm{~g} \mathrm{~m}^{-2} \mathrm{a}^{-1}$ (Hesse et al., 2003).

\subsection{The palaeo-dust record of HNLC regions in the Pacific.}

As discussed above, the dust-generating regions of E. Asia appear to have expanded and contracted across a range of glacial/periglacial and arid zone environments during the LGM. In turn, these source changes have produced major changes in dust flux and dust characteristics to the downwind continental sequences of the Chinese loess and palaeosols, and thence onwards to the northwestern and equatorial Pacific.

For the northwest and the equatorial Pacific regions, there are globally important questions regarding the possible causal role of changes in ocean biogeochemistry and export production (carbon sequestration, i.e. biomass permanently removed from the carbon cycle) during the glacial and interglacial stages of the Quaternary. The importance of understanding the influence of aeolian-supplied Fe can be illustrated by recent fertilization experiments in the northwest region of the Pacific, where iron-enrichment experiments led to the greatest expansion yet observed of phytoplankton standing stocks, together with shifts to dominance of large centric 
diatoms (Tsuda et al., 2003; de Baar et al., 2005). These two features suggest that the NW Pacific Ocean may be particularly sensitive to iron fertilization. With regard to export production (i.e. subsurface storage, rather than re-release from the ocean mixed layer), the drawdown of atmospheric carbon resulting from this experiment is estimated at $\sim 150-1500 \mathrm{C}$ atoms per iron atom added (see section 3.1; de Baar et al., 2008). The controversial question of whether changes in palaeo-dust fluxes have caused past changes in ocean productivity in the NW Pacific is also outlined here. Unequivocal identification of palaeo-productivity changes in the Pacific remains challenging in light of: differing approaches to determining sediment fluxes; varying rates of formation and dissolution of individual biogenic components (e.g. carbonate and opal; Honjo et al., 1995); and varying interpretations of radionuclide (e.g. ${ }^{230} \mathrm{Th}$ ) and organic degradation products (e.g. biogenic barite). Combined, these issues have resulted in difficulties in quantifying and integrating different biological products and hence total marine export production. As discussed below, different proxies and different approaches to age models have resulted in differing interpretations of glacial-interglacial changes in palaeo-productivity.

\subsubsection{Northwest Pacific dust fluxes}

Reported as one of the best records of aeolian flux from the NW Pacific, core V21-146 from the Shatsky Rise $\left(37.7^{\circ} \mathrm{N} 163^{\circ} \mathrm{E}\right)$ was retrieved from an elevated core site which lies beneath the loess-transporting westerlies and provides a robust $\delta^{18} \mathrm{O}$ record for age control (Hovan et al., $1989,1991)$. These Shatsky Rise sediments display increased dust fluxes $(\sim$ x 3.5, i.e. from $\sim 2$ to $7 \mathrm{~g} \mathrm{~m}^{-2} \mathrm{a}^{-1}$ ) during glacial stages, and indicate a direct link between intervals of accelerated continental deposition of loess and enhanced dust flux to the open ocean. Variations in aeolian grain size in the Shatsky Rise (fig. 13) show forcing at Milankovitch orbital frequencies, but coarser grains (median diameter $\sim 8 \mu \mathrm{m}$ ) show some association both with interglacial stages (at the $100 \mathrm{ka}$ frequency) and with low tilt and maximal precession, i.e. associated with glaciations (Rea, 1994). Gravity core $\mathrm{H} 3571$ was recovered from the Hess Rise $\left(34.9^{\circ} \mathrm{N} 179.7^{\circ} \mathrm{E}\right)$ some $1500 \mathrm{~km}$ to the east of the Shatsky Rise site and $\sim 3000 \mathrm{~km}$ from the Chinese mainland. This record also displays higher dust fluxes during glacial stages, of similar magnitude to the V21-146 record. However, these two records show significant differences in the timing and magnitude of their dust flux maxima; V21-146 has maximal fluxes at the LGM, for example, while H3571 displays only moderate flux values $\left(\sim 5.5 \mathrm{~g} \mathrm{~m}^{-2} \mathrm{a}^{-1}\right)$ at this time. 
Tracing Asian dust around its entire northern hemisphere trajectory, the Chinese loess, Pacific deep-sea record and Greenland ice cores all display large and rapid changes both in dust flux and particle size from interglacial into glacial climate stages (fig. 12). It is notable too that large dust flux changes are also evident within glacial stages, on sub-millennial timescales. The relative significance of changes in source (e.g. stronger and/or more frequent dust emission events) compared with changes in transport efficiency (e.g. shorter transit times and/or reduced rain-out en route) has been the subject of debate (e.g. Nilson and Lehmkuhl, 2001; Ruth, 2005; Lambert et al., 2008; Fischer et al., 2007). For the North-Greenland Ice Core Project (NGRIP) core, at the distal end of this transport path, the dust source is thought from isotopic evidence to have remained 'constant' through glacial and interglacial stages, i.e. the Taklimakan and Tengger/Mu Us deserts of W. China and Inner Mongolia, respectively (Svensson et al., 2000; Bory et al., 2003), though this is poorly expressed by models (e.g. Andersen et al., 1998). Given stationary sources, the evidence for increased dust flux all along the transport pathway, i.e. from the proximal Chinese loess sequences (e.g. Xiao et al., 1999; Ding et al., 2002), and across the midlatitude Pacific (e.g. Hovan et al., 1991; Kawahata et al., 2000) does indicate stronger and/or more frequent winds at source (Ruth, 2005). This conclusion requires careful examination, however. Care is needed in linking the more proximal loess sequences with the distal Pacific record. First, from air mass back-trajectory analysis, present day (coarse, $\sim 2-20 \mu \mathrm{m}$ ) dust supply to the Loess Plateau appears dominantly controlled by ambient (non-dust storm) northwesterly surface winter winds (Zhang et al., 1999). This is in contrast to the (fine-grained) LRT dust, which is uplifted during springtime dust storms from sources such as the western Taklimakan Desert (Bory et al., 2003) and carried by the westerly jet at upper levels $(\sim 5-8 \mathrm{~km})$ before descending towards the northeasterly trade winds, to the south and east of the subtropical high (Zhang et al., 1999). In contrast, during glacial stages, the dust source for both the LRT dust and the Loess Plateau appears, on multi-proxy elemental and magnetic grounds, to have been the same, dominantly the western desert and Tibetan Plateau regions (Maher et al., 2009; Torii et al., 2001). Second, in terms of particle size, glacial-interglacial variations of particle size along the proposed dust trajectory - from the East Asian deserts to the Loess Plateau to the NW Pacific to Greenland - present some complications. For the Loess Plateau and for NGRIP, glacial stages are associated with increased particle size (fig. 12). Glacial stages in the NGRIP dust record are characterized by particles $>1.6 \mu \mathrm{m}$ in diameter; interglacials by particle sizes $\sim 1 \mu \mathrm{m}$. 
For the NW Pacific (Shatsky Rise), in contrast, finer sizes (median diameter $\sim 3 \mu \mathrm{m}$ ) have been reported for glacial stages and coarser sizes $(5 \mu \mathrm{m})$ during interglacials (e.g. Hovan et al., 1991), whilst data collated by Zhang et al. (2007) show no clear glacial-interglacial trend (fig. 13).

Figure 13

\subsubsection{Equatorial Pacific dust fluxes}

Until recently, consistency of glacial-interglacial records of dust flux has been difficult to obtain for the equatorial Pacific, reflecting the confounding effects of sediment redistribution by bottom water currents (e.g. Mitchell and Lyle, 2005) and inputs of volcanically-derived aerosols (Olivarez and Owen, 1991). Critically, glacial to interglacial aeolian fluxes estimated from oxygen isotope-derived age models have varied both in sign and magnitude (e.g. Rea, 1994; Murray et al., 1995). Development of the ${ }^{230}$ Th normalization method (Bacon, 1984; Francois et al., 1991; Francois et al., 2004) may provide a means (Lyle et al., 2007; Broecker, 2008) to calculate truly aeolian MARs. This method is based on the assumption that the rain-out rate of particulate ${ }^{230} \mathrm{Th}$ sinking to the sea bed is equivalent to the known rate of ${ }^{230} \mathrm{Th}$ production by ${ }^{234} \mathrm{U}$ decay in the overlying water column. MARs are calculated by dividing the production rate of ${ }^{230} \mathrm{Th}$ in the water column by the concentrations of scavenged ${ }^{230} \mathrm{Th}$ in the sediment. In tandem, terrigenous dust fluxes have been estimated for these sediments by using the ratio of ${ }^{232} \mathrm{Th}$ ) and ${ }^{230} \mathrm{Th}$ as a proxy for dust flux. ${ }^{232} \mathrm{Th}$ is dominantly sourced from continental dust sources (its concentration in volcanogenic materials, for example, is an order of magnitude lower), it is almost insoluble in seawater, and is not subjected to any post-depositional redoxrelated change. Differences in dust provenance have so far been reported to exert relatively little effect on measured ${ }^{232} \mathrm{Th}$ concentrations, falling within $1 \mathrm{ppm}$ of the upper continental crustal average of 10.7 ppm (Anderson et al., 2006). For an increasing number of sediment cores spanning the equatorial Pacific, recent studies making use of these techniques consistently demonstrate increased dust fluxes during glacial stages, with dust fluxes up to $2.5 \mathrm{x}$ higher during the last glacial stage (Anderson et al., 2006; McGee et al., 2007, Winckler et al., 2008). Dust fluxes decrease from west to east, and towards the south, where northern and equatorial South American dust sources may contribute (Anderson et al., 2006), compared to the dominantly Asian-sourced aerosol towards the north (Ziegler et al., 2009). These new data 
indicate a coherent response by dust generation and transport processes, from the equator to the South Pole, to glacial/interglacial climate changes through the late Pleistocene (fig. 14). The gradient in dust flux values from north to south across the equator may change through time in response to changes in the latititudinal position and/or the intensity of the intertropical convergence zone (Rea, 1994; Rea and Hovan, 1995; McGee et al., 2007; Ziegler et al., 2008). As noted by Anderson et al. (2006) and Winckler et al. (2008), the observed equatorial Pacific glacial flux increase (up to $\mathrm{x} 2.5$ higher) is very different from modelled dust fluxes for this region. For example, while earlier models (Mahowald et al., 1999, Reader et al. 1999) produced unrealistically large LGM flux increases (LGM/modern ratios ranging between 12 and 105), more recent simulations result in disproportionately low LGM fluxes and also a west to east increase in flux (Mahowald et al., 2006).

Figure 14

\subsection{The palaeo-dust record of the HNLC ocean regions: Antarctic ice cores and Southern} Ocean.

\subsubsection{Antarctic ice cores}

Some of the longest, most detailed palaeo-dust records have been retrieved from the Antarctic polar region. Our interpretation of this paleo-record would be greatly facilitated by measurements of present-day dust transport. Unfortunately, there are remarkably few dust data in the Southern Hemisphere and, consequently, a major problem in quantifying LGM/modern dust flux ratios for the wider Southern Ocean region is the paucity of data with which to assess present day dust fluxes from any of the S. hemisphere land masses (section 2.2). Dust fluxes recorded in Antarctic ice cores show that across the southern polar region dust flux was $\sim 30 \mathrm{x}$ higher during the LGM (fig. 15). The reasons for this very large increase in dust at the LGM can be multiple. Source regions over Patagonia were certainly extended due to drier conditions and the decrease in sea-level that left exposed wide continental regions. In addition, the transport paths could have been changed and the wet deposition is likely to have been considerably reduced. These factors taken in combination or seldom can explain the differences seen in the deposition fluxes in the ice cores (Yung et al., 1996). 
The growing number of ice cores retrieved from the Antarctic plateau provide long, undisturbed dust and climate records (extending back over eight glacial cycles) representing not only the Southern Ocean region but also sectoral differences (fig. 16) within that region (Fischer et al., 2007). High resolution dust flux records can be compared between several locations, including Vostok (78 $\left.28^{\prime} \mathrm{S} 106^{\circ} 48^{\prime} \mathrm{E}\right)$ (Petit et al., 1999) and the two EPICA sites (EPICA community members, 2006), Dome C (EDC, $75^{\circ} 06^{\prime} \mathrm{S}, 123^{\circ} 21 \mathrm{E}$, in the Indian Ocean sector) and at Kohnen station in Dronning Maud Land (EDML: $\left.75^{\circ} 00^{\prime} \mathrm{S}, 00^{\circ} 04^{\prime} \mathrm{E}\right)$, and Talos Dome $\left(72^{\circ} 48^{\prime} \mathrm{S} 159^{\circ}\right.$ 06'E; Delmonte et al., 2009). For all these cores, the dust profiles are extremely similar both in terms of total dust flux and the magnitude of the glacial/interglacial changes (Fischer et al., 2007; Lambert et al., 2008) with high dust fluxes during glacial stages; up to $30 \mathrm{x}$ higher compared with the Holocene and earlier interglaciations. At EDC, total dust fluxes range from $\sim 0.4 \mathrm{mg} \mathrm{m}^{-2}$ $\mathrm{a}^{-1}$ at the Holocene to $12 \mathrm{mg} \mathrm{m}^{-2} \mathrm{a}^{-1}$ during glacial maxima. Tight coupling of the dust and climate records is especially evident during cold intervals of glacial stages (i.e. when $\delta \mathrm{D}>\sim 425$ \%o, Lambert et al., 2008). Episodes of warming are linked with reduced dust fluxes; for instance, each of the Antarctic isotopic maxima (EPICA community members, 2006) is associated with a decline in dust fluxes at both the EDC and EDML sites (Fischer et al., 2007), indicating synchronous changes in the dust source regions (e.g. reduced dust supply and/or reduced wind speeds).

1034

Figure 16.

Comparison of the EDML and EDC records identifies that the flux of non-sea salt calcium (i.e. as a mineral dust proxy) was $3 \mathrm{x}$ higher at the EDML, Atlantic sector site; this higher flux is attributed to its greater proximity to S. American dust sources (Fischer et al., 2007). Debate is ongoing with regard to the relative influences of glacial-interglacial changes in source strength and changes in dust transport processes (especially atmospheric residence time and transport rate) on rates of dust deposition at Antarctica (e.g. see Fischer et al., 2007 compared with 
the Atlantic sector of the Southern Ocean, lying between the S. American sources and the Antarctic region, should approach those observed in Antarctica (see section 4.4.2).

An additional if subtle complication arises with reported regional differences dust particle size around the different Antarctic sectors (Delmonte et al., 2004). In terms of dust particle size, the mass-size distribution of aeolian particles in east Antarctica is well sorted around a mean mass diameter of $2 \mu \mathrm{m}$, the largest particle diameter is $\sim 5 \mu \mathrm{m}$, and the contribution of particles $<0.7$ $\mu \mathrm{m}$ contributes $<\sim 10 \%$ of the total mass (Delmonte et al, 2004b). However, during glacial stages, smaller particles were deposited at the EDC site, in contrast to Vostok and Dome B, where increased particle size has been reported during glacial stages (Petit et al, 1982; Delmonte et al. 2004).

Provenancing of the Antarctic dust by magnetic (Maher, 2009), elemental (Marino et al., 2008) and isotopic, $\mathrm{Sr}$ and $\mathrm{Nd}$, techniques (e.g. Grousset et al., 1992; Basile et al., 1997) is still being refined, in order to extend the range of well-characterised potential source areas. As noted by Mahowald et al. (1999), no potential source area can be discounted or verified if it has not been sampled and characterised. It is also essential to take into account particle size effects on mineral, elemental and isotopic signatures (figure 17a and b and e.g. Delmonte et al., 2004; 2009). For dust both at Vostok and EDC, the isotopic fields are almost identical (within the ranges $0.708<{ }^{87} \mathrm{Sr}:{ }^{86} \mathrm{Sr}<0.711$ and $\left.-5<\varepsilon \mathrm{Nd}(0)<+5\right)$, indicating a common dust source across the East Antarctic region. So far, around 60 potential source areas samples from S. America (33 samples), New Zealand (15), Australia (22), southern Africa (6) and the Antarctic Dry Valleys (6) have been subjected to isotopic analysis of their fine size fractions $(<5 \mu \mathrm{m})$, encompassing loess and loess-like deposits, silts and sands, fluvioglacial sediments, soils, moraines (Delmonte et al., 2004, 2007, 2009) and glacial lacustrine deposits (Sugden et al., 2009). At present, those potential source areas showing partial overlap with the glacial stage ice core dusts are S. America, New Zealand, the Antarctic Dry Valleys (fig. 17), and some Australian areas (Lake Eyre). The overlap with Australian-sourced samples increases for interglacial stage samples (Revel-Rolland et al., 2006; Delmonte et al., 2007; 2009; Marino et al., 2008).

Figure 17. 
1076 So far, the consensus has been that Patagonia, and possibly the Puna Altiplano area, have been the major glacial dust sources for the Antarctic ice records (Gaiero, 2007; Delmonte et al., 2007). Satellite observations identify these hypothesized source regions as prominent present-day dust sources (see fig. 3b, section 2.2). Lowered glacial-stage sea level rendered Patagonia twice as large as today and glacial activity was extensive; this region was most likely an intense dust source during the LGM and previous glacial stages (e.g. Iriondo, 2000; Sugden et al., 2009). There is no published continental record of Quaternary dust accumulation from Patagonia, reflecting the high potential for wind erosion and poor geomorphic conditions for sediment accumulation. Rather, loess accumulation was concentrated further to the north and east in the pampas of Argentina (e.g. around $\sim 30^{\circ} \mathrm{S}, \sim 60^{\circ} \mathrm{W}$ ). Age control for these loess sequences has not been well established yet, but MARs at the LGM are estimated at between $\sim 45$ and $145 \mathrm{~g}$ $\mathrm{m}^{-2} \mathrm{a}^{-1}$ (Krohling and Iriondo, 1999). Evidence for direct links between the Antarctic records of dust deposition and activating sources within the Patagonian region comes from chronological and isotopic data on glacial outwash sediments fringing the Straits of Magellan (Sugden et al., 2009). During the last glaciation, an Andean ice sheet developed between latitudes $44^{\circ} \mathrm{S}$ and 55 ${ }^{\circ} \mathrm{S}$. Outlet glaciers flowing eastwards from this ice sheet debouched into large outwash plains, with meltwater eventually draining into the S. Atlantic Ocean. When the outlet glaciers advanced to terminate directly at the outwash plains around the (then emergent) Magellan Straits, large amounts of glacigenic dust were supplied and available for uplift and transport by intensified westerly winds. Conversely, when the glaciers terminated in proglacial lakes, the dust supply was effectively 'switched off'. Isotopic analysis ( $\mathrm{Sr}, \mathrm{Nd})$ of the finest fraction $(<5 \mu \mathrm{m})$ of Magellan glacial lacustrine sediments indicates that they may have been one of the sources of the Antarctic dust during glacial stages (Sugden et al., 2009). Correlation between the dated sequence of Patagonian glacial activity and the Antarctic (Dome C) dust peaks is good, although anomalies do occur (e.g. the ice core dust peak at 30 ka has no glacial correlative in Patagonia; and the dated sediments are lacustrine, possibly indicative of periods of glacial retreat rather than advance). Rapid retreat of the glaciers can account for the observed rapid decreases in dust flux during deglaciation. Notably, the deglacial decline in Antarctic dust flux precedes the reduction in sea ice in the Southern Ocean, the warming of the Southern Ocean and the deglacial rise in sea level (Sugden et al., 2009; Fischer et al., 2007; Wolff et al., 2006). One problem with this 
proposed glacial outwash dust source is the key and characteristic presence of leaf wax-derived n-alkanes in the intervening sedimentary record of the Southern Ocean (see section 4.4.2); the presence of vegetation might suggest a more low-lying source area (e.g. the emergent coastal shelf) rather than a glacial/periglacial source.

\subsubsection{The Southern Ocean dust record}

It has so far proved difficult to quantify the flux of dust across the Southern Ocean, and thence to Antarctica, during past glacial stages. Glacial stage sediments are characterised by increased lithogenic MARs in all three sectors of the Southern Ocean but these sedimentary records have diverse terrigenous contributions, including iceberg-rafted debris, current-transported sediment and aeolian dust (Diekmann, 2007). As with the Pacific sedimentary record, significant lateral transport of sediment by strong bottom water currents has affected the Southern Ocean records. There are presently very few integrative studies which have used a range of independent proxies to establish robust lithogenic and aeolian MARs, and identify glacial/interglacial changes in export production. Martínez-Garcia et al. (2009) present multiproxy-derived estimates of dust and iron supply, and marine productivity, over the last 1.1My from a deep-sea sediment record (PS2489-2, ODP Site 1090) located in the subantarctic South Atlantic (fig. 18). The initial age model for this composite sedimentary record was obtained by oxygen isotope analysis of benthic foraminifera (prior to tuning by correlation between the sediment sea surface temperature record and the EDC temperature record). Using ${ }^{232} \mathrm{Th}:{ }^{230} \mathrm{Th}$ as a proxy for dust flux (in combination with other terrigenous tracers, including long-chain n-alkanes derived from leaf waxes), these authors report dust fluxes varying from $\sim 1 \mathrm{~g} \mathrm{~m}^{-2} \mathrm{a}^{-1}\left(\sim 50 \mathrm{mg} \mathrm{m}^{-2} \mathrm{a}^{-1}\right.$ of iron) for interglacial periods, to $\sim 5-7 \mathrm{~g} \mathrm{~m}^{-2} \mathrm{a}^{-1}\left(\sim 250 \mathrm{mg} \mathrm{m}^{-2} \mathrm{a}^{-1}\right.$ of iron) for glacial stages (fig. 18). Assuming the dust source to be S. America, these estimates thus indicate up to $7 \mathrm{x}$ increase in the source strength for this region. This magnitude of change contrasts with the $\mathrm{x}$ 20-25 increase in dust flux recorded by the Antarctic ice cores (Lambert et al., 2008). These data suggest that increased dust source strength, due to increased (possibly glacially-driven) dust supply and/or higher wind speeds, might be less significant for the recorded Antarctic dust fluxes than increased efficiency of long range transport, due to shorter transit times and/or less rain-out en route.

Figure 18 
In terms of dust source, whilst very few dust flux data exist for either the present day or the LGM for this region, present day dust fluxes seem very low (see section2.2). Hence, it is probable that sources additional to present-day southern S. American source areas were active during the last glacial period. Recent research does indicate that southern S. America was the most important LGM dust source for this region, as evidenced by the dominant overlap of isotopic compositions of sediments from the Pampean loess (Gaiero, 2007), the Southern Ocean (Walter et al., 2000) and the Antarctic dust ( Delmonte et al., 2008). Modelling (Krinner and Genthon, 2003; Lunt \& Valdes, 2002) and mineralogical studies (Gaiero, 2007; Delmonte et al., 2008) indicate that $~ 80$ $\%$ of dust reaching the Antarctic Plateau during cold periods was derived from Patagonia. Less clear is the contribution of southern S. American materials to the South Atlantic Ocean. On isotopic grounds, glacial sediments from the north Scotia Sea seem dominated by a southernmost Patagonian source (Walter et al., 2000). However, compared with the potential southern S. American sources, sediments from the Atlantic sector of the Southern Ocean $\left(\sim 41^{\circ} \mathrm{S}, 14^{\circ} \mathrm{W}\right)$ display notably higher chlorite content (Diekmann, 2007). Total detrital MARs for this region are $\sim 15 \mathrm{~g} \mathrm{~m}^{-2} \mathrm{a}^{-1}$ for the last interglacial stage (MIS 5, $125 \mathrm{ka}$ ) and $\sim 120 \mathrm{~g} \mathrm{~m}^{-2} \mathrm{a}^{-1}$ for the LGM (Walter et al., 2000), but the aeolian contribution to these figures is not known.

For the other S. hemisphere land masses, the Murray-Darling basin was a major Australian dust source in the LGM, exporting dust towards the south and southeast (Hesse, 1994; Hesse and McTainsh, 2003). With dust storm frequency $50 \%$ higher (McTainsh and Lynch, 1996), the LGM flux of Australian dust to the mid-Tasman Sea $\left(160^{\circ} \mathrm{E}, 40^{\circ} \mathrm{S}\right)$ is estimated at $\sim 3 \mathrm{x}$ Holocene levels (Hesse, 1994). An additional LGM sediment source was the ancestral Lake Eyre basin (Dulhunty, 1982). Australian dust may have been a long-term contributor to the Southern Ocean and the southwest Pacific (Stancin et al., 2006, 2008) but the record is obscured by poor carbonate preservation in the deep Southern Ocean basins and reworking of sediments by strong Antarctic circum-polar circulation. In terms of particle size, LGM dust transported to the Tasman Sea from Australia (Hesse and McTainsh, 1999) comprises a minor coarse silt component (modal diameter 20-25 $\mu \mathrm{m}$ ) and dominant fine silt and clay $(<4 \mu \mathrm{m})$. Compared to the present day, there is little change either in the mode or the size of the coarser particles, indicating little change in the strength of the zonal westerlies over Australia at the LGM. The palaeo-dust 
contained within Tasman Sea sediments contains fine-grained haematite/goethite, the concentration of which varies directly with the dust concentration (Hesse, 1997). Thus, the flux of fine-grained haematite/goethite to the Southern Ocean and southwest Pacific and from Australia was greater in the LGM and previous glacials than in the Holocene and previous interglacials. (The volumetric flux of these minerals, however, has yet to be determined). Although New Zealand appears to be an insignificant source of dust to the Pacific sector of the Southern Ocean today (Prospero et al, 2002; fig. 3), it represents a (poorly documented) potential contributor of dust to the palaeo-Southern Ocean. Given its significant terrestrial accumulations of loess, New Zealand may have been a significant source of dust to the southwest Pacific and Southern Ocean at least during glacial intervals of the Late Quaternary. While the geochemical fingerprint of New Zealand dust overlaps glacial and interglacial Vostok dust signatures (figure 16; Delmonte et al., 2004, 2009), it is likely that New Zealand, like Australia, contributes more to the Pacific than other sectors of the Southern Ocean. It is notable that New Zealand's Taupo volcano has been excluded as a potential aerosol source for the Antarctic ice cores from Dome C $\left(75^{\circ} 06^{\prime} \mathrm{S} 123^{\circ} 21^{\prime} \mathrm{E}\right)$ and Vostok $\left(78^{\circ} 28^{\prime} \mathrm{S} 106^{\circ} 46^{\prime} \mathrm{E}\right)$, on the basis of its relatively high $\mathrm{SiO}_{2}$ content (Narcisi et al., 2005). The absence of Taupo-sourced tephra from the last $200 \mathrm{ka}$ of the Antarctic ice cores suggests that dust transport from the New Zealand/Australian region to Antarctica is inefficient (Delmonte et al., 2004; Narcisi et al., 2005). Yet Taupo volcanic dust has been found in Greenland ice cores (Zielinski et al., 1996); it seems unusual that there could have been no transmission of dust, at least to subantarctic Southern Ocean waters, given the extreme size of some eruptions. For example, in an eruption dated at $\sim 26.5 \mathrm{ka}$, Taupo emitted $\sim 1.4 \times 10^{18}$ $\mathrm{g}$ of tephra (Mason et al., 2004), i.e. $1000 \mathrm{x}$ the current global dust flux.

Given the current scarcity of present day or palaeo-dust flux and provenance data for the southern S. hemisphere region, model simulations remain to be validated. For the LGM, modelling of southern hemisphere dust deposition (e.g. Lunt and Valdes, 2002) suggests up to 15 $\mathrm{x}$ greater flux of South American dust in the Atlantic sector of the Southern Ocean (compared with up to $7 \mathrm{x}$ flux as reported by Martinez-Garcia et al., 2009), and $>90 \%$ contribution of S. American dust to deposition in the Atlantic and Indian Ocean sectors. In the Lunt \& Valdes (2002) study, the modelled LGM flux of Australian dust exceeds the S. American value (presumably reflecting the greater area of the Australian continent) but the Australian dust is 
dispersed over the entire Pacific sector of the Southern Ocean (Lunt and Valdes, 2002). Other modelled fluxes (Mahowald et al., 1999, 2006) indicate LGM/modern ratios in the Southern Ocean ranging from 0.5 to 2 (with dust sources as modelled for the present day) and 20 to 50 (with modelled expansion in dust sources at the LGM).

\section{Palaeo-productivity changes during the LGM in the HNLC regions}

\subsection{Northwestern and equatorial Pacific.}

In the context of iron fertilization, did the measured LGM enhancement of flux of Asian dust overcome iron limitation in the HNLC regions of the northwestern and equatorial Pacific, resulting in significant drawdown of atmospheric $\mathrm{CO}_{2}$ ? Export production has previously been reported to have been globally higher during the LGM, with just one exception, the Southern Ocean (Kohfeld et al., 2005). Some studies have identified an association between glacial climate stages and increased productivity in the Pacific Ocean. For example, for core H3571 from the NW Pacific, biogenic opal and organic carbon were both reported to have increased during glacial stages (Kawahata et al., 2000). Similarly, for sediments retrieved from the eastern equatorial Pacific, Pedersen (1983) identified peak sedimentary organic carbon content $\left(\mathrm{C}_{\mathrm{org}}\right)$ in association with the LGM. This study used the iodine: $\mathrm{C}_{\text {org }}$ ratio to rule out enhanced preservation as a causal factor and thus ascribed the peak $\mathrm{C}_{\text {org }}$ to a significant increase in productivity during the LGM. Using biogenic barite fluxes as a palaeo-productivity indicator and conventional stratigraphically-derived MARs, Paytan et al. (1996) also identified $\sim 2 \mathrm{x}$ higher export production during glacial stages for central and eastern equatorial Pacific cores.

More recent studies reporting increased glacial stage export production, in the western equatorial and subarctic Pacific, include those of Zhang et al. (2007) and Amo and Minagawa (2003), respectively. Zhang et al. (2007), using a mixture of micropalaeontological and foraminiferal isotopic $\left(\delta^{13} \mathrm{C}\right)$ proxies from Hole 807A (Ontong Java Plateau, $3^{\circ} 36.42 \mathrm{~N}, 165^{\circ} 37.49 \mathrm{E}$ ), find that productivity has been greater during glacial stages and has gradually increased since MIS13 ( $530 \mathrm{ka})$. They also find correlation between their palaeoproductivity record and the dust flux record in northwestern Pacific core V21-146 $\left(37^{\circ} \mathrm{N} 163^{\circ} \mathrm{E}\right)$, from the Shatsky Rise (Hovan et al., 1991). Zhang et al. (2007) thus suggest that dust transported from East Asia may be significant for enhancement of biological productivity in the western equatorial Pacific during glacial times. 
Similarly, Amo and Minagawa (2003) estimated temporal changes of organic carbon fluxes during the last $130 \mathrm{ka}$ from marine and terrigenous sources for sediments at the Shatsky Rise $\left(33.3^{\circ} \mathrm{N}, 159^{\circ} \mathrm{E}\right)$. In contrast with the minor input of terrestrially-derived carbon, $\mathrm{C}_{\text {marine }}$ was estimated at $>86 \%$ of the total organic carbon for the whole core, reaching highest accumulation rates $\left(9.2 \mathrm{mg} \mathrm{C} \mathrm{cm}^{-2} \mathrm{ka}^{-1}\right)$ in the LGM, and next highest rates in earlier glacial periods. From their alkenone-derived SST reconstructions, Amo and Minagawa (op. cit.) show that although cold sea surface temperatures (SSTs) prevailed at their Shatsky Rise site throughout MIS 2-4 ( 20 - 7- ka), export production peaked at the LGM, when aeolian dust flux to the site was also at a maximum. It should be noted that both this study and that of Zhang et al. (2007) use conventional $\delta^{18} \mathrm{O}$-derived chronologies for calculation of MARs.

However, recent work on equatorial Pacific sediments has contradicted these findings. Revising their previous conclusions, Paytan et al. (2004) reported that with normalisation of sediment accumulation rates using ${ }^{230} \mathrm{Th}$, the apparent glacial increases in Pacific productivity either disappeared or even reversed. They conclude that higher rates of biogenic flux during glacial stages result not from greater export production but from increased lateral influx of sediment, transported by bottom water currents. This problem of sediment focusing appears to be widespread across the equatorial Pacific region, as indicated by ratios in excess of 1 for ${ }^{230} \mathrm{Th}_{\text {measured: }}{ }^{230} \mathrm{Th}_{\text {expected }}$ water column production). In another approach, using calcite accumulation rates (excess ${ }^{230} \mathrm{Th}$-normalised and corrected for dissolution), Loubere et al. (2004) also estimated significantly reduced export production in the eastern equatorial Pacific (from 0.1 to $3.1^{\circ} \mathrm{S}$ and $84.65-95.65^{\circ} \mathrm{W}$ ) at the LGM, i.e. $~ 30-50 \%$ lower than during the Holocene. They attribute this reduction to lowered nutrient supply from the Southern Ocean via the equatorial undercurrent. This magnitude of productivity reduction is echoed by Bradtmiller et al.'s (2006) analysis of ${ }^{230} \mathrm{Th}$ normalized opal fluxes and ${ }^{231} \mathrm{~Pa}:{ }^{230} \mathrm{Th}$ ratios in eleven equatorial Pacific cores; Holocene opal burial rates those of the late glacial period by $35 \%$. Rather than systematic reduction in productivity during glacial stages, Anderson et al. (2008) report that ${ }^{230}$ Th-normalized barite fluxes (equatorial core, TT013-PC72, $140{ }^{\circ} \mathrm{W}$ ) exhibit no clear glacialinterglacial pattern of variability (fig. 19). Similarly, whilst acknowledging the absence of any 'ideal' palaeo-productivity proxy, Ziegler et al. (2008) identify no relationship between enhanced flux of Asian dust and ocean productivity, estimating similar export production rates at the LGM 
as at present day (for five equatorial cores retrieved at $140^{\circ} \mathrm{W}$ ). Nor do they find any relationship between palaeo-productivity and potential Fe supply by upwelling from the equatorial undercurrent.

For the subarctic, northwestern Pacific (ODP 882, $50.3^{\circ} \mathrm{N}, 167.5^{\circ} \mathrm{E}$ ), Jaccard et al. (2005) report reduced export production during glacial stages (defined using a $\delta^{18} \mathrm{O}$-derived age model), based on use of 'biogenic barium' as a palaeoproductivity proxy (i.e. sedimentary barite concentrations normalized by detritally-sourced aluminium). They attribute this glacial stage reduction in productivity to increased glacial ocean stratification, and reduced nutrient supply from upwelling. Their findings are supported by Shigemitsu et al. (2007) who report increased aeolian fluxes of loess during glacial stages but reduced marine productivity for another western subarctic Pacific core $\left(50^{\circ} \mathrm{N}, 164.9^{\circ} \mathrm{E}\right)$. Similarly, low glacial productivity (succeeded by increased deglacial productivity) is reported by Gebhardt et al. (2008), using biogenic opal and chlorins as proxy indicators for another piston core $\left(51.27^{\circ} \mathrm{N}, 167.7^{\circ} \mathrm{E}\right)$ near to ODP Site 882.

At present, therefore, where sedimentation rates have been normalized by excess ${ }^{230} \mathrm{Th}$, evidence suggests there has been no enhancement of ocean productivity and export production in the equatorial Pacific during the last glacial stage (fig.19). For the NW Pacific, varying with choice of proxy, contradictory evidence currently exists. As suggested by Gebhardt et al. (2008), productivity changes may have differed in time and space across the open ocean. However, selection and interpretation of productivity proxies in the Pacific region remain an ongoing issue and, as noted by Ziegler et al. (2008), it may be problematic to infer a change in total productivity from a change in any one particular biological component.

Figure 19.

\subsection{Southern Ocean.}

In terms of export production, Martínez-Garcia et al. (2009) report good correlation between glacial/interglacial changes in total organic carbon and the estimated fluxes of dust, indicating enhanced, and possibly dust-related, marine productivity in the subantarctic eastern Atlantic sector of the Southern Ocean during glacial stages (fig. 18). However, despite the high fluxes of 
dust recorded by the Antarctic ice cores during the LGM, glacial increases in TOC appear much greater during previous glacial stages. For example, while the LGM is characterised by $\sim 2 \mathrm{x}$ increase in TOC, increases of up to $\sim 28 \mathrm{x}$ are observed during MIS $10(\sim 360 \mathrm{ka})$ and earlier glacial stages. One feature common to all the glacial intervals recorded in this composite record is that increases in export production (i.e. above the average interglacial value) only occurred when the ice core record of $\mathrm{CO}_{2}$ concentration fell below $\sim 230$ ppmv (i.e. $>50$ ppmv lower than during interglacial stages).

\section{Figure 20}

Enhanced export production in the glacial subantarctic has previously been reported, based on a range of radionuclide proxies, for each sector of the Southern Ocean, but varying spatially across the sectors (Kumar et al., 1995; Pondaven et al., 2000; Dezileau et al., 2003; Chase et al., 2001, 2003). At the present day, biogenic opal accumulates at similar rates in each sector, in the permanently open-ocean zone of the southern part of the Antarctic Circumpolar Current (ACC), with productivity maxima south of the modern Polar Front (fig. 20). During the Last Glacial Maximum, opal accumulation rates decreased in the southern part of the ACC at similar rates in all three sectors, and increased at regionally different rates in the northern part of the ACC, with maxima in the Atlantic sector (Diekmann, 2007). This suggests that limitation on primary productivity was overcome to a greater extent in the Atlantic than in the Indian and Pacific sectors (fig. 19). For the LGM, thorium-normalised lithogenic MARs were $\sim 4 \mathrm{x}$ higher in the Atlantic than in the Pacific sector (Chase et al., 2003). Glacigenic and bottom water-transported sediments are likely, however, to have contributed most of the fine-grained terrigenous material to this sector (Diekmann, 2007; Maher and Dennis, 2001; Latimer and Filipelli, 2001; Tagliabue et al., 2009).

Figure 20

\section{Synthesis.}

6.1 LGM dust fluxes and changes in ocean productivity? 
It is clear from the palaeo-data that dust fluxes to the HNLC regions of the world ocean were higher during the LGM than at the present day. The key question arises of whether or not these increased mineral fluxes resulted in significant changes in marine productivity, export production (i.e. carbon sequestration, biomass that is permanently removed from the carbon cycle) and, consequently, drawdown of atmospheric $\mathrm{CO}_{2}$ during the last glacial stage.

As summarized above, a growing body of evidence suggests that there has been no enhancement of ocean productivity and export production in the equatorial Pacific during the LGM. For the NW Pacific, the evidence appears contradictory. The differences in data interpretation for this latter region may reflect heterogeneity in ocean productivity through time and space (Gebhardt et al., 2008), but choice and understanding of productivity proxy also remain an ongoing issue. Further, the relationships between productivity and export of carbon remain poorly resolved for this region. Data reported by Hays (2009), for example, indicate lower productivity at the LGM than in the Holocene but higher LGM export of carbon due to significant re-organization of the epipelagic food web, in particular the glacial dominance of more productive, deep-living ( $>200$ $\mathrm{m}$ water depth) radiolarian species (especially Cycladophora davisiana), as previously reported for the Sea of Okhotsk (e.g. Hays and Morley, 2004).

For the Southern Ocean, coupling between dust flux and export production is inferred by Martinez-Garcia et al. (2009), who note that the observed increase in export production during glacial stages is non-linear, rising only slowly in early glaciation stages before accelerating to peak at glacial maxima. They attribute this exponential pattern to dust-driven iron supply, with dust flux also rising exponentially as global ice volume increases (Ridgwell and Watson, 2002; Lambert et al., 2008). These data would indicate that dust-forced increases in Southern Ocean export production can induce significant $\mathrm{CO}_{2}$ drawdown but only during glacial maxima, and thus can account for $\sim 40-50$ ppmv drawdown of $\mathrm{CO}_{2}$ (i.e. as much as half of the total interglacial-glacial change of $\sim 100 \mathrm{ppmv}$ ). The apparent coherence between the productivity proxy (alkenones) and the record of change in atmospheric $\mathrm{CO}_{2}$ is notable (fig. 21c). Intervals where the relationship between dust flux, productivity and $\mathrm{CO}_{2}$ break down (e.g. $\sim 220 \mathrm{ka}$ ) seem quite rare but may provide some clue to the required additional causal factors in $\mathrm{CO}_{2}$ drawdown. The coupling of dust flux and $\mathrm{CO}_{2}$ in the reverse direction (i.e. glacial to interglacial) is less 
clear. Rothlisberger et al. (2004) note that only small $\mathrm{CO}_{2}$ variations accompanied large variations in the flux of non-sea salt- $\mathrm{Ca}^{2+}$ (as a proxy for dust) during glacial Antarctic warm events A1 to A4. They estimate that decreased dust deposition to the Southern Ocean during glacial to interglacial transitions accounts for not more than a 20 ppmv increase in $\mathrm{CO}_{2}$ (with changes in the North Pacific adding $<8$ ppmv $\mathrm{CO}_{2}$ ).

As yet, productivity proxies have yet to be quantified; there is no linear relationship between, for example, the Southern Ocean alkenones concentrations and palaeo-productivity. It is possible, however, to estimate some upper and lower bounds on the extent of productivity increase needed to account for the timing and fall in atmospheric $\mathrm{CO}_{2}$, as recorded in the Antarctic ice cores (Box $1)$.

Similar calculations can be made for other waters. For example, if the drawdown of $\mathrm{CO}_{2}$ was attributable to the HNLC waters of the NW Pacific as well as the Southern Ocean, then at $~ 15 \%$ of the global NPP, the estimated glacial changes to NPP and/or pump efficiency would be proportionally smaller. Regardless of whether interglacial-glacial changes in atmospheric $p \mathrm{CO}_{2}$ are due to a change in pump efficiency, a change in NPP or a combination of the two, the simplest case is for pump efficiency in the Southern Ocean to be towards the upper end of the probable range (i.e. closer to $20 \%$ than to $1 \%$ ). Lack of observational data (as opposed to modelled estimates) prevents further resolution of the terms here and we suggest this is a highpriority goal for future research.

Figure 21.

However, whereas Martinez-Garcia et al. (2009) infer that dust-forced iron fertilization has been operating in the subantarctic region over at least the last 1.1 My, the spatial distribution of LGM increases in ocean productivity does clearly vary with sector. LGM opal accumulation rates increased in the northern part of the ACC but were greatest in the Atlantic sector of the Southern Ocean, coincident with highest detrital sediment accumulation rates. Rather than of aeolian origin, much of this terrigenous flux is likely to have been of glacigenic and/or bottom watertransported origin (Diekmann, 2007; Maher and Dennis, 2001). Further, even within this sector - 
1384 much of which lies directly downwind of the S. American dust source -, it is suggested that areas 1385 of enhanced LGM productivity existed as rather localized 'hotspots' (Anderson et al., 2008), and 1386 that these 'hotspots' may reflect localized iron inputs, such as reactive (i.e. more bioavailable),

1387 nanoparticulate iron from iceberg rafting (Raiswell et al., 2008). 
BOX 1: Estimations of changes in net primary productivity and/or efficiency of the biological pump at glacial terminations.

1. Global net primary productivity (NPP) is $\sim 105 \mathrm{Pg} \mathrm{C}$ per year, with $\sim 50 \mathrm{Pg}$ of this in the oceans (e.g. Field et al., 1998). The efficiency of the biological pump is contentious (e.g., Archer and Johnson, 2000; Moore and Doney 2007; Jin et al., 2008); estimates span a wide range from $<1$ to $20 \%$ of NPP being exported, depending both on the location and definition of 'exported'. Thus, modern carbon export may lie between $0.5-10 \operatorname{PgC~} y^{-1}$.

2. From the onset of glaciations, it takes at least 10,000 years for $\mathrm{CO}_{2}$ to drop by $100 \mathrm{ppm}$, such a decrease representing $\sim 220 \mathrm{Pg}$ carbon, or $\sim 0.02 \mathrm{PgC} \mathrm{y}^{-1}$.

3. Assuming that the decrease in atmospheric $\mathrm{CO}_{2}$ was due solely to enhanced export from the Southern Ocean, bounding conditions can be established by considering two end member cases. The first end member case (see 4. below) is when NPP changes and pump efficiency is constant; the second end member case (see 5. below) is when NPP is constant and the pump efficiency changes.

4. Modern primary production in the Southern Ocean (waters south of $50^{\circ} \mathrm{S}$ ) is $\sim 2 \mathrm{PgC} y^{-1}$ (Arrigo et al., 2008). At the termination of a glacial stage, with a $1 \%$ pump efficiency, total export $=0.04 P g C y^{-1}$, i.e. the 'baseline' export of $1 \%$ of the modern NPP $(2 \mathrm{Pg})=$ $0.02 \mathrm{Pg} \mathrm{C} \mathrm{y}^{-1}$, plus the $0.02 \mathrm{Pg} \mathrm{C} \mathrm{y}^{-1}$ 'extra export' required to reduce atmospheric $\mathrm{CO}_{2}$ to its observed glacial value. This would require NPP at the glacial termination to have been $4 \mathrm{Pg} \mathrm{C} \mathrm{y}^{-1}$, i.e. a $100 \%$ increase over the modern NPP value.

5. Conversely, at a glacial termination, with $20 \%$ pump efficiency, the total carbon export of $(0.4+0.02) \mathrm{Pg} \mathrm{C}^{-1}$ would have required an NPP of $2.1 \mathrm{Pg} \mathrm{C}^{-1}$; i.e. just $a 5 \%$ increase over modern NPP.

6. In the case of constant NPP (at $2 \mathrm{Pg} \mathrm{C}^{-1}$ ), the total required glacial export in the Southern Ocean of $0.04 \mathrm{Pg} \mathrm{C}^{-1}$ indicates a pump efficiency of $1.3 \%$ ( a $30 \%$ increase over a baseline $1 \%$ efficiency), while total export of $1.22 \mathrm{Pg} \mathrm{C}^{-1}$ gives a pump efficiency of $20.3 \%$ ( 2 \% increase over a baseline $20 \%$ efficiency). 
In summary, changes in Southern Ocean marine productivity, during the later stages of the LGM, may have contributed up to half the recorded glacial fall in atmospheric $\mathrm{CO}_{2}$. These changes may have been linked directly and causally with increased S. American dust fluxes, but are also likely to reflect iron supply from other detrital sources.

\subsection{LGM dust fluxes and changes in radiative forcing?}

Dust flux data retrieved from sediment archives (e.g. figs. 8, 10a, 14) demonstrate the major, global increase in 'dustiness' at the LGM, with at least some evidence of coherent MAR increases between both hemispheres, even at sub-millennial timescales. From the terrestrial loess sequences in particular, very high dust fluxes indicate marked increases in dust source 'strength', i.e. dust supply increasing due to significant expansion of source areas. Provenance studies of loess shows that this expansion reflects desiccation and expansion of arid and semi-arid areas (such as the American Great Plains, the Russian steppe), as well as continental- (northern hemisphere) and regional-scale (southern hemisphere) glaciation, acting to supply freshly ground rock particles for deflation and transport at and beyond the ice sheet margins (Hughes, 1992). Modelling studies also indicate that expansion of dust source areas is required to simulate the observed LGM fluxes. Using linked terrestrial biosphere, dust source, and atmospheric transport models to simulate the dust cycle, Mahowald et al. (1999), for example, show that the simulated increase in high-latitude dustiness requires the expansion of unvegetated areas, especially in the high latitudes and central Asia. This expansion results from increased aridity and lowered atmospheric $\mathrm{CO}_{2}$, indicating the impact of vegetation feedbacks in modulating the atmospheric dust sources and fluxes. Visual comparison of the LGM modelled and measured dust fluxes (fig. 10), however, shows that while the dust cycle models simulate far-field dust deposition moderately well, they frequently under-estimate dust loadings close to dust sources, and over the continents in general, sometimes by up to an order of magnitude. Some of this discrepancy has been resolved by a twofold approach: firstly, by incorporating dust into a GCM and secondly, by including in dust cycle models a number of glaciogenic dust sources, designated by inversion from the palaeo-data (fig. 10b, and Mahowald et al., 2006). An important caveat is that dust cycle models do not commonly represent particles at the coarser end of the size distribution $(>10$ $\mu \mathrm{m})$. Present day observations of dust are often similarly constrained; many aerosol studies use cascade samplers with a cut-off at $2 \mu \mathrm{m}$. Thus, in making comparisons between model outputs 
and dust observations and/or archives (e.g. sediment cores), it is important that size fractions are matched (e.g. Mahowald et al., 2006). Nevertheless, current dust cycle models have yet to adequately compute deposition fluxes in regions including or in the vicinity of dust sources (as above). The converse problem is that the models appear to over-estimate dust fluxes in the Southern Ocean, where dust deposition (to the Kerguelen Plateau) is up to 2 orders of magnitude lower than in most current models (Wagener et al., 2008).

Complementing these increases in supply of dust, the enhanced transport of that dust can readily be invoked, given - for example - that the Southern Ocean westerly winds are likely weaker and/or shifted equatorward during glacial periods compared to interglacial periods (Toggweiler et al., 2006). However, enhanced transport can be ascribed not only to more vigorous atmospheric circulation. Changes in transport path and removal mechanisms are also likely to have occurred, e.g. reduced rain-out (leading to increased atmospheric residence times), shortening of trajectory from an expanded source, and/or shifting of the atmospheric jet. Such transport factors may also have resulted in regional-scale variations in dust particle size, rendering subsequent inferences of wind speed changes subject to some degree of caution. Based on changes in dust particle size, LGM increases in wind speed have previously been inferred for northern and central China, Greenland, NW Africa, southern S. America and Antarctica.

However, more complicated particle size/transport path relationships are evident, for example, for the dust record of the NW Pacific (despite its 'intermediate' position between the Chinese loess and the Greenland ice cores), and indeed across the Antarctic Plateau.

Intensified cyclonic activity in northern middle latitudes has been modelled for the LGM (e.g. Shin et al., 2003; Bush and Philander, 1999) although with some southerly displacement $\left(\sim 3^{\circ}\right)$ of the core of the jet. Depending on the reconstructed ice sheet topography (Peltier, 1994), the Laurentide ice sheet also splits the jet stream in the above-cited models; such a split might have resulted in a more directly coupled transport path from the Chinese dust sources to the Greenland ice sheet.

In radiative terms, models have indicated rather different outcomes arising from increased glacial dust fluxes. For example, enhanced glacial fluxes of dust may have increased albedo resulting in 
marked net cooling (Claquin et al. (2003); Mahowald et al. (2006)), in turn reducing convectional intensity and precipitation (Miller et al, 2004), and diminishing poleward transport of heat and moisture (Ivanochko et al., 2005). In direct contrast, Overpeck et al. (1996) suggested that high atmospheric dust loadings during glaciations may have resulted in episodic, regionalscale warming (of the order of $\sim 5^{\circ} \mathrm{C}$ ), downwind of the major Asian and ice-margin dust source regions. The modelled degree of warming was greater at progressively higher latitudes, reaching peak values $\left(+2.4{ }^{\circ} \mathrm{C}\right)$ for high-albedo (snow- and ice-covered) areas with high atmospheric dust loadings. Over such bright surfaces, the effects of dust absorption may dominate those of scattering, thus reducing short wave backscattering and enhancing long wave radiation (see section 3.2.2). The model simulations reported by Overpeck et al. (1996) also show glacial-stage warming patterns which differ markedly from the pattern of the applied, dust-induced radiative forcing. These differences likely reflect the interactive role of feedbacks, as atmospheric pressure, circulation and cloud patterns are altered, in modifying the regional energy balance. These authors note that these dust-driven radiative impacts may be under-estimated by the model, given the spatial and temporal variability of flux changes traced by the palaeo-dust record. Nor did the simulations include the radiative effects of deposited dust on snow and ice, which may significantly amplify warming effects (Peltier and Marshall, 1995; Krinner et al., 2006). Sub-millennial variability in dust fluxes may in turn reflect feedback-induced oscillations; for example, in the case of the Asian region, through modifying land-ocean thermal gradients, resultant monsoonal intensity and extent and type of vegetation cover in the semi-arid zone. Similarly, dust-induced warming in the Southern Ocean region may have caused glacial retreat in the southern S. America dust source areas, cutting off dust supply as glaciers terminated and deposited sediment in proglacial lakes rather than as unvegetated debris on outwash plains (Sugden et al., 2009).

Across a range of palaeo-dust records, it appears that dust fluxes peak just prior to Dansgaard/Oeschger oscillations, before and during Heinrich events, and just before glacial terminations (Rothlisberger et al., 2002). The Southern Ocean records suggest that up to half of the glacial-interglacial change in atmospheric $\mathrm{CO}_{2}$ can be accounted for by dust-driven changes in marine productivity. It seems possible that radiative forcing by dust can provide an additional 
key feedback, producing warming above and beyond the extensive bright surfaces - whether ice and snow or bare soil and desert - of the glacial world.

\section{Conclusions.}

Dust is important because not only can it affect climate, but the generation and transport of dust is itself extremely sensitive to climate (fig. 1, fig. 22). For the future, dust cycle models predict large changes in aeolian transport from the continents to the oceans over coming centuries, in response to anthropogenic climate change. It is thus important and timely to evaluate the extent to which changes in dust fluxes and properties may modulate or amplify global warming. Because spatial and temporal coverage of data on dust properties and emissions is limited at the present day, most of the currently reported dust budget values are based on transport models. The utility of these models and simulations is limited by uncertainties in our knowledge and understanding of dust sources and characteristics, and of atmospheric transport and dust removal and reaction processes (fig. 22). For example, regional-scale variations in dust composition, shape, particle size and surface roughness introduce significant uncertainties to the problem of modelling dust radiative forcing. At present, direct radiative forcing by dust appears to result in cooling over much of the Earth's surface; bright surfaces (such as deserts and ice and snow) are the exception, where dust can exert significant warming effects. Improved modelling of dust optical properties at solar wavelengths can only be achieved with improved data on present and past regional variations in aerosol size and shape distributions, and in iron oxide concentrations, mineralogies and mixing state.

Other types of dust cycle model are being developed in order to estimate the biogeochemical effects of dust transport to the oceans, through the supply of otherwise limited nutrients to marine phytoplankton. For example, an observational dust proxy (ocean surface concentrations of dissolved aluminium), a biogeochemical element cycling ocean model and a global dust entrainment and deposition model have recently been used in semi-independent combination to constrain dust deposition to the oceans (Han et al., 2008). However, even with major recent expansion of the ocean $\mathrm{Al}$ database, the present day spatial and temporal dust proxy coverage remains inadequate for resolving global dust climatology. This scarcity of data on dust fluxes and properties is an issue to be addressed with new field campaigns. In the case of ocean Al, new 
sampling transects across the Pacific and Indian Oceans (within the CLIVAR and GEOTRACES programs), will begin to address one aspect of this problem. However, the most robust estimates of past and present dust fluxes are likely to be achieved only with use of multiple observational datasets (at optimized spatial resolution) to constrain dust cycle models (Cakmur et al., 2006). The DIRTMAP3 data (figs. 9a and 10a) clearly delineate those regions which remain severely under-represented in terms of any observed dust fluxes for the present day and/or the LGM. Such under-represented sites include much of the southern hemisphere, both terrestrial and marine. Even for those sites encompassed by DIRTMAP3, very few data exist regarding the key dust properties associated with the known sources and fluxes. Enhanced collaboration between the modelling (radiative and biogeochemical) and data-gathering scientific communities can optimize design of new field campaigns to obtain key observational data both for the present day and for past time- (and climate-) slices.

In order to achieve the required spatial and temporal information on dust fluxes, mineralogy, particle size and shape, effective and economically-feasible means of analysis are required. In terms of mineralogy, rapid elemental analysis using $\mathrm{x}$ ray-based techniques such as particle induced x-ray emission (PIXE), x ray fluorescence and automated scanning electron microscopy (with energy dispersive $\mathrm{x}$ ray analysis, e.g. 'QEMSCAN'), continue to evolve in terms of sample preparation, and lowering of analysis cost. For the iron-bearing components of dust, often nanoscale in size and present in minor or trace concentrations, non-destructive magnetic methods may provide both a sensitive and fast means of analysis. Regarding particle size, the first challenge for improving data on dust particle size distributions, whether at present day or for the palaeo-record, is the need for expanded geographic and temporal coverage. The second requires a degree of instrumental convergence between the atmospheric and oceanic communities. In particular it is notable that in the oceanic and ice-core community particle sizes are commonly measured with instruments based on the Coulter Principle (such as the Coulter Multisizer); such instruments are rarely used in aerosol research programs. Thus it is difficult or impossible to relate the size distributions measured by different research groups.

Not only is this a problem for those measuring dust fluxes but also in turn for the modelling community. If the cut-off size of the instruments used to measure dust fluxes is poorly defined, 
then meaningful comparison subsequently with modelled dust fluxes is also hindered. Thus, if one wants to say with confidence that a model is able to reproduce the main characteristics of the dust deposition fields at present and during the LGM period, then a strategy for measurement and treatment of dust particle size distributions is needed which is agreed and implemented across both the data-gathering and dust modelling communities.

Similarly, just as convergence in analytical methods is at least desirable across the aerosol and palaeo-dust research communities, similar discussions between the aerosol, biological and palaeo-dust communities might aid development of the most appropriate analytical approaches to assessing the solubility and bioavailability of iron-bearing dusts.

The large changes in dust emissions and transport seen from the palaeo-dust record may reflect a variety of processes (fig. 22): changes in sources and source conditions; changes in vegetative cover; sub-aerial erosion of emergent continental shelves; deflation from periglacial deposits; variations in wind speed and gustiness; changed wind patterns linking sources to deposition areas; changes in deposition along the dust transport path. For the HNLC regions of the world ocean, the palaeo-dust record indicates increased dust fluxes at the LGM. The equatorial Pacific, for example, saw dust fluxes $\sim 2.5 \mathrm{x}$ higher during the last glacial stage, with dust fluxes decreasing from west to east, and towards the south. However, where sedimentation rates have been normalized by excess ${ }^{230} \mathrm{Th}$, no enhancement of ocean productivity and export production has been observed in the equatorial Pacific during the LGM. The deep-sea record of the northwest Pacific, and the Greenland ice cores, display large and rapid changes both in dust flux and particle size from interglacial into glacial climate stages. It is notable too that large dust flux changes are also evident within glacial stages, on sub-millennial timescales. Contradictory evidence currently exists for productivity and export changes at the last glacial stage in the northwest Pacific region, interpretations vary depending on the type of proxy used and its interpretation. More information is needed on the reorganization of marine ecology which results from glacial changes in ocean temperature and subsequent effects on export production.

Dust flux data remain notably scarce in the southern hemisphere, both for the present day and for the past. There is an urgent need for dust flux measurements in the Southern Oceans so that we 
can improve our understanding of dust processes in this region and to facilitate the development of atmosphere-ocean models. One practical approach to obtaining improved data coverage at the present day would be to install air samplers on the commercial and/or research vessels travelling between the Antipodes, South Africa, Antarctica and on islands in the Southern Ocean. For the past, the sedimentary record recently reported by Martinez-Garcia et al. (2009) appears to indicate up to $7 \mathrm{x}$ higher dust flux at the LGM compared with the present day. This is in contrast to the much larger increase (x 30) recorded by the ice cores of the Antarctic Plateau. In terms of productivity, the Atlantic sector of the Southern Ocean appears to have responded most to these increased LGM dust fluxes, with increased export production having occurred slowly during the early glacial period before rising to a peak at the glacial maximum. This temporal pattern suggests that dust-forced increases in Southern Ocean export production can induce significant $\mathrm{CO}_{2}$ drawdown but only during glacial maxima, and thus can account for $\sim 40-50 \mathrm{ppmv}$ drawdown of $\mathrm{CO}_{2}$ (i.e. as much as half of the total interglacial-glacial change of $\sim 100 \mathrm{ppmv}$ ). Other drivers must be responsible for the early glacial decrease in atmospheric $\mathrm{CO}_{2}$, i.e. from $280 \mathrm{ppmv}$ during the interglacial stage to the mid-glacial level of $\sim 230 \mathrm{ppmv}$. It is possible to estimate some upper and lower bounds on the extent of the productivity increase in a) the Southern Ocean and b) the Southern Ocean and NW Pacific combined, in order to account for the timing and fall in atmospheric $\mathrm{CO}_{2}$, as recorded in the Antarctic ice cores. These estimates suggest that the efficiency of the biological pump in HNLC waters is towards the upper end of the range (i.e. closer to $20 \%$ than to $1 \%$ ).

Finally, it seems clear that enhanced collaboration between the diverse scientific communities observational, modelling, biological - can only expedite resolution of the key gaps which exist in our understanding of dust sources, processes and climate impacts (fig. 22). Targeted and crosscalibrated collection of field data, both for the present day and past time- and climate-slices, seems a fundamental imperative. The aim must be to achieve not only robust measurement and/or estimation of dust fluxes across currently data-sparse regions, but also enhanced information on dust mineralogy, size, shape and surface roughness. Such data are essential both to benchmark model simulations and indeed to frame new dust, climate and biogeochemical models, including transient simulations and mesoscale modelling. Until we have a good 
1606 understanding of present-day processes, we will not be able to adequately address these

1607 processes either in the palaeo-record or with regard to the future impacts of dust on climate.

1608

1609 Acknowledgements.

1610 This paper developed from meetings of the NERC (QUEST) and INQUA-sponsored

1611 'DIRTMAP3' Working Group. BAM gratefully acknowledges support from the Royal Society

1612 (by a Royal Society Wolfson Research Merit Award), DM was supported by a University of

1613 Otago Research Grant awarded to P. Boyd, DMG is a member of the CICyT in Argentina's

1614 CONICET and was supported by IAI, Antorchas, Weizmann Institute, SECyT/UNC and

1615 FONCyT.

1616 


\section{References}

Aleinikoff, J.N., Muhs, D.R., Bettis, E.A., Johnson, W.C., Fanning, C.M. and Benton, R., 2008. Isotopic evidence for the diversity of late Quaternary loess in Nebraska: Glaciogenic and nonglaciogenic sources. Geological Society of America Bulletin, 120(11-12): 1362-1377.

Alfaro, S.C., Gaudichet, A., Gomes, L. and Maille, M., 1997. Modeling the size distribution of a soil aerosol produced by sandblasting. Journal of Geophysical Research-Atmospheres, 102(D10): 11239-11249.

Alfaro, S.C., Gaudichet, A., Gomes, L. and Maille, M., 1998. Mineral aerosol production by wind erosion: aerosol particle sizes and binding energies. Geophysical Research Letters, 25(7): 991-994.

Alfaro, S.C., Lafon, S., Rajot, J.L., Formenti, P., Gaudichet, A. and Maille, M., 2004. Iron oxides and light absorption by pure desert dust: An experimental study. Journal of Geophysical Research-Atmospheres, 109(D8): D08208.

Amo, M. and Minagawa, M., 2003. Sedimentary record of marine and terrigenous organic matter delivery to the Shatsky Rise, western North Pacific, over the last 130 kyr. Organic Geochemistry, 34(9): 1299-1312.

Andersen, K.K., Armengaud, A. and Genthon, C., 1998. Atmospheric dust under glacial and interglacial conditions. Geophysical Research Letters, 25(13): 2281-2284.

Anderson, R.F., Fleisher, M.Q. and Lao, Y., 2006. Glacial-interglacial variability in the delivery of dust to the central equatorial Pacific Ocean. Earth And Planetary Science Letters, 242(3-4): 406-414. 
Anderson, R.F., Fleisher, M.Q., Lao, Y. and Winckler, G., 2008. Modern CaCO3 preservation in equatorial Pacific sediments in the context of late-Pleistocene glacial cycles. Marine Chemistry, 111(1-2): 30-46.

Archer, D.E. and Johnson, K., 2000. A Model of the iron cycle in the ocean. Global Biogeochemical Cycles, 14(1): 269-279.

Arimoto, R., Balsam, W. and Schloesslin, C., 2002. Visible spectroscopy of aerosol particles collected on filters: iron-oxide minerals. Atmospheric Environment, 36(1): 89-96.

Arimoto, R., Duce, R.A., Ray, B.J., Ellis, W.G., Cullen, J.D. and Merrill, J.T., 1995. TraceElements in the Atmosphere over the North-Atlantic. Journal of Geophysical ResearchAtmospheres, 100(D1): 1199-1213.

Arimoto, R., Ray, B.J., Lewis, N.F., Tomza, U. and Duce, R.A., 1997. Mass-particle size distributions of atmospheric dust and the dry deposition of dust to the remote ocean. Journal of Geophysical Research-Atmospheres, 102(D13): 15867-15874.

Arrigo, K.R., van Dijken, G.L. and Bushinsky, S., 2008. Primary production in the Southern Ocean, 1997-2006. Journal of Geophysical Research-Oceans, 113(C8).

Aumont, O., Maier-Reimer, E., Blain, S. and Monfray, P., 2003. An ecosystem model of the global ocean including Fe, Si, P colimitations. Global Biogeochemical Cycles, 17(2): 1060.

Bacon, M.P., 1984. Glacial to interglacial changes in carbonate and clay sedimentation in the Atlantic Ocean estimated from Th-230 measurements. Isotope Geoscience, 2(2): 97-111. 
Baker, A.R. and Croot, P.L., 2009. Atmospheric and marine controls on aerosol iron solubility in seawater. Marine Chemistry, In Press: 10.1016/j.marchem.2008.09.003.

Baker, A.R., French, M. and Linge, K.L., 2006a. Trends in aerosol nutrient solubility along a west-east transect of the Saharan dust plume. Geophysical Research Letters, 33(7): L07805.

Baker, A.R. and Jickells, T.D., 2006. Mineral particle size as a control on aerosol iron solubility. Geophysical Research Letters, 33(17): L17608.

Baker, A.R., Jickells, T.D., Witt, M. and Linge, K.L., 2006b. Trends in the solubility of iron, aluminium, manganese and phosphorus in aerosol collected over the Atlantic Ocean. Marine Chemistry, 98(1): 43-58.

Balkanski, Y., Schulz, M., Claquin, T. and Guibert, S., 2007. Reevaluation of Mineral aerosol radiative forcings suggests a better agreement with satellite and AERONET data. Atmospheric Chemistry and Physics, 7: 81-95.

Balkanski, Y., Schulz, M., Marticorena, B., Bergametti, G., Guelle, W., Dulac, F., Moulin, C. and Lambert, C.E., 1995. Importance of the source term and of the size distribution to model the mineral dust cycle. In: S. Guerzoni and R. Chester (Editors), Impact of African Dust Across the Mediterranean Conference (ADAM). Kluwer Academic Publ, Oristano, Italy, pp. 69-76.

Barbante, C., Barnola, J.M., Becagli, S., Beer, J., Bigler, M., Boutron, C., Blunier, T., Castellano, E., Cattani, O., Chappellaz, J., Dahl-Jensen, D., Debret, M., Delmonte, B., Dick, D., Falourd, S., Faria, S., Federer, U., Fischer, H., Freitag, J., Frenzel, A., Fritzsche, 
D., Fundel, F., Gabrielli, P., Gaspari, V., Gersonde, R., Graf, W., Grigoriev, D., Hamann, I., Hansson, M., Hoffmann, G., Hutterli, M.A., Huybrechts, P., Isaksson, E., Johnsen, S., Jouzel, J., Kaczmarska, M., Karlin, T., Kaufmann, P., Kipfstuhl, S., Kohno, M., Lambert, F., Lambrecht, A., Landais, A., Lawer, G., Leuenberger, M., Littot, G., Loulergue, L., Luthi, D., Maggi, V., Marino, F., Masson-Delmotte, V., Meyer, H., Miller, H., Mulvaney, R., Narcisi, B., Oerlemans, J., Oerter, H., Parrenin, F., Petit, J.R., Raisbeck, G., Raynaud, D., Rothlisberger, R., Ruth, U., Rybak, O., Severi, M., Schmitt, J., Schwander, J., Siegenthaler, U., Siggaard-Andersen, M.L., Spahni, R., Steffensen, J.P., Stenni, B., Stocker, T.F., Tison, J.L., Traversi, R., Udisti, R., Valero-Delgado, F., van den Broeke, M.R., van de Wal, R.S.W., Wagenbach, D., Wegner, A., Weiler, K., Wilhelms, F., Winther, J.G., Wolff, E. and Members, E.C., 2006. One-to-one coupling of glacial climate variability in Greenland and Antarctica. Nature, 444(7116): 195-198.

Barbeau, K., Rue, E.L., Bruland, K.W. and Butler, A., 2001. Photochemical cycling of iron in the surface ocean mediated by microbial iron(III)-binding ligands. Nature, 413(6854): 409-413.

Basile, I., Grousset, F.E., Revel, M., Petit, J.R., Biscaye, P.E. and Barkov, N.I., 1997. Patagonian origin of glacial dust deposited in East Antarctica (Vostok and Dome C) during glacial stages 2, 4 and 6. Earth And Planetary Science Letters, 146(3-4): 573-589.

Berger, G.W., Pillans, B.J., Bruce, J.G. and McIntosh, P.D., 2002. Luminescence chronology of loess-paleosol sequences from southern South Island, New Zealand. Quaternary Science Reviews, 21(16-17): 1899-1913. 
Betzer, P.R., Carder, K.L., Duce, R.A., Merrill, J.T., Tindale, N.W., Uematsu, M., Costello, D.K., Young, R.W., Feely, R.A., Breland, J.A., Bernstein, R.E. and Greco, A.M., 1988. Long-Range Transport Of Giant Mineral Aerosol-Particles. Nature, 336(6199): 568-571.

Bidart, S., 1996. Sedimentological study of aeolian soil parent materials in the Rio Sauce Grande basin, Buenos Aires Province, Argentina. Catena, 27(3-4): 191-207.

Bigler, M., Rothlisberger, R., Lambert, F., Stocker, T.F. and Wagenbach, D., 2006. Aerosol deposited in East Antarctica over the last glacial cycle: Detailed apportionment of continental and sea-salt contributions. Journal Of Geophysical Research-Atmospheres, 111(D8): D08205.

Blain, S., Queguiner, B., Armand, L., Belviso, S., Bombled, B., Bopp, L., Bowie, A., Brunet, C., Brussaard, C., Carlotti, F., Christaki, U., Corbiere, A., Durand, I., Ebersbach, F., Fuda, J.L., Garcia, N., Gerringa, L., Griffiths, B., Guigue, C., Guillerm, C., Jacquet, S., Jeandel, C., Laan, P., Lefevre, D., Lo Monaco, C., Malits, A., Mosseri, J., Obernosterer, I., Park, Y.H., Picheral, M., Pondaven, P., Remenyi, T., Sandroni, V., Sarthou, G., Savoye, N., Scouarnec, L., Souhaut, M., Thuiller, D., Timmermans, K., Trull, T., Uitz, J., van Beek, P., Veldhuis, M., Vincent, D., Viollier, E., Vong, L. and Wagener, T., 2007. Effect of natural iron fertilization on carbon sequestration in the Southern Ocean. Nature, 446(7139): 1070-1074.

Bopp, L., Kohfeld, K.E., Le Quere, C. and Aumont, O., 2003. Dust impact on marine biota and atmospheric CO2 during glacial periods. Paleoceanography, 18(2): PA1046. 
Bory, A.J.M., Biscaye, P.E. and Grousset, F.E., 2003. Two distinct seasonal Asian source regions for mineral dust deposited in Greenland (NorthGRIP). Geophysical Research Letters, 30(4): 1167.

Bowie, A.R., Maldonado, M.T., Frew, R.D., Croot, P.L., Achterberg, E.P., Mantoura, R.F.C., Worsfold, P.J., Law, C.S. and Boyd, P.W., 2001. The fate of added iron during a mesoscale fertilisation experiment in the Southern Ocean. Deep-Sea Research Part II, 48(11-12): 2703-2743.

Bowler, J.M., 1976. Aridity In Australia - Age, Origins And Expression In Aeolian Landforms And Sediments. Earth-Science Reviews, 12(2-3): 279-310.

Boyd, P.W. and Abraham, E.R., 2001. Iron-mediated changes in phytoplankton photosynthetic competence during SOIREE. Deep-Sea Research Part Ii-Topical Studies In Oceanography, 48(11-12): 2529-2550.

Boyd, P.W., McTainsh, G., Sherlock, V., Richardson, K., Nichol, S., Ellwood, M. and Frew, R., 2004. Episodic enhancement of phytoplankton stocks in New Zealand subantarctic waters: Contribution of atmospheric and oceanic iron supply. Global Biogeochemical Cycles, 18(1): GB1029.

Boyd, P.W., Jickells, T., Law, C.S., Blain, S., Boyle, E.A., Buesseler, K.O., Coale, K.H., Cullen, J.J., de Baar, H.J.W., Follows, M., Harvey, M., Lancelot, C., Levasseur, M., Owens, N.P.J., Pollard, R., Rivkin, R.B., Sarmiento, J., Schoemann, V., Smetacek, V., Takeda, S., Tsuda, A., Turner, S. and Watson, A.J., 2007. Mesoscale iron enrichment experiments 1993-2005: Synthesis and future directions. Science, 315(5812): 612-617. 
Boyd, P.W., Mackie, D.S. and Hunter, K.A., 2009. Aerosol iron deposition to the surface ocean - Modes of iron supply and biological responses. Marine Chemistry, In Press: doi: 10.1016.1.marchem.2009.01.008.

Bradtmiller, L.I., Anderson, R.F., Fleisher, M.Q. and Burckle, L.H., 2006. Diatom productivity in the equatorial Pacific Ocean from the last glacial period to the present: A test of the silicic acid leakage hypothesis. Paleoceanography, 21(4): PA4201.

Breitbarth, E., Achterberg, E. P., Ardelan, M. V., Baker, A. R., Bucciarelli, E., Chever, F., Croot, P. L., Duggen, S., Gledhill, M., Hassell, M., Hassler, C., Hoffmann, L. J., Hunter, K. A., Hutchins, D. A., Ingri, J., Jickells, T., Lohan, M. C., Nielsdottir, M. C., Sarthou, G., Schoemann, V., Trapp, J. M.,Turner, D. R. and Ye, Y., 2009. Iron biogeochemistry across marine systems at changing times - conclusions from the workshop held in Gothenburg, Sweden (14-16 May 2008). Biogeosciences Discussion, 6, 6635-6694.

Broecker, W., 2008. Excess sediment Th-230: Transport along the sea floor or enhanced water column scavenging? Global Biogeochemical Cycles, 22(1): GB1006.

Bullard, J., Baddock, M., McTainsh, G. and Leys, J., 2008. Sub-basin scale dust source geomorphology detected using MODIS. Geophysical Research Letters, 35(15): L1504.

Bullard, J.E. and McTainsh, G.H., 2003. Aeolian-fluvial interactions in dryland environments: examples, concepts and Australia case study. Progress in Physical Geography, 27(4): 471-501.

Bullard, J.E., McTainsh, G.H. and Pudmenzky, C., 2007. Factors affecting the nature and rate of dust production from natural dune sands. Sedimentology, 54(1): 169-182. 
Bush, A.B.G. and Philander, S.G.H., 1999. The climate of the Last Glacial Maximum: Results from a coupled atmosphere-ocean general circulation model. Journal Of Geophysical Research-Atmospheres, 104(D20): 24509-24525.

Cakmur, R.V., Miller, R.L., Perlwitz, J., Geogdzhayev, I.V., Ginoux, P., Koch, D., Kohfeld, K.E., Tegen, I. and Zender, C.S., 2006. Constraining the magnitude of the global dust cycle by minimizing the difference between a model and observations. Journal Of Geophysical Research-Atmospheres, 111(D6): D06207.

Carter-Stiglitz, B., Banerjee, S.K., Gourlan, A. and Oches, E., 2006. A multi-proxy study of Argentina loess: Marine oxygen isotope stage 4 and 5 environmental record from pedogenic hematite. Palaeogeography Palaeoclimatology Palaeoecology, 239(1-2): 4562.

Chase, Z., Anderson, R.F. and Fleisher, M.Q., 2001. Evidence from authigenic uranium for increased productivity of the glacial Subantarctic Ocean. Paleoceanography, 16(5): 468478.

Chase, Z., Anderson, R.F., Fleisher, M.Q. and Kubik, P.W., 2003. Accumulation of biogenic and lithogenic material in the Pacific sector of the Southern Ocean during the past 40,000 years. Deep-Sea Research Part II, 50(3-4): 799-832.

Chiapello, I., Bergametti, G., Chatenet, B., Bousquet, P., Dulac, F. and Soares, E.S., 1997. Origins of African dust transported over the northeastern tropical Atlantic. Journal of Geophysical Research-Atmospheres, 102(D12): 13701-13709. 
Chin, M., Rood, R.B., Lin, S.J., Muller, J.F. and Thompson, A.M., 2000. Atmospheric sulfur cycle simulated in the global model GOCART: Model description and global properties. Journal Of Geophysical Research-Atmospheres, 105(D20): 24671-24687.

Chung, C.E., Ramanathan, V., Kim, D. and Podgorny, I.A.. 2005. Global anthropogenic aerosol direct forcing derived from satellite and ground-based observations. Journal of Geophysical Research, 110, D24207, doi: 10.1029/2005JD00635.

Claquin, T., Roelandt, C., Kohfeld, K.E., Harrison, S.P., Tegen, I., Prentice, I.C., Balkanski, Y., Bergametti, G., Hansson, M., Mahowald, N., Rodhe, H. and Schulz, M., 2003. Radiative forcing of climate by ice-age atmospheric dust. Climate Dynamics, 20(2-3): 193-202.

Claquin, T., Schulz, M. and Balkanski, Y.J., 1999. Modeling the mineralogy of atmospheric dust sources. Journal Of Geophysical Research-Atmospheres, 104(D18): 22243-22256.

Coale, K.H., Johnson, K.S., Chavez, F.P., Buesseler, K.O., Barber, R.T., Brzezinski, M.A., Cochlan, W.P., Millero, F.J., Falkowski, P.G., Bauer, J.E., Wanninkhof, R.H., Kudela, R.M., Altabet, M.A., Hales, B.E., Takahashi, T., Landry, M.R., Bidigare, R.R., Wang, X.J., Chase, Z., Strutton, P.G., Friederich, G.E., Gorbunov, M.Y., Lance, V.P., Hilting, A.K., Hiscock, M.R., Demarest, M., Hiscock, W.T., Sullivan, K.F., Tanner, S.J., Gordon, R.M., Hunter, C.N., Elrod, V.A., Fitzwater, S.E., Jones, J.L., Tozzi, S., Koblizek, M., Roberts, A.E., Herndon, J., Brewster, J., Ladizinsky, N., Smith, G., Cooper, D., Timothy, D., Brown, S.L., Selph, K.E., Sheridan, C.C., Twining, B.S. and Johnson, Z.I., 2004. Southern ocean iron enrichment experiment: Carbon cycling in high- and low-Si waters. Science, 304(5669): 408-414. 
Coale, K.H., Johnson, K.S., Fitzwater, S.E., Gordon, R.M., Tanner, S., Chavez, F.P., Ferioli, L., Sakamoto, C., Rogers, P., Millero, F., Steinberg, P., Nightingale, P., Cooper, D., Cochlan, W.P., Landry, M.R., Constantinou, J., Rollwagen, G., Trasvina, A. and Kudela, R., 1996. A massive phytoplankton bloom induced by an ecosystem-scale iron fertilization experiment in the equatorial Pacific Ocean. Nature, 383(6600): 495-501.

Cornell, R.M. and Schwertmann, U., 2003. The Iron Oxides: Structure, properties, reactions, occurences and uses. Wiley-VCH, Weinheim, $664 \mathrm{pp}$.

Cwiertny, D.M., Young, M.A. and Grassian, V.H., 2008. Chemistry and photochemistry of mineral dust aerosol. Annual Review of Physical Chemistry, 59: 27-51.

Darwin, C., 1846. An account of the fine dust which often falls on vessels in the Atlantic Ocean. Quarterly Journal of the Geological Society of London, 1846(1): 26-30.

de Baar, H.J.W., Boyd, P.W., Coale, K.H., Landry, M.R., Tsuda, A., Assmy, P., Bakker, D.C.E., Bozec, Y., Barber, R.T., Brzezinski, M.A., Buesseler, K.O., Boye, M., Croot, P.L., Gervais, F., Gorbunov, M.Y., Harrison, P.J., Hiscock, W.T., Laan, P., Lancelot, C., Law, C.S., Levasseur, M., Marchetti, A., Millero, F.J., Nishioka, J., Nojiri, Y., van Oijen, T., Riebesell, U., Rijkenberg, M.J.A., Saito, H., Takeda, S., Timmermans, K.R., Veldhuis, M.J.W., Waite, A.M. and Wong, C.S., 2005. Synthesis of iron fertilization experiments: From the iron age in the age of enlightenment. Journal of Geophysical Research-Oceans, 110(C9): C09s16. 
de Baar, H.J.W., Gerringa, L.J.A., Laan, P. and Timmermans, K.R., 2008. Efficiency of carbon removal per added iron in ocean iron fertilization. Marine Ecology-Progress Series, 364: 269-282.

de Menocal, P.B., Ruddiman, W.F. and Pokras, E.M., 1993. Influences of high-latitude and lowlatitude processes on African terrestrial climate - Pleistocene eolian records from equatorial Atlantic Ocean Drilling Program Site-663. Paleoceanography, 8(2): 209-242.

Delmonte, B., Andersson, P.S., Schöberg, H., Hansson, M., Petit, J.R., Delmas, R., Gaiero, D.M., Maggi, V. and Frezzotti, M., 2009. Geographic provenance of aeolian dust in East Antarctica during Pleistocene glaciations: preliminary results from Talos Dome and comparison with East Antarctic and new Andean ice core data. Quaternary Science Reviews, In Press.

Delmonte, B., Basile-Doelsch, I., Petit, J.R., Maggi, V., Revel-Rolland, M., Michard, A., Jagoutz, E. and Grousset, F., 2004. Comparing the Epica and Vostok dust records during the last 220,000 years: stratigraphical correlation and provenance in glacial periods. Earth-Science Reviews, 66(1-2): 63-87.

Delmonte, B., Delmas, R.J. and Petit, J.R., 2008. Comment on "Dust provenance in Antarctic ice during glacial periods: From where in southern South America?" by D. M. Gaiero. Geophysical Research Letters, 35(8): L08707.

Desboeufs, K.V., Sofikitis, A., Losno, R., Colin, J.L. and Ausset, P., 2005. Dissolution and solubility of trace metals from natural and anthropogenic aerosol particulate matter. Chemosphere, 58(2): 195-203. 
Dezileau, L., Bareille, B. and Reyss, J.L., 2003. The Pa-231/Th-230 ratio as a proxy for past changes in opal fluxes in the Indian sector of the Southern Ocean. Marine Chemistry, 81(3-4): 105-117.

Diekmann, B., 2007. Sedimentary patterns in the late Quaternary Southern Ocean. Deep-Sea Research Part II, 54(21-22): 2350-2366.

Diekmann, B. and Kuhn, G., 2002. Sedimentary record of the mid-Pleistocene climate transition in the southeastern South Atlantic (ODP Site 1090). Palaeogeography Palaeoclimatology Palaeoecology, 182(3-4): 241-258.

Ding, Z.L., Ranov, V., Yang, S.L., Finaev, A., Han, J.M. and Wang, G.A., 2002. The loess record in southern Tajikistan and correlation with Chinese loess. Earth And Planetary Science Letters, 200(3-4): 387-400.

Dubovik, O., Lapyonok, T., Kaufman, Y.J., Chin, M., Ginoux, P., Kahn, R.A. and Sinyuk, A., 2008. Retrieving global aerosol sources from satellites using inverse modeling. Atmospheric Chemistry and Physics, 8(2): 209-250.

Duce, R.A., Liss, P.S., Merrill, J.T., Atlas, E.L., Buat-Menard, P., Hicks, B.B., Miller, J.M., Prospero, J.M., Arimoto, R., Church, T.M., Ellis, W., Galloway, J.N., Hansen, L., Jickells, T.D., Knap, A.H., Reinhardt, K.H., Schneider, B., Soudine, A., Tokos, J.J., Tsunogai, S., Wollast, R. and Zhou, M., 1991. The atmospheric input of trace species to the world ocean. Global Biogeochemical Cycles, 5(3): 193-259. 
Duce, R.A., Unni, C.K., Ray, B.J., Prospero, J.M. and Merrill, J.T., 1980. Long-range atmospheric transport of soil dust from Asia to the tropical North Pacific: temporal variability. Science, 209(4464): 1522-4.

Dulhunty, J.A., 1982. Holocene sedimentary environments in Lake Eyre, South-Australia. Journal of the Geological Society of Australia, 29(3-4): 437-442.

Eden, D.N. and Hammond, A.P., 2003. Dust accumulation in the New Zealand region since the last glacial maximum. Quaternary Science Reviews, 22(18-19): 2037-2052.

Engelstaedter, S., Kohfeld, K.E., Tegen, I. and Harrison, S.P., 2003. Controls of dust emissions by vegetation and topographic depressions: An evaluation using dust storm frequency data. Geophysical Research Letters, 30(6): L1294.

Engelstaedter, S., Tegen, I. and Washington, R., 2006. North African dust emissions and transport. Earth-Science Reviews, 79(1-2): 73-100.

Engelstaedter, S. and Washington, R., 2007. Atmospheric controls on the annual cycle of North African dust. Journal of Geophysical Research-Atmospheres, 112(D3): D03103.

EPICA Community Members, 2004. Eight glacial cycles from an Antarctic ice core. Nature, 429(6992): 623-628.

Falkowski, P.G., 1997. Evolution of the nitrogen cycle and its influence on the biological sequestration of CO2 in the ocean. Nature, 387(6630): 272-275. 
Field, C.B., Behrenfeld, M.J., Randerson, J.T. and Falkowski, P., 1998. Primary production of the biosphere: Integrating terrestrial and oceanic components. Science, 281(5374): 237 240.

Fischer, H., Fundel, F., Ruth, U., Twarloh, B., Wegner, A., Udisti, R., Becagli, S., Castellano, E., Morganti, A., Severi, M., Wolff, E., Littot, G., Rothlisberger, R., Mulvaney, R., Hutterli, M.A., Kaufmann, P., Federer, U., Lambert, F., Bigler, M., Hansson, M., Jonsell, U., de Angelis, M., Boutron, C., Siggaard-Andersen, M.L., Steffensen, J.P., Barbante, C., Gaspari, V., Gabrielli, P. and Wagenbach, D., 2007a. Reconstruction of millennial changes in dust emission, transport and regional sea ice coverage using the deep EPICA ice cores from the Atlantic and Indian Ocean sector of Antarctica. Earth And Planetary Science Letters, 260(1-2): 340-354.

Fischer, H., Siggaard-Andersen, M.L., Ruth, U., Rothlisberger, R. and Wolff, E., $2007 \mathrm{~b}$. Glacial/interglacial changes in mineral dust and sea-salt records in polar ice cores: Sources, transport, and deposition. Reviews of Geophysics, 45(1): RG1002.

Francois, R. and Bacon, M.P., 1991. Variations in terrigenous input into the deep equatorial Atlantic during the past 24,000 years. Science, 251(5000): 1473-1476.

Francois, R., Frank, M., van der Loeff, M.M.R. and Bacon, M.P., 2004. Th-230 normalization: An essential tool for interpreting sedimentary fluxes during the late Quaternary. Paleoceanography, 19(1): PA1018.

Frechen, M. and Dodonov, A.E., 1998. Loess chronology of the Middle and Upper Pleistocene in Tadjikistan. Geologische Rundschau, 87(1): 2-20. 
Frechen, M., Horvath, E. and Gabris, G., 1997. Geochronology of Middle and Upper Pleistocene Loess sections in Hungary. Quaternary Research, 48(3): 291-312.

Fung, I.Y., Meyn, S.K., Tegen, I., Doney, S.C., John, J.G. and Bishop, J.K.B., 2000. Iron supply and demand in the upper ocean. Global Biogeochemical Cycles, 14(1): 281-295.

Gabric, A.J., Cropp, R., Ayers, G.P., McTainsh, G. and Braddock, R., 2002. Coupling between cycles of phytoplankton biomass and aerosol optical depth as derived from SeaWiFS time series in the Subantarctic Southern Ocean. Geophysical Research Letters, 29(7): 1112.

Gaiero, D.M., 2007. Dust provenance in Antarctic ice during glacial periods: From where in southern South America? Geophysical Research Letters 34, L17707.

Gaiero, D.M., Brunet, F., Probst, J.L. and Depetris, P.J., 2007. A uniform isotopic and chemical signature of dust exported from Patagonia: Rock sources and occurrence in southern environments. Chemical Geology, 238(1-2): 107-120.

Gaiero, D.M., Depetris, P.J., Probst, J.L., Bidart, S.M. and Leleyter, L., 2004. The signature of river- and wind-borne materials exported from Patagonia to the southern latitudes: a view from REEs and implications for paleoclimatic interpretations. Earth And Planetary Science Letters, 219(3-4): 357-376.

Gaiero, D.M., Probst, J.L., Depetris, P.J., Bidart, S.M. and Leleyter, L., 2003. Iron and other transition metals in Patagonian riverborne and windborne materials: Geochemical control and transport to the southern South Atlantic Ocean. Geochimica Et Cosmochimica Acta, 67(19): 3603-3623. 
Gao, Y., Arimoto, R., Duce, R.A., Zhang, X.Y., Zhang, G.Y., An, Z.S., Chen, L.Q., Zhou, M.Y. and Gu, D.Y., 1997. Temporal and spatial distributions of dust and its deposition to the China Sea. Tellus Series B-Chemical and Physical Meteorology, 49(2): 172-189.

Gao, Y., Arimoto, R., Zhou, M.Y., Merrill, J.T. and Duce, R.A., 1992. Relationships between the dust concentrations over eastern Asia and the remote North Pacific. Journal Of Geophysical Research-Atmospheres, 97(D9): 9867-9872.

Garstang, M., Tyson, P.D., Swap, R., Edwards, M., Kallberg, P. and Lindesay, J.A., 1996. Horizontal and vertical transport of air over southern Africa. Journal Of Geophysical Research-Atmospheres, 101(D19): 23721-23736.

Gasso, S. and Stein, A.F., 2007. Does dust from Patagonia reach the sub-Antarctic Atlantic ocean? Geophysical Research Letters, 34(1): L01801.

Gebhardt, H., Sarnthein, M., Grootes, P.M., Kiefer, T., Kuehn, H., Schmieder, F. and Rohl, U., 2008. Paleonutrient and productivity records from the subarctic North Pacific for Pleistocene glacial terminations I to V. Paleoceanography, 23(4): 21.

Gillette, D., 1978. Wind-tunnel simulation of erosion of soil - effect of soil texture, sandblasting, wind speed, and soil consolidation on dust production. Atmospheric Environment, 12(8): $1735-1743$

Ginoux, P., Chin, M., Tegen, I., Prospero, J.M., Holben, B., Dubovik, O. and Lin, S.J., 2001. Sources and distributions of dust aerosols simulated with the GOCART model. Journal of Geophysical Research-Atmospheres, 106(D17): 20255-20273. 
Ginoux, P., Prospero, J.M., Torres, O. and Chin, M., 2004. Long-term simulation of global dust distribution with the GOCART model: correlation with North Atlantic Oscillation. Environmental Modelling \& Software, 19(2): 113-128.

Gomes, L. and Gillette, D.A., 1993. A comparison of characteristics of aerosol from dust storms in central-asia with soil-derived dust from other regions. Atmospheric Environment Part a-General Topics, 27(16): 2539-2544.

Grini, A. and Zender, C.S., 2004. Roles of saltation, sandblasting, and wind speed variability on mineral dust aerosol size distribution during the Puerto Rican Dust Experiment (PRIDE). Journal of Geophysical Research-Atmospheres, 109(D7): D07202.

Grousset, F.E., Biscaye, P.E., Revel, M., Petit, J.R., Pye, K., Joussaume, S. and Jouzel, J., 1992. Antarctic (Dome C) Ice-Core Dust At 18 Ky Bp - Isotopic Constraints On Origins. Earth And Planetary Science Letters, 111(1): 175-182.

Han, Q., Moore, J.K., Zender, C., Measures, C. and Hydes, D., 2008. Constraining oceanic dust deposition using surface ocean dissolved Al. Global Biogeochemical Cycles, 22(2): GB2003.

Harrison, S.P., Kohfeld, K.E., Roelandt, C. and Claquin, T., 1999. The role of dust in climate changes today, at the last glacial maximum and in the future, International Conference of Loessfest 99. Elsevier Science Bv, Bonn, Germany, pp. 43-80.

Hays, J.D. and Morley, J.J., 2003. The Sea of Okhotsk: A window on the ice age ocean. DeepSea Research Part I, 50(12): 1481-1506. 
Haywood, J.M., Allan, R.P., Culverwell, I., Slingo, T., Milton, S., Edwards, J. and Clerbaux, N., 2005. Can desert dust explain the outgoing longwave radiation anomaly over the Sahara during July 2003? Journal of Geophysical Research-Atmospheres, 110(D5): D05105.

Herman, J.R., Bhartia, P.K., Torres, O., Hsu, C., Seftor, C. and Celarier, E., 1997. Global distribution of UV-absorbing aerosols from Nimbus 7/TOMS data. Journal Of Geophysical Research-Atmospheres, 102(D14): 16911-16922.

Herman, J.R. and Celarier, E.A., 1997. Earth surface reflectivity climatology at 340-380 nm from TOMS data. Journal of Geophysical Research-Atmospheres, 102(D23): 2800328011.

Hesse, P.P., 1994. The Record of Continental Dust from Australia in Tasman Sea Sediments. Quaternary Science Reviews, 13(3): 257-272.

Hesse, P.P., 1997. Mineral magnetic 'tracing' of aeolian dust in southwest Pacific sediments. Palaeogeography Palaeoclimatology Palaeoecology, 131(3-4): 327-353.

Hesse, P.P., Humphreys, G.S., Smith, B.L., Campbell, J. and Peterson, E.K., 2003. Accumulation and preservation of loess deposits in the Central Tablelands of New South Wales. In: I.C. Roach (Editor), Advances in Regolith. CRC LEME, Canberra, pp. 170173.

Hesse, P.P. and McTainsh, G.H., 1999. Last glacial maximum to early holocene wind strength in the mid-latitudes of the Southern Hemisphere from aeolian dust in the Tasman Sea. Quaternary Research, 52(3): 343-349. 
Hesse, P.P. and McTainsh, G.H., 2003. Australian dust deposits: modern processes and the Quaternary record. Quaternary Science Reviews, 22(18-19): 2007-2035.

Honda, M.C., Kawakami, H., Sasaoka, K., Watanabe, S. and Dickey, T., 2006. Quick transport of primary produced organic carbon to the ocean interior. Geophysical Research Letters, 33(16): L16603.

Honjo, S., Dymond, J., Collier, R. and Manganini, S.J., 1995. Export production of particles to the interior of the equatorial Pacific Ocean during the 1992 EQPAC experiment. DeepSea Research Part II, 42(2-3): 831-870.

Hovan, S.A., Rea, D.K. and Pisias, N., 1991. Late Pleistocene Continental Climate and Oceanic Variability Recorded in Northwest Pacific Sediments. Paleoceanography, 6(3): 349-370.

Hovan, S.A., Rea, D.K., Pisias, N.G. and Shackleton, N.J., 1989. A direct link between the China loess and marine delta-O-18 records - aeolian flux to the North Pacific. Nature, 340(6231): 296-298.

Hughes, T., 1992. Abrupt climatic change related to unstable ice-sheet dynamics: toward a new paradigm. Palaeogeography Palaeoclimatology Palaeoecology, 97(3): 203-234.

Husar, R.B., Prospero, J.M. and Stowe, L.L., 1997. Characterization of tropospheric aerosols over the oceans with the NOAA advanced very high resolution radiometer optical thickness operational product. Journal Of Geophysical Research-Atmospheres, 102(D14): 16889-16909. 
IPCC, 2001a. Penner, J., Andreae, M., Annegarn, H., Barrie, L., Feichter, J., Hegg, D., Jayaraman, A., Leaitch, R., Murphy, D., Nganga, J., Pitari, G., 2001: Aerosols, their Direct and Indirect Effects. In: Climate Change 2001: The Scientific Basis. Contribution of Working Group I to the Third Assessment Report of the Intergovernmental Panel on Climate Change [Houghton, J.T.,Y. Ding, D.J. Griggs, M. Noguer, P.J. van der Linden, X. Dai, K. Maskell, and C.A. Johnson (eds.)]. Cambridge University Press, Cambridge, United Kingdom and New York, NY, USA.

IPCC, 2001b. V. Ramaswamy, V., Boucher, O., Haigh, J., Hauglustaine, D., Haywood, J., Myhre, G., Nakajima, T., Shi, G.Y., Solomon, S., 2001: Radiative Forcing of Climate Change. In: Climate Change 2001: The Scientific Basis. Contribution of Working Group I to the Third Assessment Report of the Intergovernmental Panel on Climate Change [Houghton, J.T.,Y. Ding, D.J. Griggs, M. Noguer, P.J. van der Linden, X. Dai, K. Maskell, and C.A. Johnson (eds.)]. Cambridge University Press, Cambridge, United Kingdom and New York, NY, USA.

IPCC, 2007. Forster, P., V. Ramaswamy, P. Artaxo, T. Berntsen, R. Betts, D.W. Fahey, J. Haywood, J. Lean, D.C. Lowe, G. Myhre, J. Nganga, R. Prinn, G. Raga, M. Schulz and R. Van Dorland, 2007: Changes in Atmospheric Constituents and in Radiative Forcing. In: Climate Change 2007: The Physical Science Basis. Contribution of Working Group I to the Fourth Assessment Report of the Intergovernmental Panel on Climate Change [Solomon, S., D. Qin, M. Manning, Z. Chen, M. Marquis, K.B. Averyt, M.Tignor and H.L. Miller (eds.)]. Cambridge University Press, Cambridge, United Kingdom and New York, NY, USA. 
Iriondo, M., 2000. Patagonian dust in Antarctica. Quaternary International, 68: 83-86.

Ivanochko, T.S., Ganeshram, R.S., Brummer, G.J.A., Ganssen, G., Jung, S.J.A., Moreton, S.G. and Kroon, D., 2005. Variations in tropical convection as an amplifier of global climate change at the millennial scale. Earth And Planetary Science Letters, 235(1-2): 302-314.

Jaccard, S.L., Haug, G.H., Sigman, D.M., Pedersen, T.F., Thierstein, H.R. and Rohl, U., 2005. Glacial/interglacial changes in subarctic North Pacific stratification. Science, 308(5724): 1003-1006.

Janecek, T.R., 1985. Eolian sedimentation in the northwest Pacific Ocean - a preliminary examination of the data from Deep-Sea Drilling Project Site-576 and Site-578. Initial Reports of the Deep Sea Drilling Project, 86(NOV): 589-603.

Jeong, G.Y., Hillier, S. and Kemp, R.A., 2008. Quantitative bulk and single-particle mineralogy of a thick Chinese loess-paleosol section: implications for loess provenance and weathering. Quaternary Science Reviews, 27(11-12): 1271-1287.

Ji, J.F., Chen, J., Balsam, W., Lu, H.Y., Sun, Y.B. and Xu, H.F., 2004. High resolution hematite/goethite records from Chinese loess sequences for the last glacial-interglacial cycle: Rapid climatic response of the East Asian Monsoon to the tropical Pacific. Geophysical Research Letters, 31(3): L03207.

Jickells, T.D., An, Z.S., Andersen, K.K., Baker, A.R., Bergametti, G., Brooks, N., Cao, J.J., Boyd, P.W., Duce, R.A., Hunter, K.A., Kawahata, H., Kubilay, N., laRoche, J., Liss, P.S., Mahowald, N., Prospero, J.M., Ridgwell, A.J., Tegen, I. and Torres, R., 2005. Global iron 
connections between desert dust, ocean biogeochemistry, and climate. Science, 308(5718): 67-71.

Jin, X., Gruber, N., Frenzel, H., Doney, S.C. and McWilliams, J.C., 2008. The impact on atmospheric $\mathrm{CO} 2$ of iron fertilization induced changes in the ocean's biological pump. Biogeosciences, 5(2): 385-406.

Johansen, A.M. and Key, J.M., 2006. Photoreductive dissolution of ferrihydrite by methanesulfinic acid: Evidence of a direct link between dimethylsulfide and ironbioavailability. Geophysical Research Letters, 33(14): L14818.

Johansen, A.M., Siefert, R.L. and Hoffmann, M.R., 2000. Chemical composition of aerosols collected over the tropical North Atlantic Ocean. Journal of Geophysical ResearchAtmospheres, 105(D12): 15277-15312.

Johnson, K.S., Gordon, R.M. and Coale, K.H., 1997. What controls dissolved iron concentrations in the world ocean? Marine Chemistry, 57(3-4): 137-161.

Journet, E., Desboeufs, K.V., Caquineau, S. and Colin, J.L., 2008. Mineralogy as a critical factor of dust iron solubility. Geophysical Research Letters, 35(7): L07805.

Jouzel, J., Masson-Delmotte, V., Cattani, O., Dreyfus, G., Falourd, S., Hoffmann, G., Minster, B., Nouet, J., Barnola, J.M., Chappellaz, J., Fischer, H., Gallet, J.C., Johnsen, S., Leuenberger, M., Loulergue, L., Luethi, D., Oerter, H., Parrenin, F., Raisbeck, G., Raynaud, D., Schilt, A., Schwander, J., Selmo, E., Souchez, R., Spahni, R., Stauffer, B., Steffensen, J.P., Stenni, B., Stocker, T.F., Tison, J.L., Werner, M. and Wolff, E.W., 2007. 
Orbital and millennial Antarctic climate variability over the past 800,000 years. Science, 317(5839): 793-796.

Kahnert, M., Nousiainen, T. and Raisanen, P., 2007. Mie simulations as an error source in mineral aerosol radiative forcing calculations. Quarterly Journal of the Royal Meteorological Society, 133(623): 299-307.

Kaufman, Y.J., Tanre, D. and Boucher, O., 2002. A satellite view of aerosols in the climate system. Nature, 419(6903): 215-223.

Kawahata, H., Okamoto, T., Matsumoto, E. and Ujiie, H., 2000. Fluctuations of eolian flux and ocean productivity in the mid-latitude North Pacific during the last 200 kyr. Quaternary Science Reviews, 19(13): 1279-1291.

Kemp, R.A., Toms, P.S., King, M. and Krohling, D.M., 2004. The pedosedimentary evolution and chronology of Tortugas, a Late Quaternary type-site of the northern Pampa, Argentina. Quaternary International, 114: 101-112.

Kohfeld, K.E. and Harrison, S.P., 2001. DIRTMAP: the geological record of dust. Earth-Science Reviews, 54(1-3): 81-114.

Kohfeld, K.E. and Harrison, S.P., 2003. Glacial-interglacial changes in dust deposition on the Chinese Loess Plateau. Quaternary Science Reviews, 22(18-19): 1859-1878.

Kohfeld, K.E., Le Quere, C., Harrison, S.P. and Anderson, R.F., 2005. Role of marine biology in glacial-interglacial CO2 cycles. Science, 308(5718): 74-78. 
Koren, I., Kaufman, Y.J., Washington, R., Todd, M., Rudich, Y., Martins, J.V. and Rosenfeld, D., 2007. The Bodele depression: a single spot in the Sahara that provides most of the mineral dust to the Amazon forest. Environmental Research Letters, 1: 014005.

Krinner, G. and Genthon, C., 2003. Tropospheric transport of continental tracers towards Antarctica under varying climatic conditions. Tellus Series B-Chemical and Physical Meteorology, 55(1): 54-70.

Krinner G., Boucher, O. and Balkanski, Y.. 2006. Reduced glacial ice sheet extent in Northern Asia and Alaska owing to deposition of mineral dust on snow, Geophysical Research Letters, 10.1007/s00382-006-0159-z.

Krohling, D.M. and Iriondo, M., 1999. Upper Quaternary Palaeoclimates of the Mar Chiquita area, North Pampa, Argentina. Quaternary International, 57-8: 149-163.

Kubilay, N., Oguz, T., Kocak, M. and Torres, O., 2005. Ground-based assessment of Total Ozone Mapping Spectrometer (TOMS) data for dust transport over the northeastern Mediterranean. Global Biogeochemical Cycles, 19(1): GB1022.

Kukla, G., 1987. Loess stratigraphy in central China. Quaternary Science Reviews, 6(3-4): 191219.

Kumar, N., Anderson, R.F., Mortlock, R.A., Froelich, P.N., Kubik, P., Dittrichhannen, B. and Suter, M., 1995. Increased biological productivity and export production in the glacial Southern Ocean. Nature, 378(6558): 675-680. 
2102

2103

2104

2105

2106

2107

2108

2109

2110

2111

2112

2113

2114

Lafon, S., Sokolik, I.N., Rajot, J.L., Caquineau, S. and Gaudichet, A., 2006. Characterization of iron oxides in mineral dust aerosols: Implications for light absorption. Journal Of Geophysical Research-Atmospheres, 111(D21): D21207.

Lambert, F., Delmonte, B., Petit, J.R., Bigler, M., Kaufmann, P., Hutterli, M.A., Stocker, T.F., Ruth, U., Steffensen, J.P. and Maggi, V., 2008. Dust-climate couplings over the past 800,000 years from the EPICA Dome C ice core. Nature, 452(7187): 616-619.

Latimer, J.C. and Filippelli, G.M., 2001. Terrigenous input and paleoproductivity in the Southern Ocean. Paleoceanography, 16(6): 627-643.

Lee, C.H., Park, C.B. and Kim, J.H., 2004. Asian dust measurement with Mie-scattering Lidar at Suwon, Korea in the Spring of 2000-2004. In: G.G. Matvienko (Editor), Conference on Optical Technologies for Atmospheric, Ocean, and Environmental Studies. Spie-Int Soc Optical Engineering, Beijing, PEOPLES R CHINA, pp. 99-109.

Lefevre, N. and Watson, A.J., 1999. Modeling the geochemical cycle of iron in the oceans and its impact on atmospheric $\mathrm{CO} 2$ concentrations. Global Biogeochemical Cycles, 13(3): 727-736.

Lehmkuhl, F. and Owen, L.A., 2005. Late Quaternary glaciation of Tibet and the bordering mountains: a review. Boreas, 34(2): 87-100.

Li, F., Ginoux, P. and Ramaswamy, V., 2008. Distribution, transport, and deposition of mineral dust in the Southern Ocean and Antarctica: Contribution of major sources. Journal of Geophysical Research-Atmospheres, 113(D10): D10207. 
2122

2123

Lim, J. and Matsumoto, E., 2008. Fine aeolian quartz records in Cheju Island, Korea, during the last 6500 years and pathway change of the westerlies over east Asia. Journal Of Geophysical Research-Atmospheres, 113(D8): D08106.

Lisiecki, L.E. and Raymo, M.E., 2005. A Pliocene-Pleistocene stack of 57 globally distributed benthic delta O-18 records. Paleoceanography, 20(1): PA1003.

Loubere, P., Mekik, F., Francois, R. and Pichat, S., 2004. Export fluxes of calcite in the eastern equatorial Pacific from the Last Glacial Maximum to present. Paleoceanography, 19(2).

Lunt, D.J. and Valdes, P.J., 2002. Dust deposition and provenance at the Last Glacial Maximum and present day. Geophysical Research Letters, 29(22): L2085.

Luo, C., Mahowald, N., Bond, T., Chuang, P.Y., Artaxo, P., Siefert, R., Chen, Y. and Schauer, J., 2008. Combustion iron distribution and deposition. Global Biogeochemical Cycles, 22(1): GB1012.

Luo, C., Mahowald, N.M. and del Corral, J., 2003. Sensitivity study of meteorological parameters on mineral aerosol mobilization, transport, and distribution. Journal Of Geophysical Research-Atmospheres, 108(D15): D154447.

Luthi, D., Le Floch, M., Bereiter, B., Blunier, T., Barnola, J.M., Siegenthaler, U., Raynaud, D., Jouzel, J., Fischer, H., Kawamura, K. and Stocker, T.F., 2008. High-resolution carbon dioxide concentration record 650,000-800,000 years before present. Nature, 453(7193): $379-382$ 
Lyle, M., Pisias, N., Paytan, A., Martinez, J.I. and Mix, A., 2007. Reply to comment by R. Francois et al. on "Do geochemical estimates of sediment focusing pass the sediment test in the equatorial Pacific?": Further explorations of Th-230 normalization. Paleoceanography, 22(1): PA1217.

Machalett, B., Oches, E.A., Frechen, M., Zoller, L., Hambach, U., Mavlyanova, N.G., Markovic, S.B. and Endlicher, W., 2008. Aeolian dust dynamics in central Asia during the Pleistocene: Driven by the long-term migration, seasonality, and permanency of the Asiatic polar front. Geochemistry Geophysics Geosystems, 9: Q08q09.

Mackie, D.S., Boyd, P.W., Hunter, K.A. and McTainsh, G.H., 2005. Simulating the cloud processing of iron in Australian dust: $\mathrm{pH}$ and dust concentration. Geophysical Research Letters, 32(6): L06809.

Mackie, D.S., Boyd, P.W., McTainsh, G.H., Tindale, N.W., Westberry, T.K. and Hunter, K.A., 2008. Biogeochemistry of iron in Australian dust: From eolian uplift to marine uptake. Geochemistry Geophysics Geosystems, 9: Q03Q08.

Maher, B.A., 2007. Environmental magnetism and climate change. Contemporary Physics, 48(5): $247-274$.

Maher, B.A., 2009. Sourcing and quantifying aeolian dust in the Quaternary sedimentary record, Southern Ocean, EGU General Assembly 2009, pp. EGU2009-12531.

Maher, B.A., Alekseev, A. and Alekseeva, T., 2003. Magnetic mineralogy of soils across the Russian Steppe: climatic dependence of pedogenic magnetite formation. Palaeogeography Palaeoclimatology Palaeoecology, 201(3-4): 321-341. 
Maher, B.A. and Dennis, P.F., 2001. Evidence against dust-mediated control of glacialinterglacial changes in atmospheric CO2. Nature, 411(6834): 176-180.

Maher, B.A. and Hu, M.Y., 2006. A high-resolution record of Holocene rainfall variations from the western Chinese Loess Plateau: antiphase behaviour of the African/Indian and East Asian summer monsoons. Holocene, 16(3): 309-319.

Maher, B.A., Karloukovski, V., Sarah Watkins, S. and Mutch, T., 2007. New magnetic methods and data on deep-sea sediment dust fluxes, mineralogy and provenance., XVII INQUA Congress 2007, pp. http://www.icms.com.au/inqua2007/abstract/475.htm.

Maher, B.A., Mutch, T.J. and Cunningham, D., 2009. Magnetic and geochemical characteristics of Gobi Desert surface sediments: Implications for provenance of the Chinese Loess Plateau. Geology, 37(3): 279-282.

Mahowald, N., Kohfeld, K., Hansson, M., Balkanski, Y., Harrison, S.P., Prentice, I.C., Schulz, M. and Rodhe, H., 1999. Dust sources and deposition during the last glacial maximum and current climate: A comparison of model results with paleodata from ice cores and marine sediments. Journal Of Geophysical Research-Atmospheres, 104(D13): 1589515916.

Mahowald, N.M., Baker, A.R., Bergametti, G., Brooks, N., Duce, R.A., Jickells, T.D., Kubilay, N., Prospero, J.M. and Tegen, I., 2005. Atmospheric global dust cycle and iron inputs to the ocean. Global Biogeochemical Cycles, 19(4): GB4025.

Mahowald, N.M., Muhs, D.R., Levis, S., Rasch, P.J., Yoshioka, M., Zender, C.S. and Luo, C., 2006a. Change in atmospheric mineral aerosols in response to climate: Last glacial 
period, preindustrial, modern, and doubled carbon dioxide climates. Journal Of Geophysical Research-Atmospheres, 111(D10): D10202.

Mahowald, N.M., Rivera, G.D.R. and Luo, C., 2004. Comment on "Relative importance of climate and land use in determining present and future global soil dust emission" by I. Tegen et al. Geophysical Research Letters, 31(24): L24105.

Mahowald, N.M., Yoshioka, M., Collins, W.D., Conley, A.J., Fillmore, D.W. and Coleman, D.B., 2006b. Climate response and radiative forcing from mineral aerosols during the last glacial maximum, pre-industrial, current and doubled-carbon dioxide climates. Geophysical Research Letters, 33(20): L20705.

Maring, H., Savoie, D.L., Izaguirre, M.A., Custals, L. and Reid, J.S., 2003. Mineral dust aerosol size distribution change during atmospheric transport. Journal of Geophysical ResearchAtmospheres, 108(D19): D8592.

Marino, F., Castellano, E., Ceccato, D., De Deckker, P., Delmonte, B., Ghermandi, G., Maggi, V., Petit, J.R., Revel-Rolland, M. and Udisti, R., 2008. Defining the geochemical composition of the EPICA Dome $\mathrm{C}$ ice core dust during the last glacial-interglacial cycle. Geochemistry Geophysics Geosystems, 9: Q10018.

Marshall, S.J., Tarasov, L., Clarke, G.K.C. and Peltier, W.R., 2000. Glaciological reconstruction of the Laurentide Ice Sheet: physical processes and modelling challenges. Canadian Journal of Earth Sciences, 37(5): 769-793. 
Marticorena, B. and Bergametti, G., 1995. Modeling the atmospheric dust cycle .1. Design of a soil-derived dust emission scheme. Journal of Geophysical Research-Atmospheres, 100(D8): 16415-16430.

Marticorena, B., Bergametti, G., Aumont, B., Callot, Y., Ndoume, C. and Legrand, M., 1997. Modeling the atmospheric dust cycle .2. Simulation of Saharan dust sources. Journal of Geophysical Research-Atmospheres, 102(D4): 4387-4404.

Martin, J.H., 1990. Glacial-interglacial CO2 change: the iron hypothesis. Paleoceanography, 5(1): 1-13.

Martin, J.H., Gordon, R.M. and Fitzwater, S.E., 1991. The Case for Iron. Limnology and Oceanography, 36(8): 1793-1802.

Martinez-Garcia, A., Rosell-Mele, A., Geibert, W., Gersonde, R., Masque, P., Gaspari, V. and Barbante, C., 2009. Links between iron supply, marine productivity, sea surface temperature, and CO2 over the last 1.1 Ma. Paleoceanography, 24: PA1207.

Marx, S.K., Kamber, B.S. and McGowan, H., 2005a. Provenance of long-travelled dust determined with ultra-trace-element composition: a pilot study with samples from New Zealand glaciers. Earth Surface Processes and Landforms, 30(6): 699-716.

Marx, S.K., Kamber, B.S. and McGowan, H.A., 2005b. Estimates of Australian dust flux into New Zealand: Quantifying the eastern Australian dust plume pathway using trace element calibrated Pb-210 as a monitor. Earth And Planetary Science Letters, 239(3-4): 336-351. 
Mason, B.G., Pyle, D.M. and Oppenheimer, C., 2004. The size and frequency of the largest explosive eruptions on Earth. Bulletin Of Volcanology, 66(8): 735-748.

McConnell, J.R., Aristarain, A.J., Banta, J.R., Edwards, P.R. and Simoes, J.C., 2007. 20thCentury doubling in dust archived in an Antarctic Peninsula ice core parallels climate change and desertification in South America. Proceedings Of The National Academy Of Sciences Of The United States Of America, 104(14): 5743-5748.

McGee, D., Marcantonio, F. and Lynch-Stieglitz, J., 2007. Deglacial changes in dust flux in the eastern equatorial Pacific. Earth And Planetary Science Letters, 257(1-2): 215-230.

McGowan, H. and Clark, A., 2008. Identification of dust transport pathways from Lake Eyre, Australia using Hysplit. Atmospheric Environment, 42(29): 6915-6925.

McGowan, H.A., Kamber, B., McTainsh, G.H. and Marx, S.K., 2005. High resolution provenancing of long travelled dust deposited on the Southern Alps, New Zealand. Geomorphology, 69(1-4): 208-221.

McGowan, H.A., McTainsh, G.H., Zawar-Reza, P. and Sturman, A.P., 2000. Identifying regional dust transport pathways: Application of kinematic trajectory modelling to a trans-Tasman case. Earth Surface Processes and Landforms, 25(6): 633-647.

McTainsh, G., Chan, Y.C., McGowan, H., Leys, J. and Tews, K., 2005. The 23rd October 2002 dust storm in eastern Australia: characteristics and meteorological conditions. Atmospheric Environment, 39(7): 1227-1236. 
McTainsh, G.H., 1989. Quaternary Aeolian Dust Processes and Sediments in the Australian Region. Quaternary Science Reviews, 8(3): 235-253.

McTainsh, G.H. and Lynch, A.W., 1996. Quantitative estimates of the effect of climate change on dust storm activity in Australia during the Last Glacial Maximum. Geomorphology, $17(1-3): 263-271$.

Measures, C.I., Landing, W.M., Brown, M.T. and Buck, C.S., 2008. High-resolution Al and Fe data from the Atlantic Ocean CLIVAR-CO2 repeat hydrography A16N transect: Extensive linkages between atmospheric dust and upper ocean geochemistry. Global Biogeochemical Cycles, 22(1): GB1005.

Middleton, N.J., Betzer, P.R. and Bull, P.A., 2001. Long-range transport of 'giant' aeolian quartz grains: linkage with discrete sedimentary sources and implications for protective particle transfer. Marine Geology, 177(3-4): 411-417.

Miller, R.L., Cakmur, R.V., Perlwitz, J., Geogdzhayev, I.V., Ginoux, P., Koch, D., Kohfeld, K.E., Prigent, C., Ruedy, R., Schmidt, G.A. and Tegen, I., 2006. Mineral dust aerosols in the NASA Goddard institute for Space Sciences ModelE atmospheric general circulation model. Journal Of Geophysical Research-Atmospheres, 111(D6): D06208.

Miller, R.L. and Tegen, I., 1998. Climate response to soil dust aerosols. Journal of Climate, 11(12): 3247-3267.

Miller, R.L., Tegen, I. and Perlwitz, J., 2004. Surface radiative forcing by soil dust aerosols and the hydrologic cycle. Journal of Geophysical Research-Atmospheres, 109(D4): D04203. 
Mitchell, N.C. and Lyle, M.W., 2005. Patchy deposits of Cenozoic pelagic sediments in the central Pacific. Geology, 33(1): 49-52.

Moore, J.K. and Braucher, O., 2008. Sedimentary and mineral dust sources of dissolved iron to the world ocean. Biogeosciences, 5(3): 631-656.

Moore, J.K. and Doney, S.C., 2007. Iron availability limits the ocean nitrogen inventory stabilizing feedbacks between marine denitrification and nitrogen fixation. Global Biogeochemical Cycles, 21(2): GB2001.

Moore, J.K., Doney, S.C., Glover, D.M. and Fung, I.Y., 2002. Iron cycling and nutrientlimitation patterns in surface waters of the World Ocean. Deep-Sea Research Part II, 49(1-3): 463-507.

Moore, J.K., Doney, S.C. and Lindsay, K., 2004a. Upper ocean ecosystem dynamics and iron cycling in a global three-dimensional model. Global Biogeochemical Cycles, 18(4): 4028.

Moore, J.K., Doney, S.C., Lindsay, K., Mahowald, N. and Michaels, A.F., 2006. Nitrogen fixation amplifies the ocean biogeochemical response to decadal timescale variations in mineral dust deposition. Tellus Series B-Chemical and Physical Meteorology, 58(5): 560572.

Moore, K.G., Clarke, A.D., Kapustin, V.N., McNaughton, C., Anderson, B.E., Winstead, E.L., Weber, R., Ma, Y., Lee, Y.N., Talbot, R., Dibb, J., Anderson, T., Doherty, S., Covert, D. and Rogers, D., 2004b. A comparison of similar aerosol measurements made on the 
NASA P3-B, DC-8, and NSFC-130 aircraft during TRACE-P and ACE-Asia. Journal of Geophysical Research-Atmospheres, 109(D15): D15s15.

Moorthy, K.K., Babu, S.S., Satheesh, S.K., Srinivasan, J. and Dutt, C.B.S., 2007. Dust absorption over the "Great Indian Desert" inferred using ground-based and satellite remote sensing. Journal of Geophysical Research-Atmospheres, 112(D9): D09206.

Moreno, T., Querol, X., Castillo, S., Alastuey, A., Cuevas, E., Herrmann, L., Mounkaila, M., Elvira, J. and Gibbons, W., 2006. Geochemical variations in aeolian mineral particles from the Sahara-Sahel Dust Corridor. Chemosphere, 65(2): 261-270.

Moulin, C., Lambert, C.E., Dulac, F. and Dayan, U., 1997. Control of atmospheric export of dust from North Africa by the North Atlantic oscillation. Nature, 387(6634): 691-694.

Murray, R.W., Leinen, M., Murray, D.W., Mix, A.C. and Knowlton, C.W., 1995. Terrigenous Fe input and biogenic sedimentation in the glacial and interglacial equatorial Pacific Ocean. Global Biogeochemical Cycles, 9(4): 667-684.

Myhre, G., 2009. Consistency Between Satellite-Derived and Modelled Estimates of the Direct Aerosol Effect. Science, 325(5937): 187-190.

Narcisi, B., Petit, J.R., Delmonte, B., Basile-Doelsch, I. and Maggi, V., 2005. Characteristics and sources of tephra layers in the EPICA-Dome C ice record (East Antarctica): Implications for past atmospheric circulation and ice core stratigraphic correlations. Earth And Planetary Science Letters, 239(3-4): 253-265. 
Nilson, E. and Lehmkuhl, F., 1999. Interpreting temporal patterns in the late Quaternary dust flux from Asia to the North Pacific, International Conference on Loess and Palaeosols Characteristics, Stratigraphy, Chronology and Climate. Pergamon-Elsevier Science Ltd, Bonn, Germany, pp. 67-76.

Nousiainen, T., 2009. Optical modeling of mineral dust particles: A review. Journal of Quantitative Spectroscopy and Radiative Transfer, 110(14-16): 1261-1279.

Nousiainen, T., Zubko, E., Niemi, J.V., Kupiainen, K., Lehtinen, M., Muinonen, K. and Videen, G., 2009. Single-scattering modeling of thin, birefringent mineral-dust flakes using the discrete-dipole approximation. Journal of Geophysical Research-Atmospheres, 114: D07207.

Olivarez, A.M., Owen, R.M. and Rea, D.K., 1991. Geochemistry Of Eolian Dust In Pacific Pelagic Sediments - Implications For Paleoclimatic Interpretations. Geochimica Et Cosmochimica Acta, 55(8): 2147-2158.

Orgeira, M.J., Vasquez, C.A., Compagnucci, R.H., Raposo, I. and Pereyra, F.X., 2009. Rock magnetism in soils of the Pampean plain. Buenos Aires province, Argentina. Linking climate and magnetic behaviour. Revista Mexicana De Ciencias Geologicas, 26(1): 6578.

Overpeck, J., Rind, D., Lacis, A. and Healy, R., 1996. Possible role of dust-induced regional warming in abrupt climate change during the last glacial period. Nature, 384(6608): 447449. 
Park, C.B., Lee, C.H., Kim, J.H. and Ieee, 2005. Remote sensing and statistical analysis of Asian dust measured by 532/1064 nm Lidar during 2002-2005, Pacific Rim Conference on Lasers and Electro-Optics. Ieee, Tokyo, JAPAN, pp. 736-738.

Patterson, E.M. and Gillette, D.A., 1976. Measurements of visible and infrared imagery index of refraction and of size distribution for Saharan dust aerosols over Atlantic. Bulletin of the American Meteorological Society, 57(1): 146-146.

Patterson, E.M. and Gillette, D.A., 1977. Measurements of visibility vs. mass-concentration for airborne soil particles. Atmospheric Environment, 11(2): 193-196.

Paytan, A., Kastner, M. and Chavez, F.P., 1996. Glacial to interglacial fluctuations in productivity in the equatorial Pacific as indicated by marine barite. Science, 274(5291): $1355-1357$.

Paytan, A., Lyle, M., Mix, A. and Chase, Z., 2004. Climatically driven changes in oceanic processes throughout the equatorial Pacific. Paleoceanography, 19(4): PA4017.

Pedersen, T.F., 1983. Increased productivity in the eastern equatorial Pacific during the last glacial maximum (19,000 to 14,000 yr BP). Geology, 11(1): 16-19.

Peltier, W.R., 1994. Ice Age Paleotopography. Science, 265(5169): 195-201.

Peltier, W.R. and Marshall, S., 1995. Coupled energy-balance ice-sheet model simulations of the glacial cycle - a possible connection between terminations and terrigenous dust. Journal Of Geophysical Research-Atmospheres, 100(D7): 14269-14289. 
Perlwitz, J., Tegen, I. and Miller, R.L., 2001. Interactive soil dust aerosol model in the GISS GCM 1. Sensitivity of the soil dust cycle to radiative properties of soil dust aerosols. Journal Of Geophysical Research-Atmospheres, 106(D16): 18167-18192.

Perlwitz, J., and R.L. Miller, 2009. Cloud cover increase with increasing aerosol absorptivity - A counterexample to the conventional semi-direct aerosol effect. Journal Of Geophysical Research-Atmospheres, submitted.

Perry, K.D., Cahill, T.A., Eldred, R.A., Dutcher, D.D. and Gill, T.E., 1997. Long-range transport of North African dust to the eastern United States. Journal Of Geophysical ResearchAtmospheres, 102(D10): 11225-11238.

Petit, J.R., Briat, M. and Royer, A., 1981. Ice-age aerosol content from east antarctic ice core samples and past wind strength. Nature, 293(5831): 391-394.

Petit, J.R., Jouzel, J., Raynaud, D., Barkov, N.I., Barnola, J.M., Basile, I., Bender, M., Chappellaz, J., Davis, M., Delaygue, G., Delmotte, M., Kotlyakov, V.M., Legrand, M., Lipenkov, V.Y., Lorius, C., Pepin, L., Ritz, C., Saltzman, E. and Stievenard, M., 1999. Climate and atmospheric history of the past 420,000 years from the Vostok ice core, Antarctica. Nature, 399(6735): 429-436.

Piketh, S.J., Tyson, P.D. and Steffen, W., 2000. Aeolian transport from southern Africa and iron fertilization of marine biota in the South Indian Ocean. South African Journal of Science, 96(5): 244-246.

Pitty, A.F., 1968. Particle Size Of Saharan Dust Which Fell In Britain In July 1968. Nature, 220(5165): 364-365. 
Pondaven, P., Ruiz-Pino, D., Druon, J.N., Fravalo, C. and Treguer, P., 1999. Factors controlling silicon and nitrogen biogeochemical cycles in high nutrient, low chlorophyll systems (the Southern Ocean and the North Pacific): Comparison with a mesotrophic system (the North Atlantic). Deep-Sea Research Part I, 46(11): 1923-1968.

Pondaven, P., Ruiz-Pino, D., Fravalo, C., Treguer, P. and Jeandel, C., 2000. Interannual variability of Si and N cycles at the time-series station KERFIX between 1990 and 1995 A 1-D modelling study. Deep-Sea Research Part I, 47(2): 223-257.

Prins, M.A., Beets, C.J., Dijkstra, N., Vriend, M., Zheng, H.B. and Weltje, G.J., 2008. Unravelling the geologic dust record, 8th Annual V M Goldschmidt Conference. Pergamon-Elsevier Science Ltd, Vancouver, CANADA, pp. A762-A762.

Prins, M.A., Vriend, M., Nugteren, G., Vandenberghe, J., Lu, H.Y., Zheng, H.B. and Weltje, G.J., 2007. Late Quaternary aeolian dust input variability on the Chinese Loess Plateau: inferences from unmixing of loess grain-size records. Quaternary Science Reviews, 26(12): $230-242$.

Prospero, J.M., 1981. Eolian transport to the World Ocean. In: C. Emiliani (Editor), The Oceanic Lithosphere. Wiley Interscience, New York, pp. 801-874.

Prospero, J.M., 1996a. The Atmospheric Transport of Particles to the Ocean. In: V. Ittekkot, P. Schafer, S. Honjo and P.J. Depetris (Editors), Particle Flux in the Ocean. John Wiley \& Sons Ltd, New York, pp. 372. 
Prospero, J.M., 1996b. Saharan dust transport over the North Atlantic Ocean and Mediterranean: an overview. Environmental Science and Technology Library, 11(Impact of Desert Dust Across the Mediterranean): 133-151.

Prospero, J.M., 1999. Long-term measurements of the transport of African mineral dust to the southeastern United States: Implications for regional air quality. Journal Of Geophysical Research-Atmospheres, 104(D13): 15917-15927.

Prospero, J.M. and Carlson, T.N., 1972. Vertical and areal distribution of Saharan dust over western equatorial North Atlantic Ocean. Journal of Geophysical Research, 77(27): 52555265 .

Prospero, J.M., Ginoux, P., Torres, O., Nicholson, S.E. and Gill, T.E., 2002. Environmental characterization of global sources of atmospheric soil dust identified with the Nimbus 7 Total Ozone Mapping Spectrometer (TOMS) absorbing aerosol product. Reviews of Geophysics, 40(1): RG1002.

Prospero, J.M. and Lamb, P.J., 2003. African droughts and dust transport to the Caribbean: Climate change implications. Science, 302(5647): 1024-1027.

Prospero, J.M. and Nees, R.T., 1986. Impact of the North African drought and El Niño on mineral dust in the Barbados trade winds. Nature, 320(6064): 735-738.

Prospero, J.M., Uematsu, M. and Savoie, D., 1989. Mineral aerosol transport to the Pacific Ocean. In: J.P. Riley, R. Chester and R. Duce (Editors), Chemical Oceanography. Academic Press, New York, pp. 187-218. 
Pye, K., 1989. Processes of fine particle formation, dust source regions, and climatic changes. . In: M. Leinen and M. Sarnthein (Editors), Paleoclimatology and Paleometeorology: Modern and Past Patterns of Global Atmospheric Transport Kluwer Academic Pubs, Dordrecht, pp. 3-30.

Raiswell, R., Benning, L.G., Tranter, M. and Tulaczyk, S., 2008. Bioavailable iron in the Southern Ocean: the significance of the iceberg conveyor belt. Geochemical Transactions, 9: :7.

Ramsperger, B., Peinemann, N. and Stahr, K., 1998. Deposition rates and characteristics of aeolian dust in the semi-arid and sub-humid regions of the Argentinean Pampa. Journal of Arid Environments, 39(3): 467-476.

Rea, D.K., 1994. The Paleoclimatic Record Provided By Eolian Deposition In The Deep-Sea The Geologic History Of Wind. Reviews Of Geophysics, 32(2): 159-195.

Rea, D.K. and Hovan, S.A., 1995. Grain-size distribution and depositional processes of the mineral component of abyssal sediments - lessons from the North Pacific. Paleoceanography, 10(2): 251-258.

Rea, D.K., Leinen, M. and Janecek, T.R., 1985. Geologic approach to the long-term history of atmospheric circulation. Science, 227(4688): 721-725.

Reader, M.C., Fung, I. and McFarlane, N., 1999. The mineral dust aerosol cycle during the Last Glacial Maximum. Journal Of Geophysical Research-Atmospheres, 104(D8): 9381-9398. 
Reid, J.S., Jonsson, H.H., Maring, H.B., Smirnov, A., Savoie, D.L., Cliff, S.S., Reid, E.A., Livingston, J.M., Meier, M.M., Dubovik, O. and Tsay, S.C., 2003. Comparison of size and morphological measurements of coarse mode dust particles from Africa. Journal of Geophysical Research-Atmospheres, 108(D19): D8593.

Revel-Rolland, M., De Deckker, P., Delmonte, B., Hesse, P.P., Magee, J.W., Basile-Doelsch, I., Grousset, F. and Bosch, D., 2006. Eastern Australia: A possible source of dust in East Antarctica interglacial ice. Earth and Planetary Science Letters, 249(1-2): 1-13.

Ridgwell, A.J., 2002. Dust in the Earth system: the biogeochemical linking of land, air and sea. Philosophical Transactions Of The Royal Society Of London Series A-Mathematical Physical And Engineering Sciences, 360(1801): 2905-2924.

Ridgwell, A.J. and Watson, A.J., 2002. Feedback between aeolian dust, climate, and atmospheric CO2 in glacial time. Paleoceanography, 17(4): PA1059.

Roberts, H.M., 2008. The development and application of luminescence dating to loess deposits: a perspective on the past, present and future. Boreas, 37(4): 483-507.

Roberts, H.M. and Duller, G.A.T., 2004. Standardised growth curves for optical dating of sediment using multiple-grain aliquots. Radiation Measurements, 38(2): 241-252.

Rothlisberger, R., Bigler, M., Wolff, E.W., Joos, F., Monnin, E. and Hutterli, M.A., 2004. Ice core evidence for the extent of past atmospheric $\mathrm{CO} 2$ change due to iron fertilisation. Geophysical Research Letters, 31(16): L16207. 
Rothlisberger, R., Mulvaney, R., Wolff, E.W., Hutterli, M.A., Bigler, M., Sommer, S. and Jouzel, J., 2002. Dust and sea salt variability in central East Antarctica (Dome C) over the last 45 kyrs and its implications for southern high-latitude climate. Geophysical Research Letters, 29(20): L1963.

Rousseau, D.D., Antoine, P., Hatte, C., Lang, A., Zoller, L., Fontugne, M., Ben Othman, D., Luck, J.M., Moine, O., Labonne, M., Bentaleb, I. and Jolly, D., 2002. Abrupt millennial climatic changes from Nussloch (Germany) Upper Weichselian eolian records during the Last Glaciation. Quaternary Science Reviews, 21(14-15): 1577-1582.

Ruth, U., 2005. Mineral dust records from Greenland ice cores, PAGES newsletter (invited contribution). PAGES International Project Office, Bernn., pp. 17-18.

Ruth, U., Wagenbach, D., Steffensen, J.P. and Bigler, M., 2003. Continuous record of microparticle concentration and size distribution in the central Greenland NGRIP ice core during the last glacial period. Journal Of Geophysical Research-Atmospheres, 108(D3): D4098.

Sarthou, G., Baker, A.R., Blain, S., Achterberg, E.P., Boye, M., Bowie, A.R., Croot, P., Laan, P., de Baar, H.J.W., Jickells, T.D. and Worsfold, P.J., 2003. Atmospheric iron deposition and sea-surface dissolved iron concentrations in the eastern Atlantic Ocean. Deep-Sea Research Part I, 50(10-11): 1339-1352.

Sassen, K., DeMott, P. J., Prospero, J.M. and Poellot, M.R.. 2003. Saharan dust storms and indirect aerosol effects on clouds: CRYSTAL-FACE results, Geophysical Research Letters, 30(12), 1633. 
Schellenberger, A. and Veit, H., 2006. Pedostratigraphy and pedological and geochemical characterization of Las Carreras loess-paleosol sequence, Valle de Tafi, NW-Argentina. Quaternary Science Reviews, 25(7-8): 811-831.

Schroth, A.W., Crusius, J., Sholkovitz, E.R. and Bostick, B.C., 2009. Iron solubility driven by speciation in dust sources to the ocean. Nature Geoscience, 2(5): 337-340.

Schutz, L. and Jaenicke, R., 1974. Particle number and mass distributions above 10-4 cm radius in sand and aerosol of Sahara desert. Journal of Applied Meteorology, 13(8): 863-870.

Schwertmann, U. and Taylor, R.M., 1987. Iron oxides. In: J.B. Dixon and S.B. Weed (Editors), Minerals in Soil Environments, $2^{\text {nd }}$ ed. Soil Science Society of America, Madison.

Schwertmann, U.C., R.M, 1991. Iron Oxides in the Laboratory: Preparation and Characterization. VCH, Weinheim, 137 pp.

Sedwick, P., Sholkovitz, E.R. and Church, T., 2007. Impact of anthropogenic combustion emissions on the fractional solubility of aerosol iron: Evidence from the Sargasso Sea. Geochemistry Geophysics Geosystems, 8(10): Q10Q06.

Sedwick, P.N., Bowie, A.R. and Trull, T.W., 2008. Dissolved iron in the Australian sector of the Southern Ocean (CLIVAR SR3 section): Meridional and seasonal trends. Deep-Sea Research Part I-Oceanographic Research Papers, 55(8): 911-925.

Sedwick, P.N., Church, T.M., Bowie, A.R., Marsay, C.M., Ussher, S.J., Achilles, K.M., Lethaby, P.J., Johnson, R.J., Sarin, M.M. and McGillicuddy, D.J., 2005. Iron in the Sargasso Sea (Bermuda Atlantic Time-series Study region) during summer: Eolian imprint, 
spatiotemporal variability, and ecological implications. Global Biogeochemical Cycles, 19(4): GB4006.

Shao, Y. and Raupach, M.R., 1993. Effect of saltation bombardment on the entrainment of dust by wind. Journal Of Geophysical Research-Atmospheres, 98(D7): 12719-12726.

Shao, Y.P., Leys, J.F., McTainsh, G.H. and Tews, K., 2007. Numerical simulation of the October 2002 dust event in Australia. Journal Of Geophysical Research-Atmospheres, 112: D08207.

Shaw, E.C., Gabric, A.J. and McTainsh, G.H., 2008. Impacts of aeolian dust deposition on phytoplankton dynamics in Queensland coastal waters. Marine and Freshwater Research, 59(11): 951-962.

$\underline{\text { Schepanski, K., I. Tegen, M. C. Todd, B. Heinold, G. Bönisch, B. Laurent, and A. Macke, }}$ 2009. Meteorological processes forcing Saharan dust emission inferred from MSGSEVIRI observations of subdaily dust source activation and numerical models, J. Geophys. Res., 114, D10201, doi:10.1029/2008JD010325.

Schepanski, K., I. Tegen, B. Laurent, B. Heinold, and A. Macke, 2007. A new Saharan dust source activation frequency map derived from MSG-SEVIRI IRchannels, Geophys. Res. Lett., 34, L18803, doi:10.1029/2007GL030168.

Formatted: Font: Times New Roman, $12 \mathrm{pt}$
Formatted: Font: Times New Roman, $12 \mathrm{pt}$
Formatted: Font: Times New Roman, $12 \mathrm{pt}$
Formatted: Font: Times New Roman, $12 \mathrm{pt}$
Formatted: Font: Times New Roman, $12 \mathrm{pt}$

Shigemitsu, M., Narita, H., Watanabe, Y.W., Harada, N. and Tsunogai, S., 2007. Ba, Si, U, Al, Sc, La, Th, C and C-13/C-12 in a sediment core in the western subarctic Pacific as proxies of past biological production. Marine Chemistry, 106(3-4): 442-455. 
Shin, S.I., Liu, Z., Otto-Bliesner, B., Brady, E.C., Kutzbach, J.E. and Harrison, S.P., 2003. A simulation of the last glacial maximum climate using the NCAR-CCSM. Climate Dynamics, 20(2-3): 127-151.

Siegenthaler, U., Monnin, E., Kawamura, K., Spahni, R., Schwander, J., Stauffer, B., Stocker, T.F., Barnola, J.M. and Fischer, H., 2005. Supporting evidence from the EPICA Dronning Maud Land ice core for atmospheric CO2 changes during the past millennium. Tellus Series B-Chemical and Physical Meteorology, 57(1): 51-57.

Sokolik, I.N. and Toon, O.B., 1996. Direct radiative forcing by anthropogenic airborne mineral aerosols. Nature, 381(6584): 681-683.

Sokolik, I.N. and Toon, O.B., 1999. Incorporation of mineralogical composition into models of the radiative properties of mineral aerosol from UV to IR wavelengths. Journal of Geophysical Research-Atmospheres, 104(D8): 9423-9444.

Sow, M., Alfaro, S.C., Rajot, J.L. and Marticorena, B., 2009. Size resolved dust emission fluxes measured in Niger during 3 dust storms of the AMMA experiment. Atmospheric Chemistry and Physics, 9(12): 3881-3891.

Spokes, L.J., Jickells, T.D. and Lim, B., 1994. Solubilization of Aerosol Trace-Metals by Cloud Processing - a Laboratory Study. Geochimica Et Cosmochimica Acta, 58(15): 32813287.

Spracklen, D.V., Carslaw, K.S., Kulmala, M., Kerminen, V.M., Sihto, S.L., Riipinen, I., Merikanto, J., Mann, G.W., Chipperfield, M.P., Wiedensohler, A., Birmili, W. and 
Lihavainen, H., 2008. Contribution of particle formation to global cloud condensation nuclei concentrations. Geophysical Research Letters, 35(6): 5.

Stancin, A.M., Gleason, J.D., Hovan, S.A., Rea, D.K., Owen, R.M., Moore, T.C., Hall, C.M. and Blum, J.D., 2008. Miocene to recent eolian dust record from the Southwest Pacific Ocean at 40 degrees S latitude. Palaeogeography Palaeoclimatology Palaeoecology, 261(3-4): 218-233.

Stancin, A.M., Gleason, J.D., Rea, D.K., Owen, R.M., Moore, T.C., Blum, J.D. and Hovan, S.A., 2006. Radiogenic isotopic mapping of late Cenozoic eolian and hernipelagic sediment distribution in the east-central Pacific. Earth And Planetary Science Letters, 248(3-4): 840-850.

Steffensen, J.P., 1985. Microparticles in snow from the South Greenland Ice Sheet. Tellus Series B-Chemical and Physical Meteorology, 37(4-5): 286-295.

Steffensen, J.P., 1997. The size distribution of microparticles from selected segments of the Greenland Ice Core Project ice core representing different climatic periods. Journal of Geophysical Research-Oceans, 102(C12): 26755-26763.

Stuut, J.B.W. and Lamy, F., 2004. Climate variability at the southern boundaries of the Namib (Southwestern Africa) and Atacama (northern Chile) coastal deserts during the last 120,000 yr. Quaternary Research, 62(3): 301-309.

Sugden, D.E., McCulloch, R.D., Bory, A.J.M. and Hein, A.S., 2009. Influence of Patagonian glaciers on Antarctic dust deposition during the last glacial period. Nature Geoscience, 2(4): 281-285. 
Summerell, G.K., Dowling, T.I., Richardson, D.P., Walker, J. and Lees, B., 2000. Modelling current parna distribution in a local area. Australian Journal of Soil Research, 38(4): 867878.

Sun, Y.B., Tada, R.J., Chen, J.C., Liu, Q.S., Toyoda, S., Tani, A., Ji, J.F. and Isozaki, Y., 2008. Tracing the provenance of fine-grained dust deposited on the central Chinese Loess Plateau. Geophysical Research Letters, 35(1): L01804.

Svensson, A., Biscaye, P.E. and Grousset, F.E., 2000. Characterization of late glacial continental dust in the Greenland Ice Core Project ice core. Journal Of Geophysical ResearchAtmospheres, 105(D4): 4637-4656.

Sviridenkov, M.A., Gillette, D.A., Isakov, A.A., Sokolik, I.N., Smirnov, V.V., Belan, B.D., Pachenko, M.V., Andronova, A.V., Kolomiets, S.M., Zhukov, V.M. and Zhukovsky, D.A., 1993. Size distributions of dust aerosol measured during the Soviet-American experiment in Tajikistan, 1989. Atmospheric Environment Part a-General Topics, 27(16): 2481-2486.

Swap, R., Garstang, M., Greco, S., Talbot, R. and Kallberg, P., 1992. Saharan Dust in the Amazon Basin. Tellus Series B: Chemical and Physical Meteorology, 44(2): 133-149.

Tagliabue, A., Bopp, L. and Aumont, O., 2009. Evaluating the importance of atmospheric and sedimentary iron sources to Southern Ocean biogeochemistry. Geophysical Research Letters, 36: L13601.

Tanaka, T.Y. and Chiba, M., 2006. A numerical study of the contributions of dust source regions to the global dust budget. Global And Planetary Change, 52(1-4): 88-104. 
Taylor, R.M., McKenzie, R.M., Fordham, A.W. and Gillman, G.P., 1983. Oxide minerals. In: A.E. Martin (Editor), Soils: an Australian viewpoint. CSIRO/Acadeimc Press, Melbourne/London, pp. 309-334.

Tegen, I. and Fung, I., 1995. Contribution To The Atmospheric Mineral Aerosol Load From Land-Surface Modification. Journal Of Geophysical Research-Atmospheres, 100(D9): 18707-18726.

Tegen, I., Harrison, S.P., Kohfeld, K., Prentice, I.C., Coe, M. and Heimann, M., 2002. Impact of vegetation and preferential source areas on global dust aerosol: Results from a model study. Journal Of Geophysical Research-Atmospheres, 107(D21): D4576.

Tegen, I., Werner, M., Harrison, S.P. and Kohfeld, K.E., 2004. Relative importance of climate and land use in determining present and future global soil dust emission. Geophysical Research Letters, 31(5): L05105.

Textor, C., Schulz, M., Guibert, S., Kinne, S., Balkanski, Y., Bauer, S., Berntsen, T., Berglen, T., Boucher, O., Chin, M., Dentener, F., Diehl, T., Easter, R., Feichter, H., Fillmore, D., Ghan, S., Ginoux, P., Gong, S., Kristjansson, J.E., Krol, M., Lauer, A., Lamarque, J.F., Liu, X., Montanaro, V., Myhre, G., Penner, J., Pitari, G., Reddy, S., Seland, O., Stier, P., Takemura, T. and Tie, X., 2006. Analysis and quantification of the diversities of aerosol life cycles within AeroCom. Atmospheric Chemistry and Physics, 6: 1777-1813.

Thompson, R. and Maher, B.A., 1995. Age models, sediment fluxes and paleoclimatic reconstructions for the Chinese loess and paleosol sequences. Geophysical Journal International, 123(2): 611-622. 
Toggweiler, J.R., Russell, J.L. and Carson, S.R., 2006. Midlatitude westerlies, atmospheric CO2, and climate change during the ice ages. Paleoceanography, 21(2).

Torii, M., Lee, T.Q., Fukuma, K., Mishima, T., Yamazaki, T., Oda, H. and Ishikawa, N., 2001. Mineral magnetic study of the Taklimakan desert sands and its relevance to the Chinese loess. Geophysical Journal International, 146(2): 416-424.

Tsuda, A., Takeda, S., Saito, H., Nishioka, J., Nojiri, Y., Kudo, I., Kiyosawa, H., Shiomoto, A., Imai, K., Ono, T., Shimamoto, A., Tsumune, D., Yoshimura, T., Aono, T., Hinuma, A., Kinugasa, M., Suzuki, K., Sohrin, Y., Noiri, Y., Tani, H., Deguchi, Y., Tsurushima, N., Ogawa, H., Fukami, K., Kuma, K. and Saino, T., 2003. A mesoscale iron enrichment in the western Subarctic Pacific induces a large centric diatom bloom. Science, 300(5621): 958-961.

Uematsu, M., Duce, R.A., Prospero, J.M., Chen, L., Merrill, J.T. and McDonald, R.L., 1983. Transport of mineral aerosol from Asia over the north Pacific Ocean. Journal of Geophysical Research-Oceans and Atmospheres, 88(NC9): 5343-5352.

Uematsu, M., Wang, Z.F. and Uno, I., 2003. Atmospheric input of mineral dust to the western North Pacific region based on direct measurements and a regional chemical transport model. Geophysical Research Letters, 30(6): L1342.

VanCuren, R.A. and Cahill, T.A., 2002. Asian aerosols in North America: Frequency and concentration of fine dust. Journal of Geophysical Research-Atmospheres, 107(D24): D4804. 
Visser, F., Gerringa, L.J.A., Van der Gaast, S.J., de Baar, H.J.W. and Timmermans, K.R., 2003. The role of the reactivity and content of iron of aerosol dust on growth rates of two Antarctic diatom species. Journal of Phycology, 39(6): 1085-1094.

Wagenbach, D. and Geis, K., 1987. The mineral dust record in a high-altitude alpine glacier (Colle-Gnifetti, Swiss Alps). In: M. Leinen and M. Sarnthein (Editors), Nato Advanced Research Workshop on Paleoclimatology and Paleometeorology : Modern and Past Patterns of Global Atmospheric Transport. Kluwer Academic Publ, Oracle, Az, pp. 543564.

Wagener, T., Losno, R., Bonnet, S. and Mahowald, N., 2008. Revisiting atmospheric dust export to the South Hemisphere ocean. Global Biogeochemical Cycles, 22(2): GB2006.

Wake, C.P., Mayewski, P.A., Li, Z., Han, J. and Qin, D., 1994. Modern eolian dust deposition in Central-Asia. Tellus Series B-Chemical and Physical Meteorology, 46(3): 220-233.

Walter, H.J., Hegner, E., Diekmann, B., Kuhn, G. and van der Loeff, M.M.R., 2000. Provenance and transport of terrigenous sediment in the South Atlantic Ocean and their relations to glacial and interglacial cycles: $\mathrm{Nd}$ and $\mathrm{Sr}$ isotopic evidence. Geochimica Et Cosmochimica Acta, 64(22): 3813-3827.

Wang, H., Mason, J.A. and Balsam, W.L., 2006a. The importance of both geological and pedological processes in control of grain size and sedimentation rates in Peoria Loess. Geoderma, 136(1-2): 388-400.

Wang, T., Ta, W.Q. and Liu, L.C., 2007. Dust emission from desertified lands in the Heihe River Basin, Northwest China. Environmental Geology, 51(8): 1341-1347. 
Wang, X.M., Zhou, Z.J. and Dong, Z.B., 2006b. Control of dust emissions by geomorphic conditions, wind environments and land use in northern China: An examination based on dust storm frequency from 1960 to 2003. Geomorphology, 81(3-4): 292-308.

Wang, Y.Q., Zhang, X.Y. and Arimoto, R., 2006c. The contribution from distant dust sources to the atmospheric particulate matter loadings at XiAn, China during spring. Science of the Total Environment, 368(2-3): 875-883.

Warren, A., Chappell, A., Todd, M. C., Bristow, C., Drake, N., Engelstaedter, S., Martins, V., M'bainayel, S. and Washington, R., 2007. Dust-raising in the dustiest place on earth, Geomorphology, 92, 25-37.

Washington, R., Todd, M., Middleton, N.J. and Goudie, A.S., 2003. Dust-storm source areas determined by the total ozone monitoring spectrometer and surface observations. Annals Of The Association Of American Geographers, 93(2): 297-313.

Washington, R. and Todd, M.C., 2005. Atmospheric controls on mineral dust emission from the Bodele Depression, Chad: The role of the low level jet. Geophysical Research Letters, 32(17): L17701.

Washington, R., Todd, M.C., Lizcano, G., Tegen, I., Flamant, C., Koren, I., Ginoux, P., Engelstaedter, S., Bristow, C.S., Zender, C.S., Goudie, A.S., Warren, A. and Prospero, J.M., 2006. Links between topography, wind, deflation, lakes and dust: The case of the Bodele Depression, Chad. Geophysical Research Letters, 33(9): L09401. 
Watkins, S.J., Maher, B.A. and Bigg, G.R., 2007. Ocean circulation at the Last Glacial Maximum: A combined modeling and magnetic proxy-based study. Paleoceanography, 22(2): PA2204.

Watson, A.J., Bakker, D.C.E., Ridgwell, A.J., Boyd, P.W. and Law, C.S., 2000. Effect of iron supply on Southern Ocean $\mathrm{CO} 2$ uptake and implications for glacial atmospheric $\mathrm{CO} 2$. Nature, 407(6805): 730-733.

Watson, A.J. and Garabato, A.C.N., 2006. The role of Southern Ocean mixing and upwelling in glacial-interglacial atmospheric CO2 change. Tellus Series B-Chemical and Physical Meteorology, 58(1): 73-87.

Werner, M., Tegen, I., Harrison, S.P., Kohfeld, K.E., Prentice, I.C., Balkanski, Y., Rodhe, H. and Roelandt, C., 2002. Seasonal and interannual variability of the mineral dust cycle under present and glacial climate conditions. Journal of Geophysical Research-Atmospheres, 107(D24): 4744.

Williams, E.R., 2008. Comment on "Atmospheric controls on the annual cycle of North African dust" by S. Engelstaedter and R. Washington. Journal of Geophysical ResearchAtmospheres, 113(D23): D23109.

Winckler, G., Anderson, R.F., McGee, D., Fleisher, M.Q. and Mahowald, N., 2008. Half a million years of coherent dust flux variations in the tropical Pacific and Antarctica, 8th Annual V M Goldschmidt Conference. Pergamon-Elsevier Science Ltd, Vancouver, CANADA, pp. A1026-A1026. 
Wolff, E.W., Fischer, H., Fundel, F., Ruth, U., Twarloh, B., Littot, G.C., Mulvaney, R., Rothlisberger, R., de Angelis, M., Boutron, C.F., Hansson, M., Jonsell, U., Hutterli, M.A., Lambert, F., Kaufmann, P., Stauffer, B., Stocker, T.F., Steffensen, J.P., Bigler, M., Siggaard-Andersen, M.L., Udisti, R., Becagli, S., Castellano, E., Severi, M., Wagenbach, D., Barbante, C., Gabrielli, P. and Gaspari, V., 2006. Southern Ocean sea-ice extent, productivity and iron flux over the past eight glacial cycles. Nature, 440(7083): 491-496.

Xiao, J., Porter, S.C., An, Z.S., Kumai, H. and Yoshikawa, S., 1995. Grain-size of quartz as an indicator of winter monsoon strength on the loess plateau of central China during the last 130,000-yr. Quaternary Research, 43(1): 22-29.

Xiao, J.L., An, Z.S., Liu, T.S., Inouchi, Y., Kumai, H., Yoshikawa, S. and Kondo, Y., 1999. East Asian monsoon variation during the last 130,000 Years: evidence from the Loess Plateau of central China and Lake Biwa of Japan. Quaternary Science Reviews, 18(1): 147-157.

Yoshioka, M., Mahowald, N., Dufresne, J.L. and Luo, C., 2005. Simulation of absorbing aerosol indices for African dust. Journal Of Geophysical Research-Atmospheres, 110(D18): 22.

Yung, Y.L., Lee, T., Wang, C.H. and Shieh, Y.T. 1996. Dust: A diagnostic of the hydrologic cycle during the Last Glacial Maximum. Science, 271, 962-963, DOI:10.1126/ science. 271.5251 .962 .

Zarate, M.A., 2003. Loess of southern South America. Quaternary Science Reviews, 22(18-19): 1987-2006 
Zender, C.S., Bian, H.S. and Newman, D., 2003. Mineral Dust Entrainment and Deposition (DEAD) model: Description and 1990s dust climatology. Journal of Geophysical Research-Atmospheres, 108(D14): D4416.

Zender, C.S., Miller, R.L. and Tegen, I., 2005. Quantifying Mineral Dust Mass Budgets: Terminology, Constraints, and Current Estimates. Eos, 85(48): 509-512.

Zhang, D.Z. and Iwasaka, Y., 2004. Size change of Asian dust particles caused by sea salt interaction: Measurements in southwestern Japan. Geophysical Research Letters, 31(15): L15102.

Zhang, J.Y., Wang, P.X., Li, Q.Y., Cheng, X.R., Jin, H.Y. and Zhang, S.Y., 2007. Western equatorial Pacific productivity and carbonate dissolution over the last $550 \mathrm{kyr}$ : Foraminiferal and nannofossil evidence from ODP Hole 807A. Marine Micropaleontology, 64(3-4): 121-140.

Zhang, X.Y., Arimoto, R. and An, Z.S., 1999. Glacial and interglacial patterns for Asian dust transport. Quaternary Science Reviews, 18(6): 811-819.

Zhang, X.Y., Lu, H.Y., Arimoto, R. and Gong, S.L., 2002. Atmospheric dust loadings and their relationship to rapid oscillations of the Asian winter monsoon climate: two 250-kyr loess records. Earth And Planetary Science Letters, 202(3-4): 637-643.

Zhao, T.L., Gong, S.L., Zhang, X.Y. and McKendry, I.G., 2003. Modelled size-segregated wet and dry deposition budgets of soil dust aerosol during ACE-Asia 2001: Implications for trans-Pacific transport. Journal of Geophysical Research-Atmospheres, 108(D23): 8665. 
2701

2702

2703

2704

2705

2706

2707

2708

2709

2710

2711

2712

2713

2714

Zhu, A., Ramanathan, V., Li, F. and Kim, D., 2007. Dust plumes over the Pacific, Indian, and Atlantic oceans: Climatology and radiative impact. Journal Of Geophysical ResearchAtmospheres, 112(D16): 20.

Ziegler, C.L., Murray, R.W., Hovan, S.A. and Rea, D.K., 2007. Resolving eolian, volcanogenic, and authigenic components in pelagic sediment from the Pacific Ocean. Earth and Planetary Science Letters, 254(3-4): 416-432.

Ziegler, C.L., Murray, R.W., Plank, T. and Hemming, S.R., 2008. Sources of Fe to the equatorial Pacific Ocean from the Holocene to Miocene. Earth and Planetary Science Letters, 270(3-4): 258-270.

Zielinski, G.A., Mayewski, P.A., Meeker, L.D., Whitlow, S. and Twickler, M.S., 1996. A 110,000-yr record of explosive volcanism from the GISP2 (Greenland) ice core. Quaternary Research, 45(2): 109-118. 
Figure 1. Schematic of the hypothetical glacial dust-atmospheric $\mathrm{CO}_{2}$-climate feedback system. Different components of the Earth system can directly interact in three possible ways: positive influences (an increase in one component resulting directly in an increase in a second component) are indicated by red arrows; negative influences are indicated by black arrows; or no influence.. An even number (including zero) of negative influences within any given closed loop give rise to a positive feedback, operation of which tends to amplify any initial perturbation (e.g. the ice-albedo feedback). An odd number of negative influences gives rise to a negative feedback, which tends to dampen any perturbation. Primary interactions are indicated by solid lines, additional interactions dotted lines. Four main (positive) dust-atmospheric $\mathrm{CO}_{2}$-climate feedback loops exist in this system. 1. Dust supply $\rightarrow$ ocean export production $\rightarrow \mathrm{xCO}_{2} \rightarrow$ temperature $\rightarrow$ ice volume $\rightarrow$ sea level $\rightarrow$ dust supply (four negative interactions). 2. Dust supply $\rightarrow$ ocean export production $\rightarrow \mathrm{xCO}_{2} \rightarrow$ temperature $\rightarrow$ hydrological cycle $\rightarrow$ vegetation $\rightarrow$ dust supply (two negative interactions). 3. Dust supply $\rightarrow$ ocean export production $\rightarrow \mathrm{xCO}_{2}$ $\rightarrow$ temperature $\rightarrow$ hydrological cycle $\rightarrow$ dust supply (two negative interactions). 4 . Dust supply $\rightarrow$ ocean export production $\rightarrow \mathrm{xCO}_{2} \rightarrow$ temperature $\rightarrow$ ice volume $\rightarrow$ dust supply (two negative interactions). From Ridgwell, 2002.

Figure 2. Dust deflation and entrainment processes (modified from Pye, 1987).

Figure 3. a) Remotely sensed aerosol optical depth measurements (Husar et al., 1997); b) The global distribution of major dust sources and dust transport paths based on the Total Ozone Mapping Satellite (TOMS) absorbing aerosol index (AAI) (Prospero et al., 2002). The figure is a composite of monthly mean TOMS AAI frequency of occurrence distributions computed using a threshold of 1.0 in the North Africa - Middle East - Asian dust belt and 0.7 everywhere else. The arrows show the main transport paths over the oceans. The arrow size is not indicative of the magnitude of the transport nor the distance that dust is carried. Some major points of note:

During the late boreal spring, summer and fall, huge quantities of African dust are carried to the western Atlantic and into the Caribbean and the eastern United States; also, from sources in the Arabian Peninsula and southwest Asia to the Arabian Sea and Indian Ocean. Dust is also carried across the Mediterranean to Europe and the Middle East.

Over the Atlantic during the boreal winter and early spring, dust from the Sahara and the Sahel is carried to South America; large quantities are also carried on occasion to the midlatitude Atlantic and into Europe, as indicated by the north-looping arrow.

The large arrow in the North Pacific shows the main direction of large dust storms carried from Asia every boreal spring, in some cases penetrating to North America; the dust originates from a variety of sources including arid regions in Inner Mongolia (cross-hatched area) which do not show up well in the TOMS product.

The dust sources in the Southern Hemisphere are considerably smaller and less active than those in the Northern Hemisphere. The most active are those in Argentina, southern Africa and Australia.

Figure 4. a) Normalised size distributions of dust measured on Tenerife, Canary Islands (July, 1995) and in Puerto Rico (July, 2000) using the identical instrument, a TSI APS 3310. The Tenerife site is $\sim 300 \mathrm{~km}$ from the N. African coast while Puerto Rico is $5000 \mathrm{~km}$ to the west. 
The transit time for dust outbreaks is about 5 - 7 days; b) wind tunnel data (Alfaro et al., 1997) indicating smaller modal particle sizes entrained and transported at higher wind speeds.

Figure 5. Effect of the mass median diameter on dust deposition flux and on optical depth of the particle size distribution. Optical depth expresses the amount of radiation removed by scattering or absorption. Values are normalized to a size distribution with a mass median diameter of 4.5 $\mu \mathrm{m}$ and a sigma value of 2.1 (Reid et al., 2003, Table 1). A log-normal distribution with a constant width is assumed (Balkanski et al., 2007).

Figure 6. Transmission electron micrographs of discrete, pedogenic 'free iron' grains, a) typically acicular particles of goethite $(\alpha \mathrm{FeOOH})$, scale bar $=200 \mathrm{~nm}, \mathrm{~b})$ more equidimensional particles of haematite $\left(\alpha \mathrm{Fe}_{2} \mathrm{O}_{3}\right)$ - the smaller, electron-opaque particles -, essentially unassociated with the larger, clean flakes of kaolinite, scale bar $=1 \mu \mathrm{m}$; c) ultrafine haematite crystallite, soil sample, Morocco, scale bar $=100 \mathrm{~nm}$. Micrographs from Maher et al. (2003), Jones (in Schwertmann, 1991), and Lieke (pers. comm.), respectively.

Figure 7. a) Atmospheric warming from absorption of radiation by dust; b) resultant net surface cooling. Integration of satellite and ground-based data for 2002 (from Chung et al., 2005).

Figure 8. Changes in glacial/interglacial dust concentrations over a pole-to-pole transect, spanning Greenland (the NGRIP ice core record, dust mass, ppm/10, Ruth, 2005, Svensson et al., 2000), the northern North Atlantic (Core T88, $48.3^{\circ} \mathrm{N}, 25.0^{\circ} \mathrm{W}$, high-field magnetic dust proxy, Maher, unpub. data), equatorial Atlantic (ODP Site $633 \mathrm{~A}, 1.28{ }^{\circ} \mathrm{N}, 11.98^{\circ} \mathrm{W}$, terrigenous $\%$, deMenocal et al., 1993) and Antarctica (EPICA Dome C, dust mass, EPICA Community members, 2004)

Figure 9. a) Measured aeolian MARs for the present day (for MAR data, see Appendix 1, and for MARs, age, site and quality control data, see the updated 'DIRTMAP3' database (Maher and Kohfeld, 2009, http://www.lec.lancs.ac.uk/research/LU themes/inqua working group.php); b) modelled LGM MARs (Mahowald et al., 2006).

Figure 10. a) Measured aeolian MARs for the LGM (for MAR data, see Appendix 1, and for MARs, age, site and quality control data, see the updated 'DIRTMAP3' database (Maher and Kohfeld, 2009, http://www.lec.lancs.ac.uk/research/LU themes/inqua working group.php); b) modelled LGM MARs (Mahowald et al., 2006 and Mahowald, pers. comm).

Figure 11. Typically trimodal particle size distribution of Chinese loess (Wang et al., 2007).

Figure 12. Time series of North Greenland Ice core Project (NGRIP) and Chinese loess data, synchronized on the NGRIP SS09 age scale (Ruth et al., 2003). Ice core data: $\delta^{18} \mathrm{O}$, dust mass and mean particle size (diameter, lognormal mode of volume distribution); loess data: quartz mean diameter, from the central Loess Plateau site, Luochuan (Xiao et al., 1999).

Figure 13. Particle size records for the mid-latitude Pacific over several glacial-interglacial stages (redrawn from Hovan et al., 1991 and Zhang et al., 2007; 'v' in panel 3 = volcanic ash). 
Figure 14. Time series of dust flux to the central equatorial Pacific (TTN013-PC72; $0.1^{\circ} \mathrm{N}$, $139.4^{\circ} \mathrm{W}$ ) and to the EPICA Dome C Antarctic ice core (from Winckler et al., 2008).

Figure 15. Dust fluxes at the Vostok and EPICA Dome C Antarctic ice cores (redrawn from Lambert et al., 2008).

Figure 16. The sectors of the Southern Ocean, together with the frontal system of the Antarctic Circumpolar Current, and the locations of the deep sea sediment and Antarctic ice cores referred to here (modified from Diekmann, 2007).

Figure 17. Isotopic characterization ( $\mathrm{Nd}: \mathrm{Sr})$ of Antarctic dusts and suite of potential source areas, a) as reported for $<5 \mu \mathrm{m}$ potential source samples (Delmonte et al., 2004), and b) a refinement of plot a; progress definition of the Patagonian isotopic signature and inclusion of new samples from Australia (Revel-Rolland et al., 2006) and the Puna/Altiplano of South America (Gaiero, 2007; Delmonte et al., 2009) to explain the non-Patagonian isotopic signature found in the Antarctic dust.

Figure 18. Comparison of the Southern Ocean and Antarctic ice core records over the last 1.1Ma. (a) Temperature reconstruction from EPICA ice cores (black) (Jouzel et al., 2007) and alkenonebased SST from site PS2489-2/ODP1090 (red). Marine Isotope Stages (MIS) are shown for reference. (b) Atmospheric $\mathrm{CO}_{2}$ concentrations from the EPICA ice cores. Dashed line indicates the $\mathrm{CO}_{2}$ level when productivity starts to increase above the average interglacial value. Filled area illustrates $\mathrm{CO}_{2}$ concentrations below $230 \mathrm{ppmv}$. Glacial terminations are shown for reference. (c) EPICA Fe flux (blue) and site PS2489-2/ODP1090 Fe flux (red). (d) EPICA Insoluble dust (light brown) and site PS2489-2/ODP1090 long-chain odd carbon-numbered nalkanes (C25-35) mass accumulation rate (MAR) (blue). (e) Site PS2489-2/ODP1090 C37 alkenones MAR (green) and TOC MAR (Diekmann and Kuhn, 2002) (black). Shaded areas highlight the high-productivity intervals, when alkenone MARs are $3 \mathrm{x}$ the average interglacial value. (Redrawn from Martinez-Garcia et al., 2009).

Figure 19. Time series of proxy records for palaeo-productivity and dust flux for the equatorial Pacific through several glacial-interglacial cycles (Redrawn from Anderson et al., 2008).

Figure 20. ${ }^{230} \mathrm{Th}$-normalised fluxes of biogenic opal in the three sectors of the Southern Ocean (from Diekmann, 2007).

Figure 21. a) Global $\delta^{18} \mathrm{O}$ stack(Lisiecki \& Raymo, 2005) versus n-alkanes concentrations from Southern Ocean site PS2489-2/ODP1090; marine isotope stages shown; b) Temperature reconstruction from EPICA ice cores (Jouzel et al., 2007) and alkenone-based SSTs from PS2489-2/ODP1090; c) atmospheric $\mathrm{CO}_{2}$ concentration from the EPICA ice cores (Luthi et al., 2008; Petit et al., 1999; Siegenthaler et al., 2005) versus alkenones concentration, PS24892/ODP1090.

Figure 22. Schematic of the sources, process and impacts of dust on climate, a) at the present day, and b) at the LGM, with key gaps in data and understanding marked by '?' on the diagrams. 
2851 Table captions.

2852

2853 Table 1. Comparison of a range of modelled present day dust fluxes (mean annual, by region).

2854 The unit is $\mathrm{Tg} / \mathrm{yr}$, numbers in brackets $=$ the $\%$ of the annual mean global emission flux. (From

2855 Tanaka \& Chiba, 2006).

2856

2857

2858

2859 